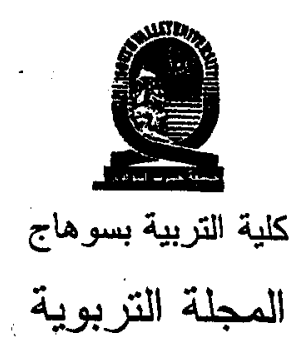

\title{
أثر تدريب معلى الدراسات الاجتماعية بالمرحلة الإعدادية على استخدام نموذجين تعليميين في أدائهم التدريس وميولهم نحو تدريس الدراسات الاجتماعية
}

إعداد

دكتور/ أحمد جابر أحمد السبد

الأستاذ المساعد بكلية التربية

بسوهاج

الجلة الزبوية - العدد الحامس عشر - يناير .... Pم 


\title{
- 19V- \\ ملفص بحث فى :
}

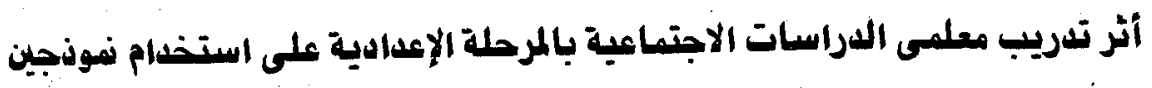

تعليمين فى أنانهم التدريسى وميولهم نصو تدريس الدراسات الاجتماعبة

\author{
دكتور / أحمد جابر أحمد السبد

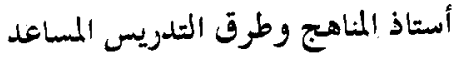

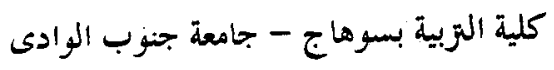

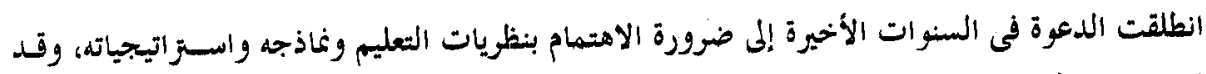

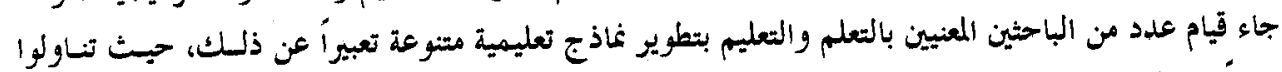

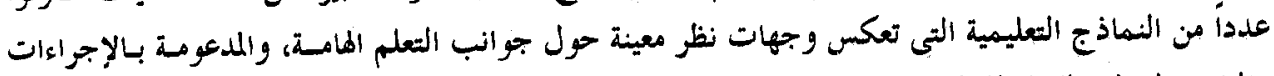

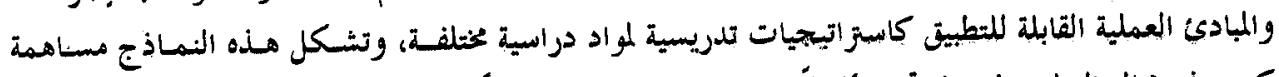

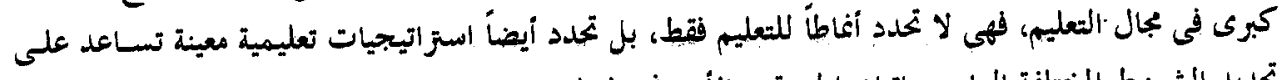

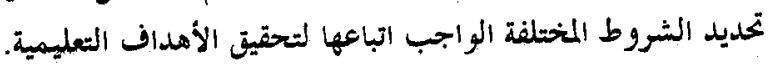

ويغد تموذجا "المنظم المتقدم" و "التعليم المرمى" من النمساذج التعليميسة التى حساولت البمـع بين توضيسح

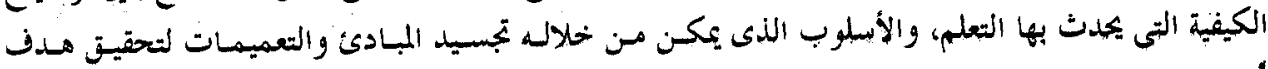

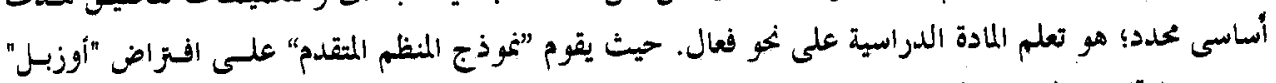

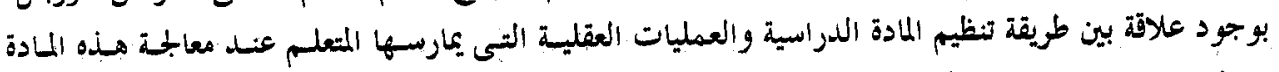

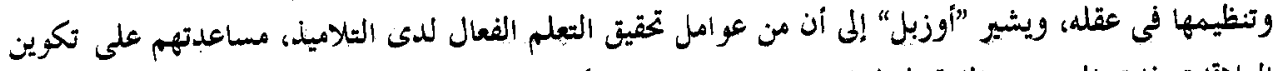

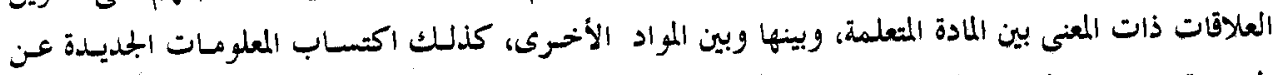

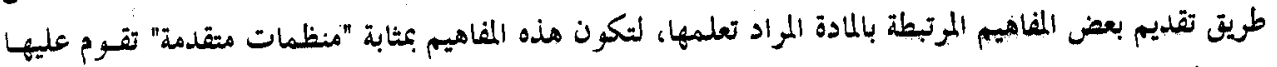

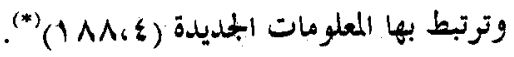

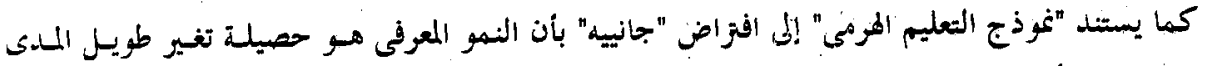

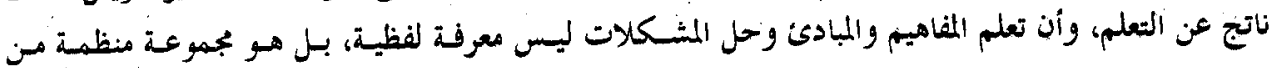

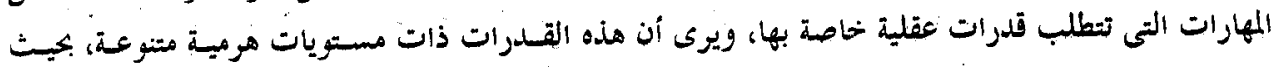

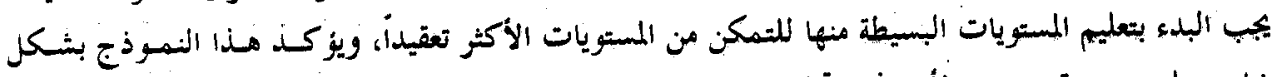

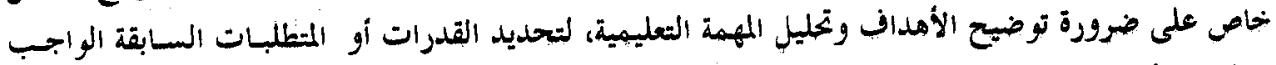

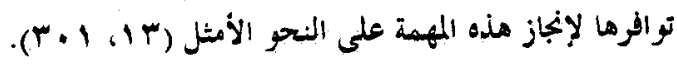

(*) بشيز الرقم الأول إلل رتم المرجع، ويشير الرتم الثانى إل رقم العنحة. . 


\section{$-191-$}

وقد أحبح مذان النموذجان من الإسزاتيجيات التعليمية المستخدمة على نطاق واسع فى عمليتى التعليم

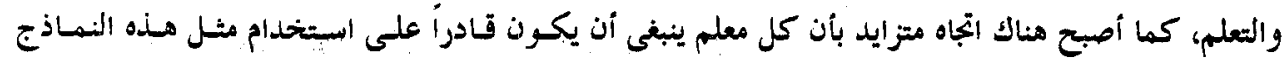

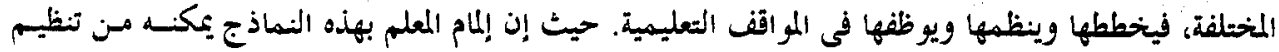

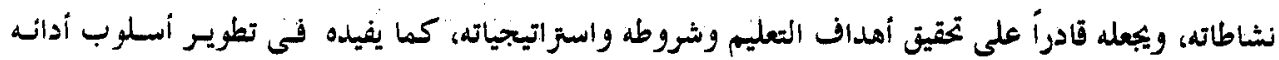

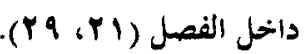

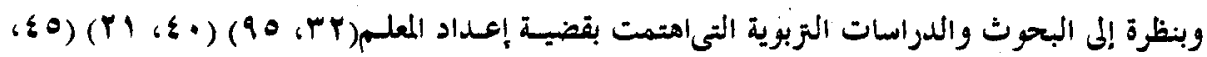

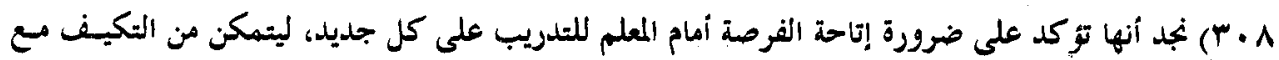

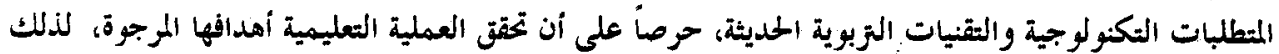

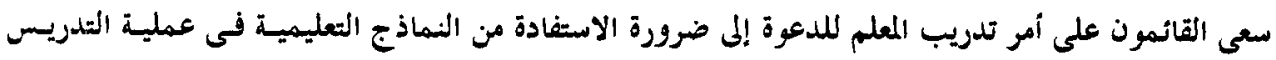

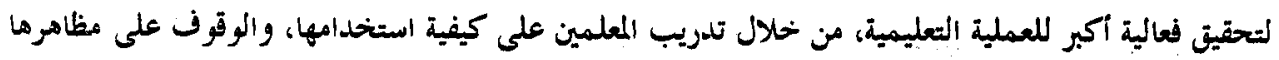

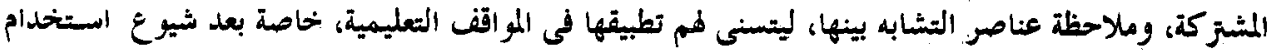
بعض هذه النماذج فى أوضاع تعليمية بحتلفة.

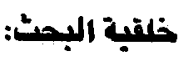

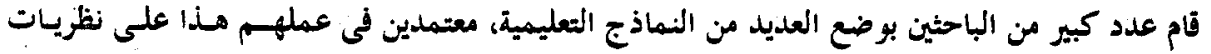

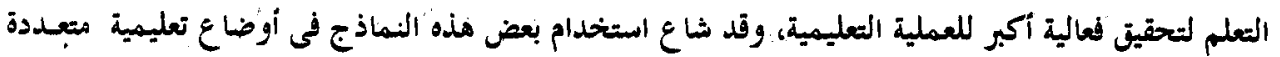

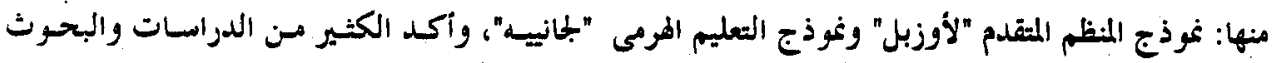
جدواها وفعاليتها فى إنجاز أهداف تعليمية متوعة.

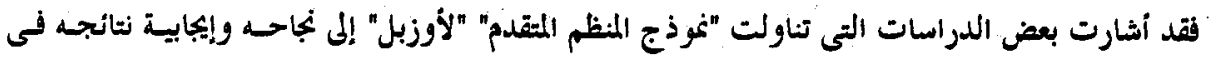

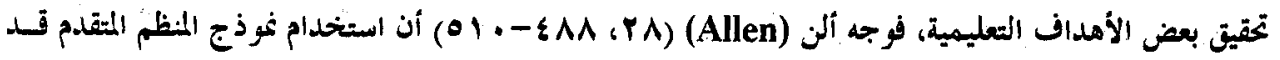

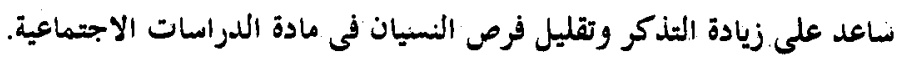

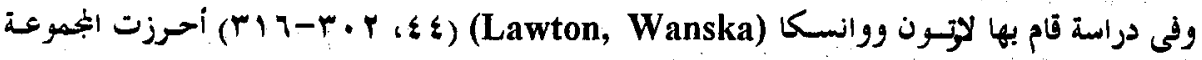
التى درست باستخدام غوذج المظم المقدم تفوقاً دالاً على لجموعة الطريقة العادية فى التحصيل والميول.

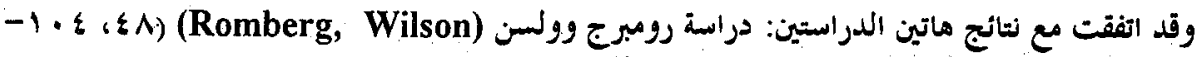

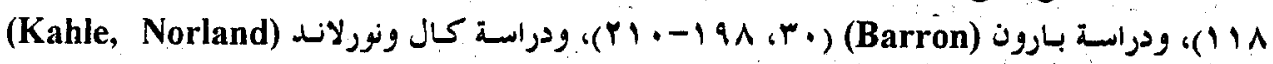

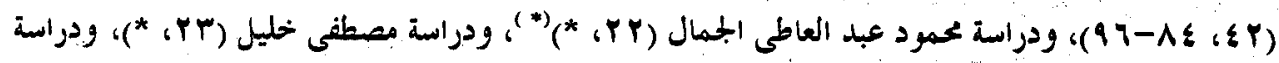

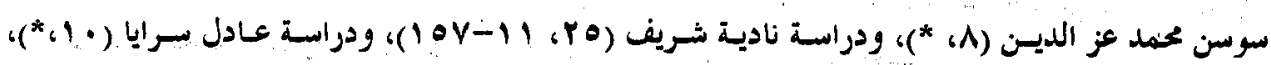

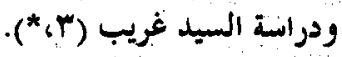


$-199-$

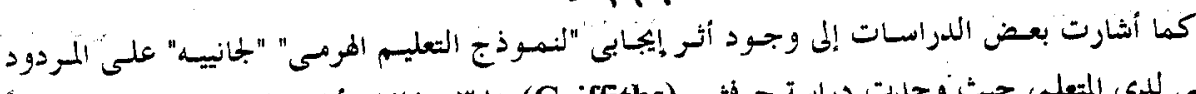

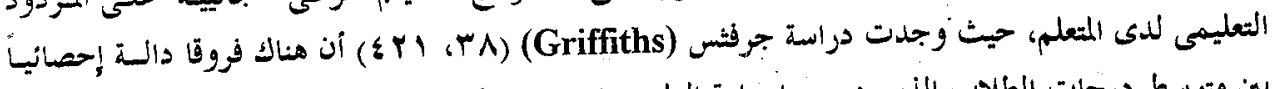

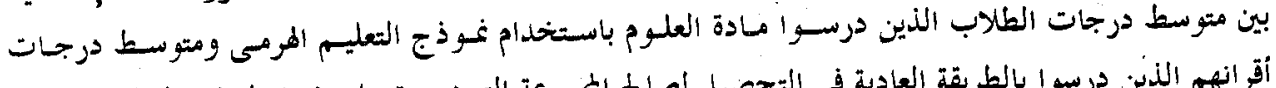

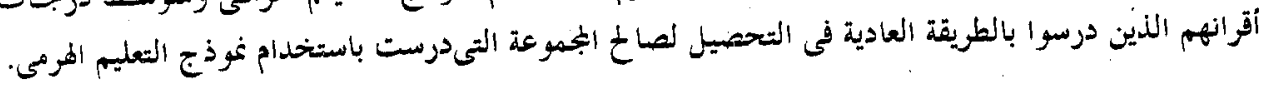

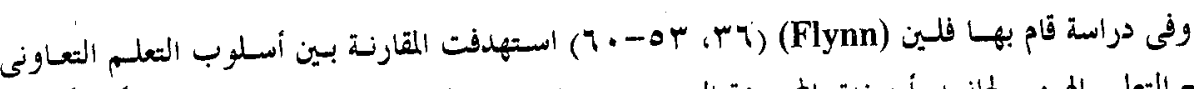

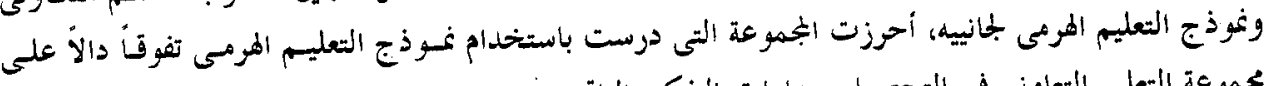

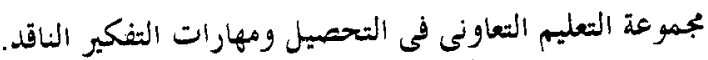

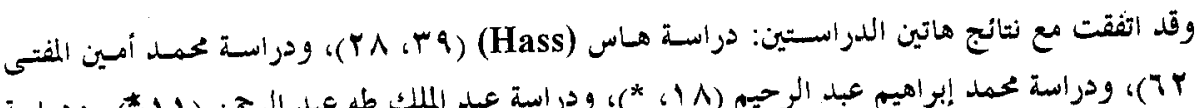

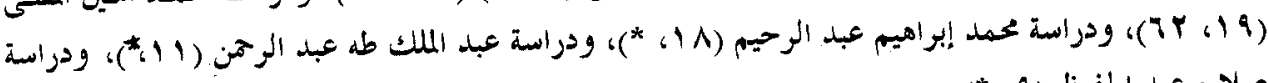

صلاح عبد الحفيظ (9، *).

وفى مقابل الدراسات والبحوث التى تناولت فعالية النماذج التعليمية فى تحقيق بعض الأهداف التعليمية،

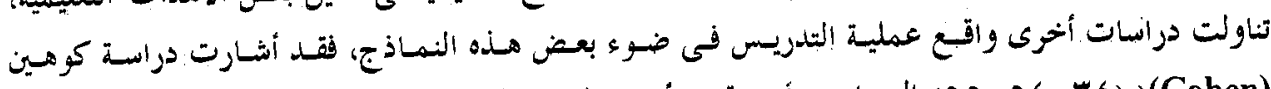

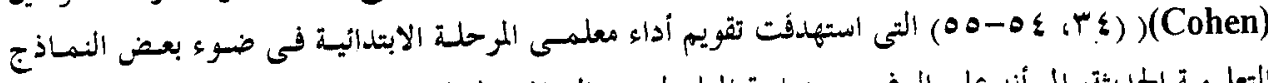

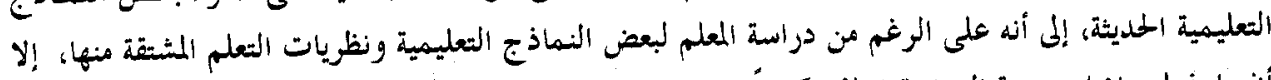

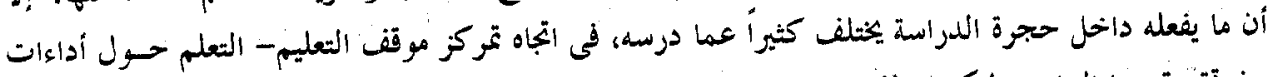

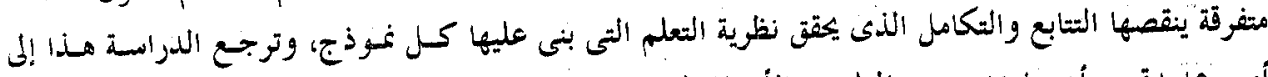

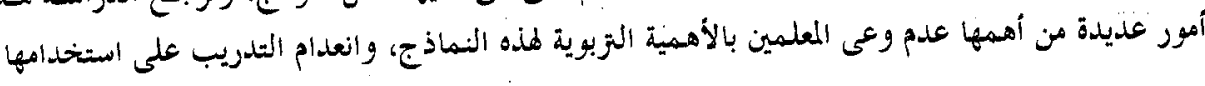

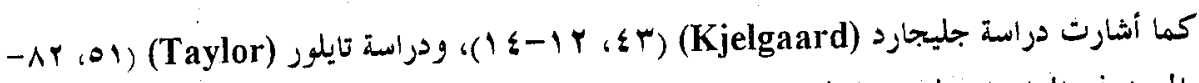

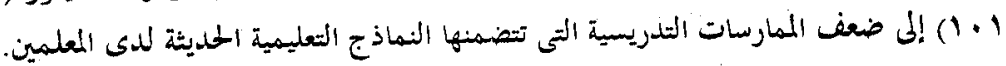

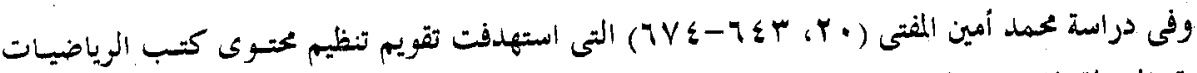

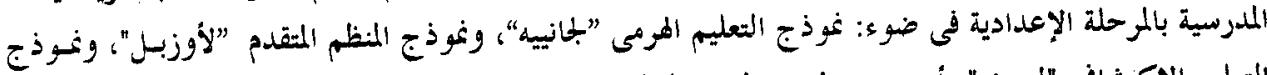

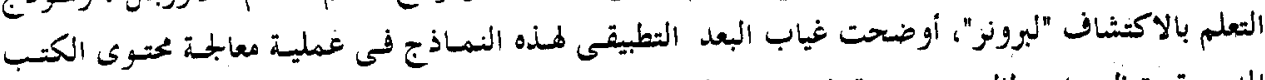

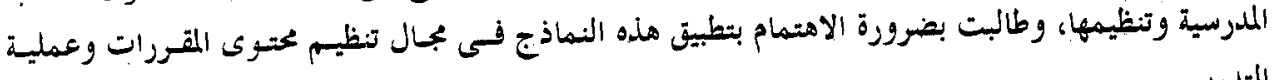
الثدريس.

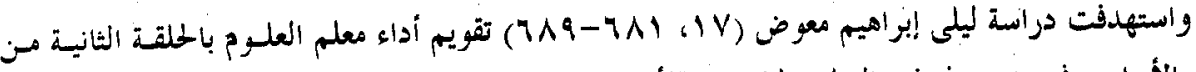

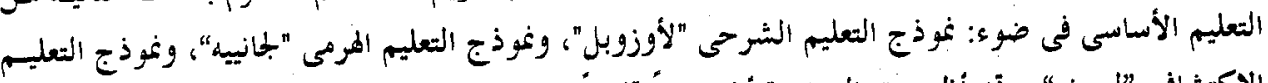

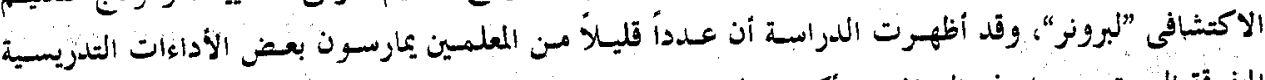

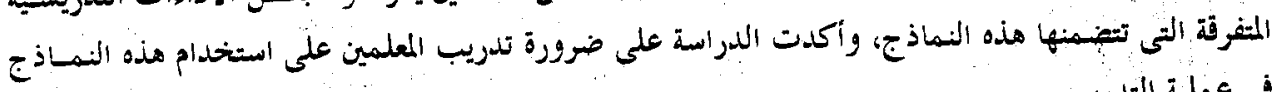
فى عملية الثدريس. 


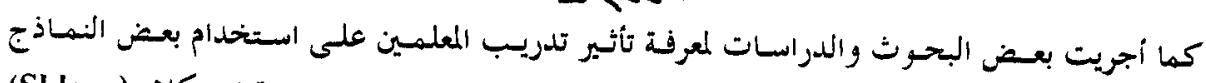

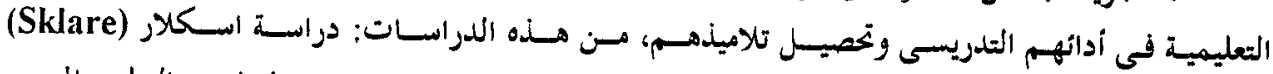

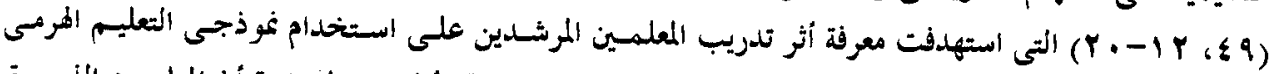

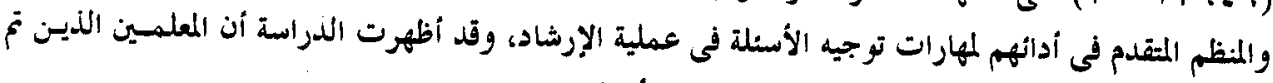
تدريهم قد ارتفعت نسبة استخدامهم المهارات توجيه الأسئلة.

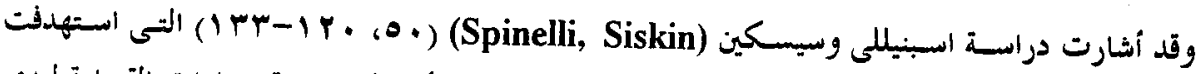

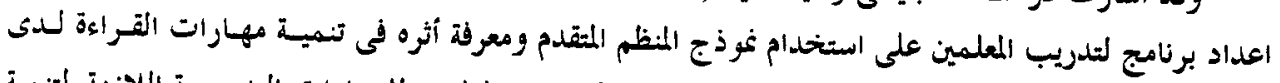

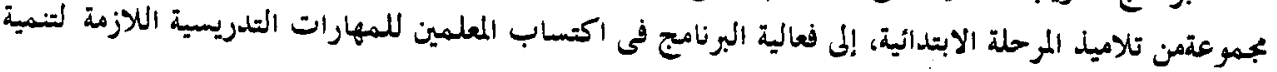
مهارات القراءة، كما ساعد ذللك على ارتفاع مستوى التلاميذ فى هذه المهارات.

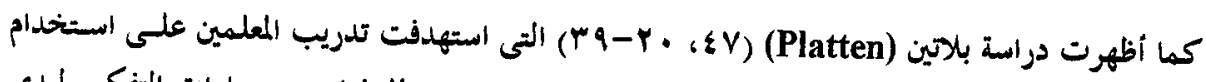

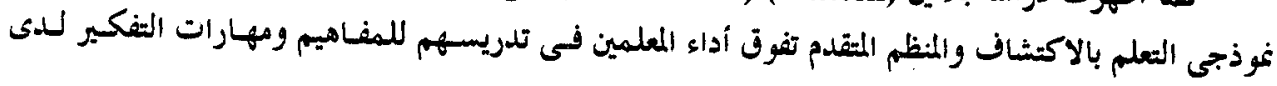
بجموعة من تلاميذ المرحلة الابتدائية.

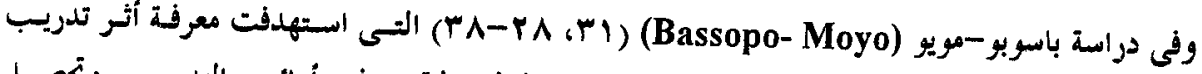

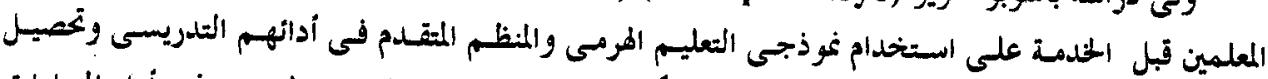

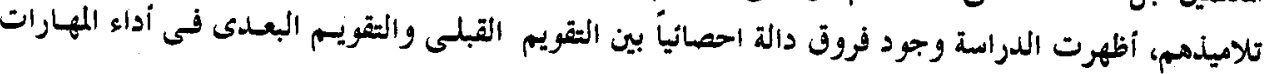
التدريسية لدى المعلمين وارتفاع مستوى تحصيل تلاميذهم.

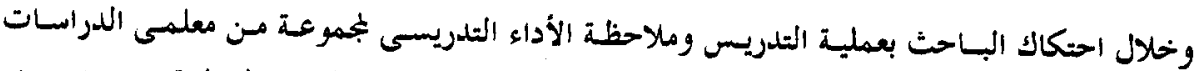

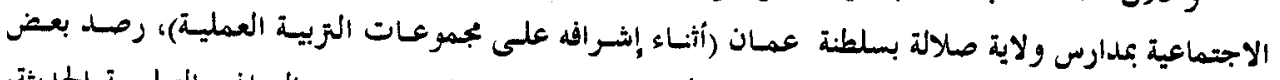

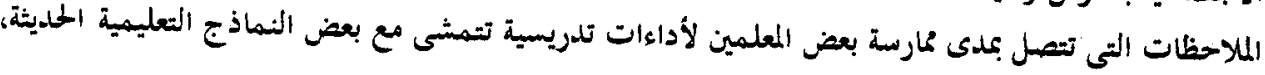

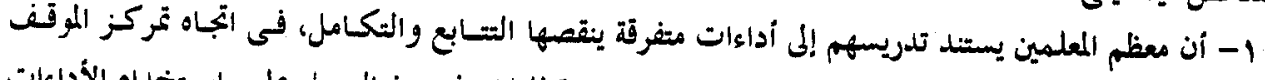

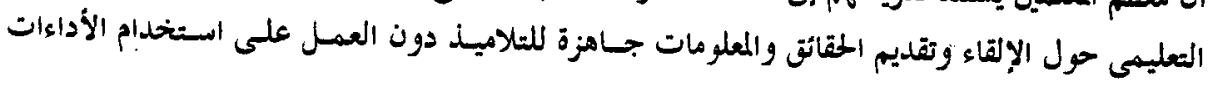

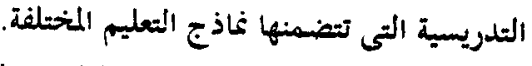

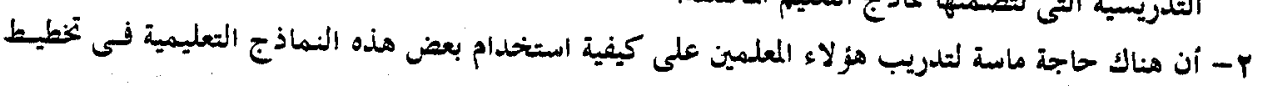
وبناء وتدريس المتوى الدراسى.

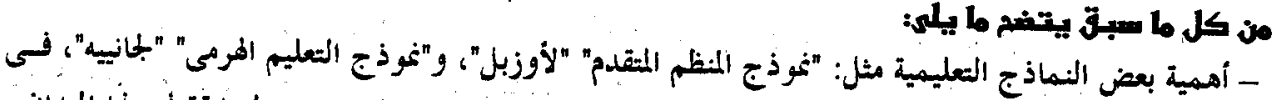

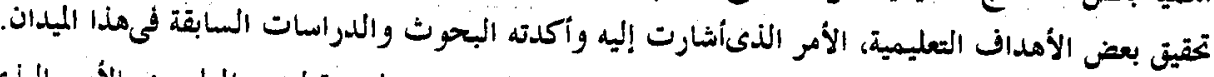

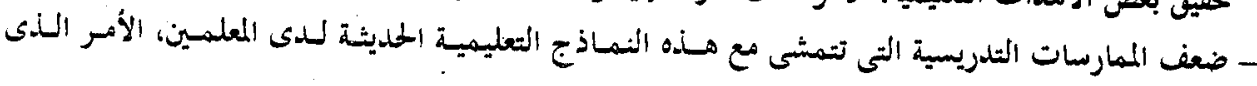
أشارت إليه اللدراسات والبحوث السابقة وملاحظات الباحث. 


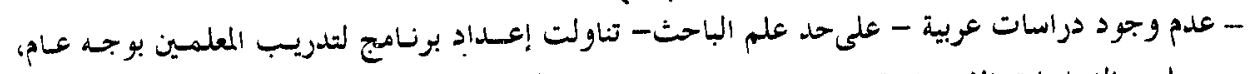

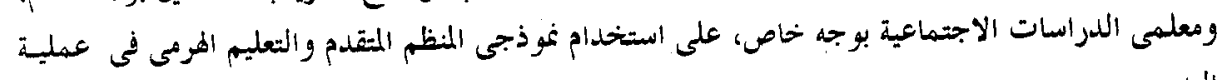

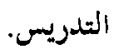

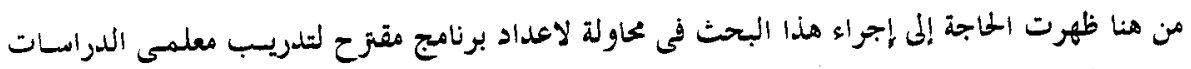

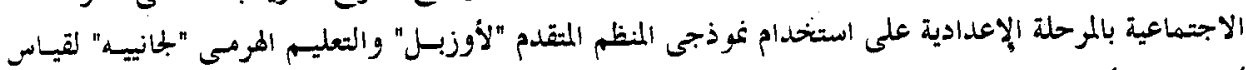

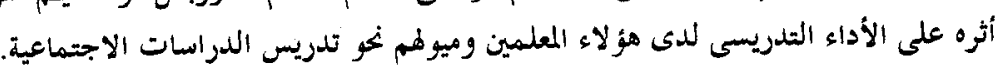

مشكلة البحث:

$$
\text { تحددت مشكلة البحث فى الثوصل إلى إجابة عن التساؤل الرئيس التلأل: }
$$

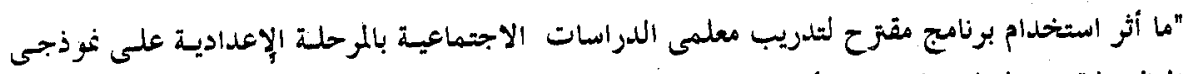

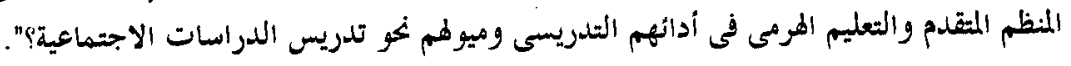

وتتمثل الإجابة عن هذا التساؤل فى الإجابة عن الأسئلة التالية:

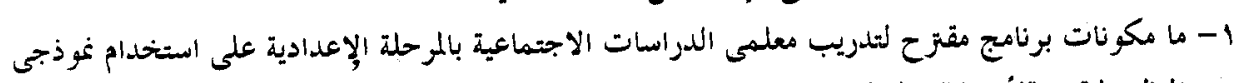

المنظم المتقدم "لأوزبل" و التعليم المومى "لجانييه"؛

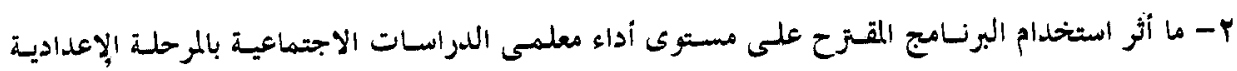

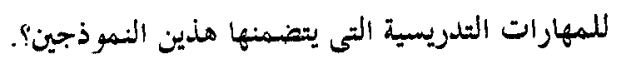

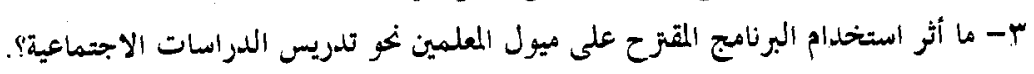

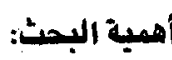 \\ ترجع أهمية مذا البحث إلى أنه:}

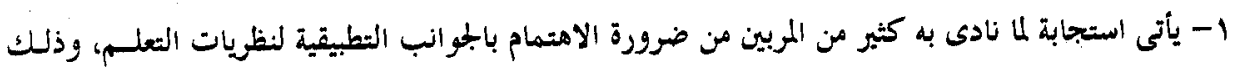

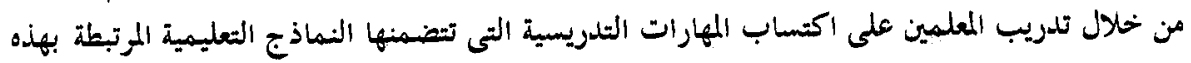

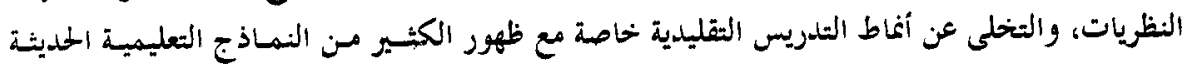

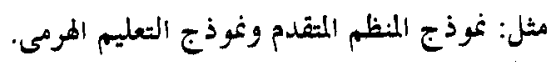

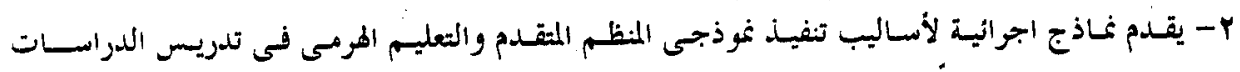

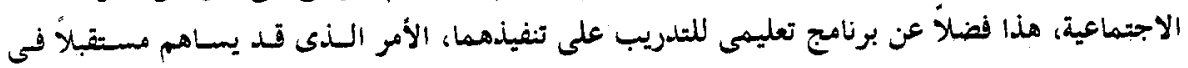

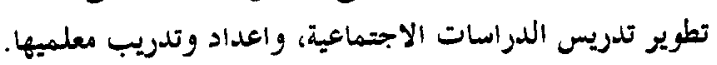

يتم تفسير نتائج هذا البحث في ضوء الحمدود التالية:

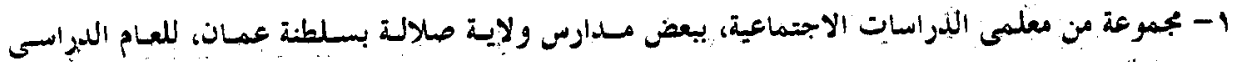
p $447 / 47$

Y - النهوذجان التعليميان اللذأن تم اللدريب عليهـا منا: 
$-5 \cdot 5-$

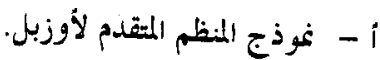

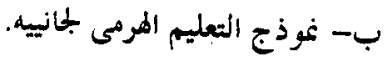

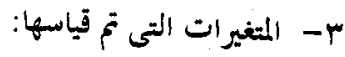

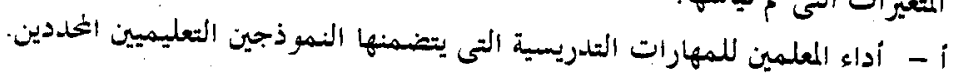

$$
\begin{aligned}
& \text { ب- بـ ميول المعلمين نحو تدريس الدراسات الاجتهاعية. }
\end{aligned}
$$

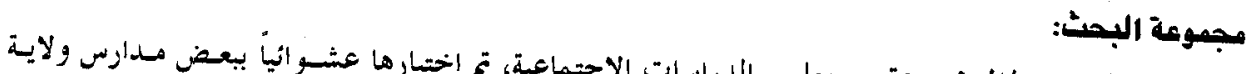

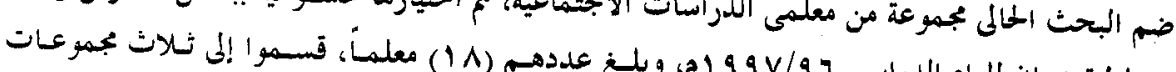

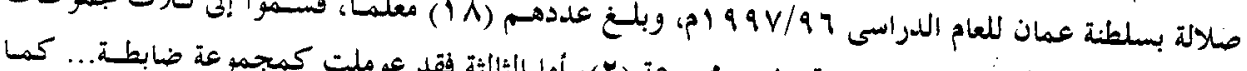

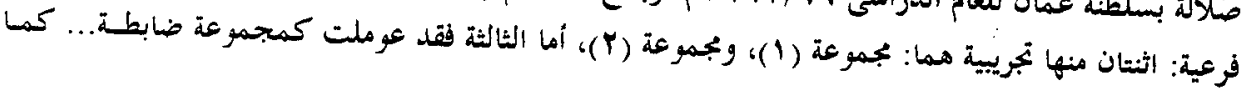

يلى:

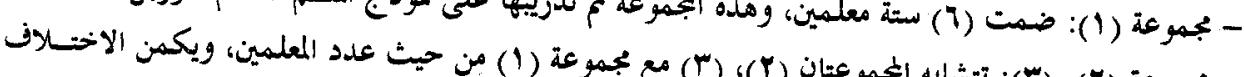

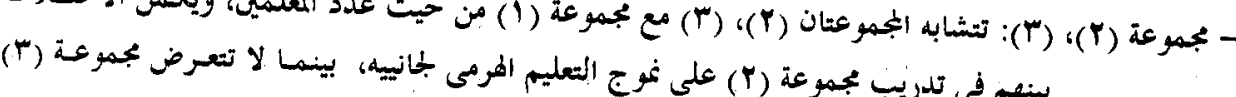

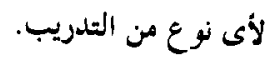

منهج البحث: أدوات البحث:

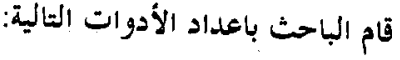

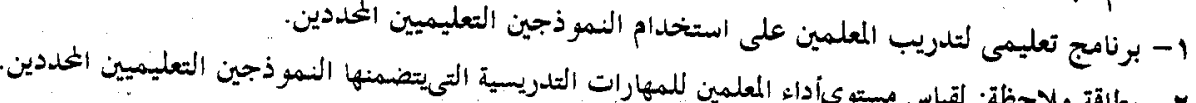
r- ب- مقياس بلميول نحو تلدريس الدراسات الاجتماعية.

حاول البحث الحالي الختبار صحة الفروض التالية:

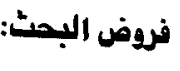

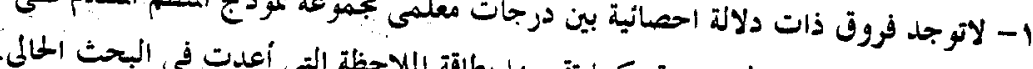

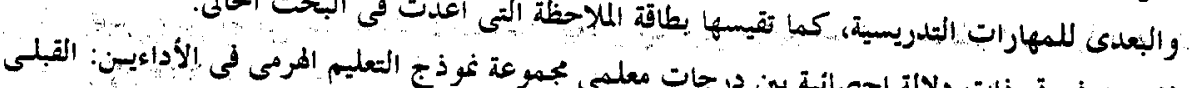

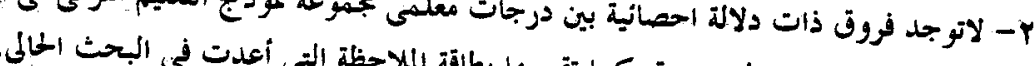

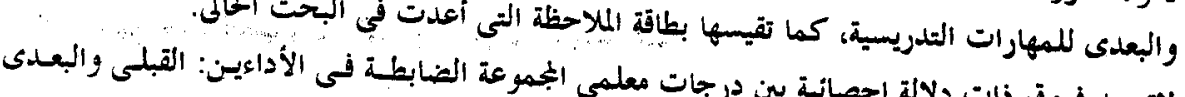

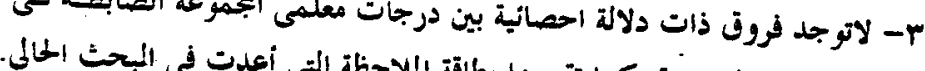




\section{$-2 \cdot r-$}

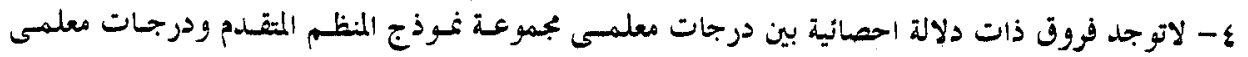

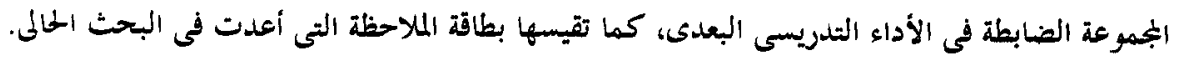

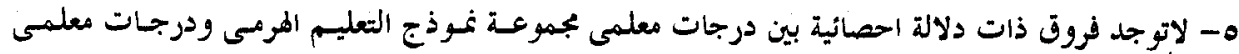

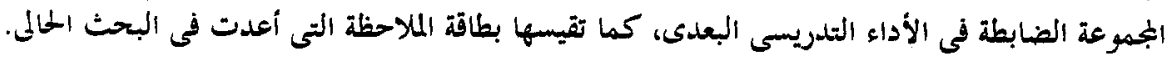

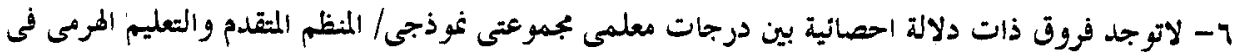

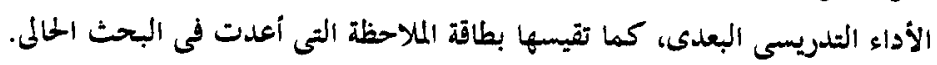

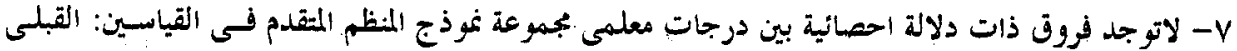

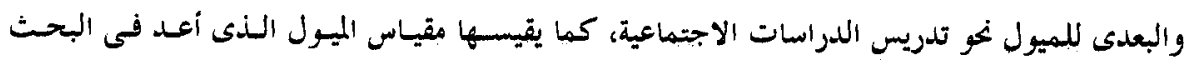

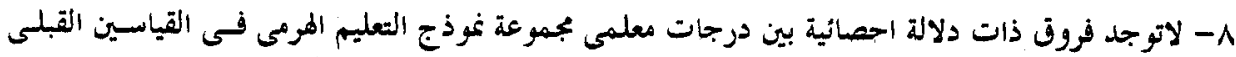

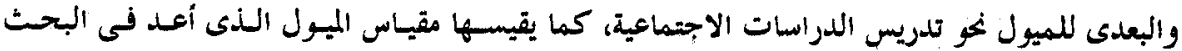

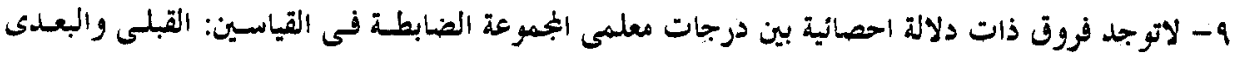

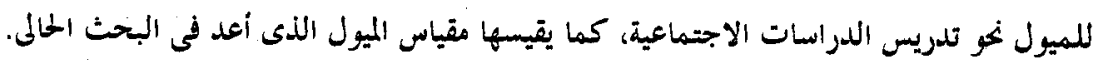

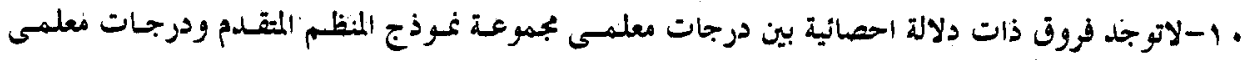

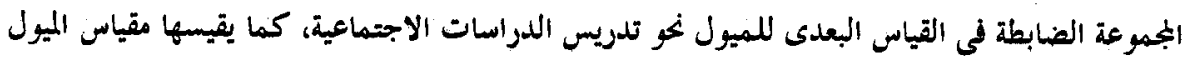

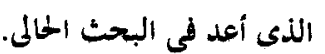
1)

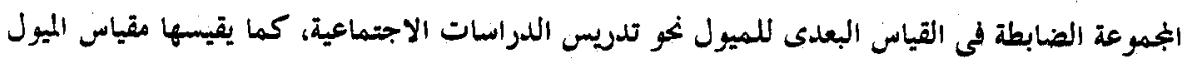

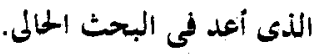

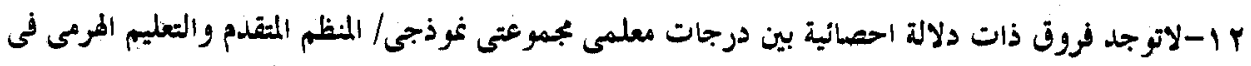

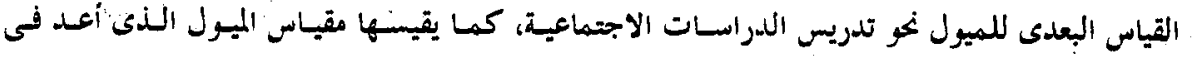
البحث الحلالي. مصطلحات البحث: البح: فيها يلى تعريف للمصطلحات المستخدمة في هذا البحث:

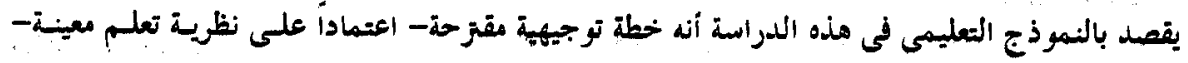

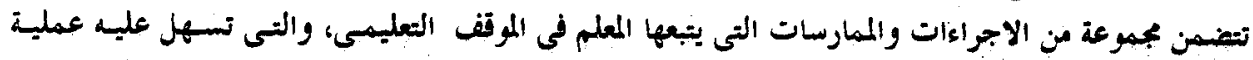
تغطيط نتاطاته وتنفيلمها وتثويمها. semaxallalil-

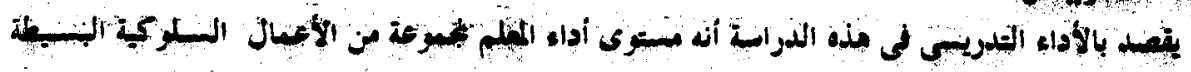

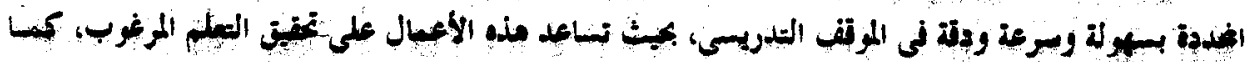

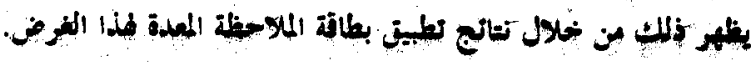




\section{$-5 \cdot \varepsilon-$}

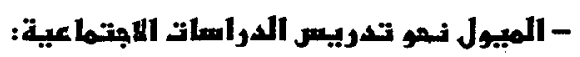

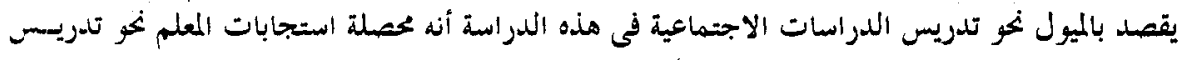

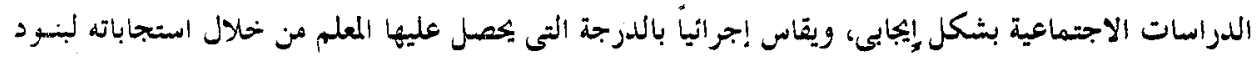

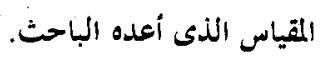

$$
\text { تضشنت خطو ات البحث ما يلى: }
$$

$$
\text { خملوات البحث: }
$$

أوبًا : دراستة نئلرية عنز:

- مفهوم النموذج التعليمى - الأسس القانم عليها كل من نموذج المنظم المتقدم ونوذج التعليم المرمى. ثانياً: دراسة تجهريبية وتشمنت:

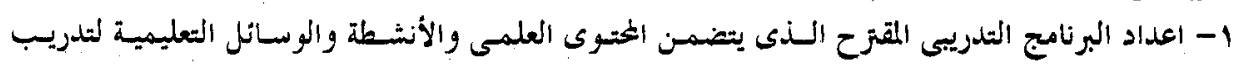
المعلمين على النموذجين التعليميين الغحددين.

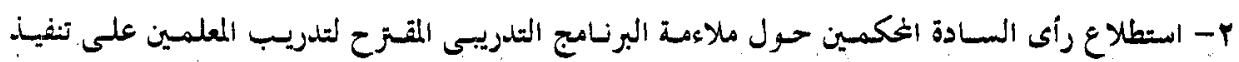

$$
\text { النموذجين التعليمين. }
$$

ب- اعداد بطاقة الملاحظة، وعرضها علي السادة المحكمين للتأكد من صلاحيتها، ثم ضطبها إحصائياً.

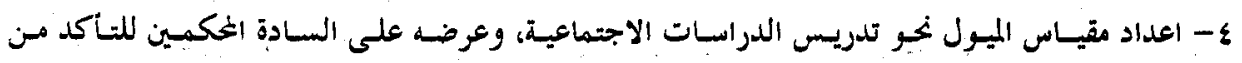
صلاحيته، ثم ضبطه احصائياً.

ه- اختيار مجموعة البحث: من معلمى الدراسات الاجتماعيةبالمرحلة الاعدادية.

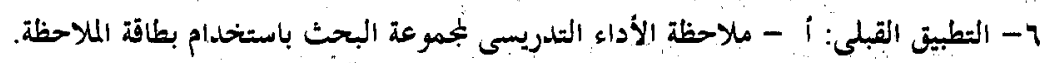

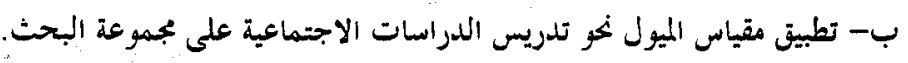

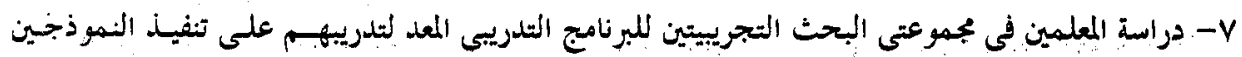

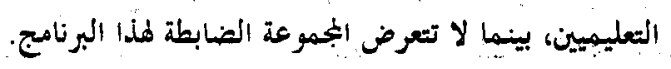

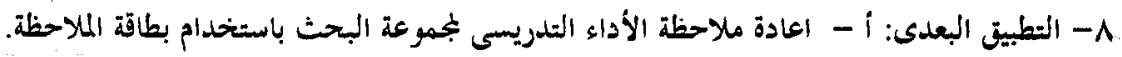

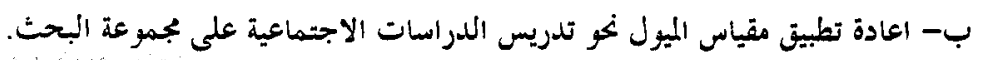

9- معالجة النتائج احصائياً وتحليلها وتفسيرها. • 1- ا- تقديم بعض التوصيات والمقتزحات.

الإطار النظرى:

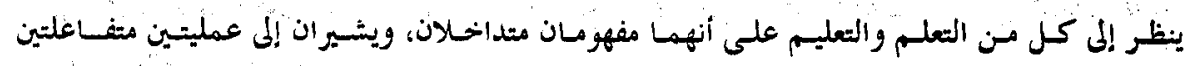

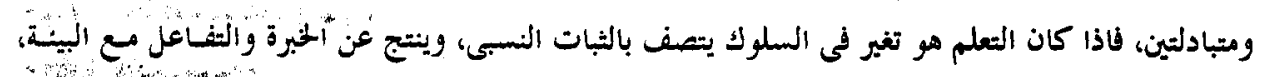

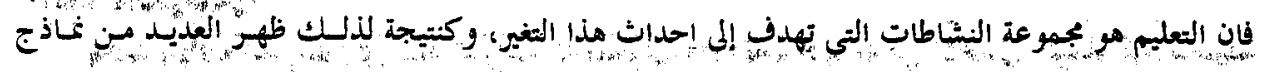

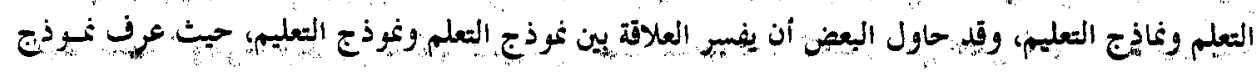

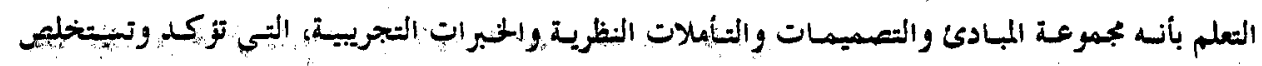


- 5.0-

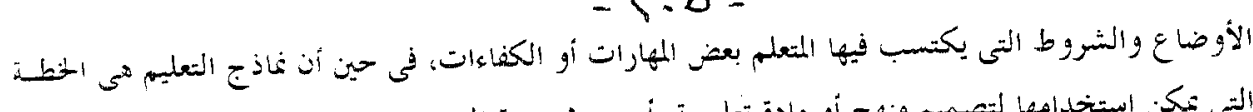

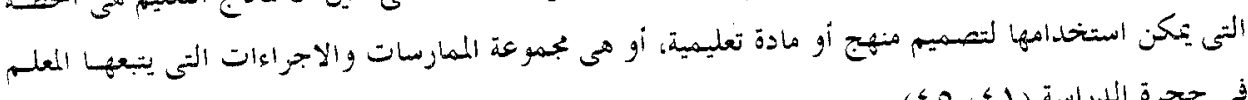
في حجرة الدراسة (1)، 0؛

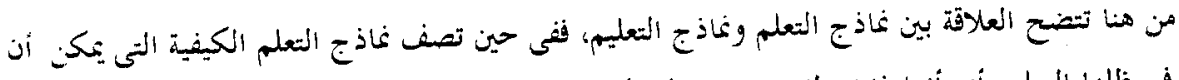

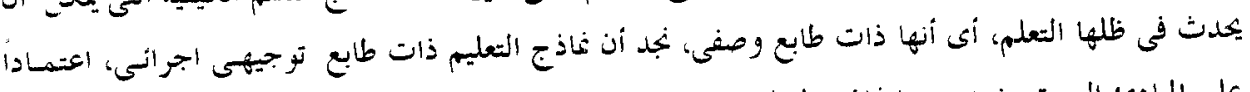

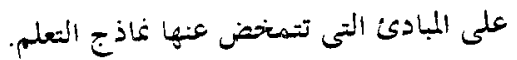

وقد طور علماء النفس المهتمون بالتعلم والتعليم نماذجاً تعليمية متنوعة تعكس وجهات نظر معينسة، حسول

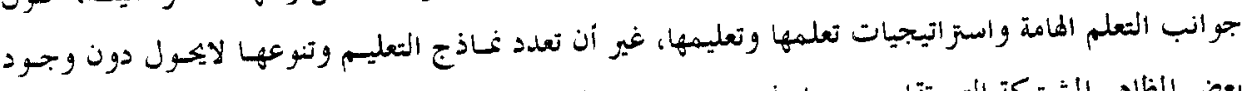

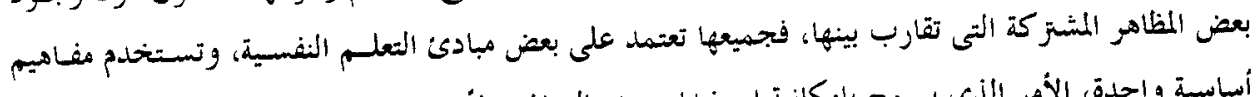

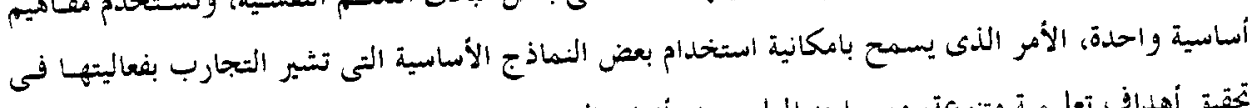

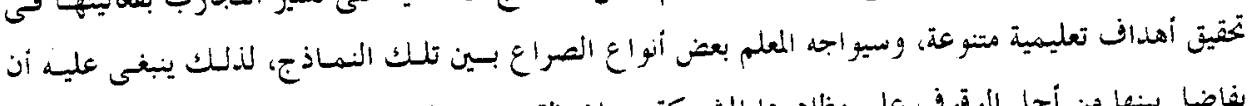

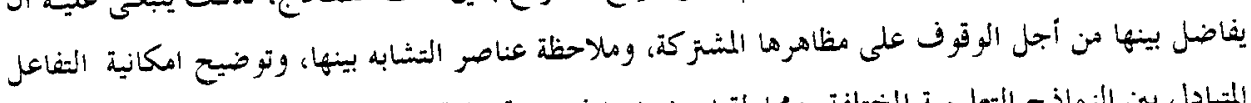

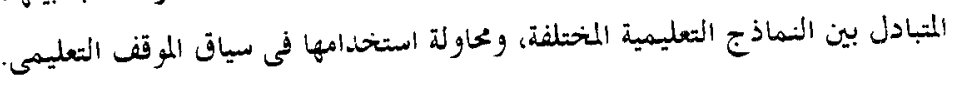

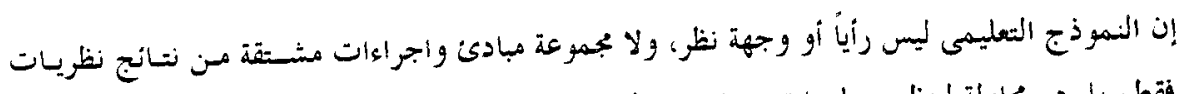

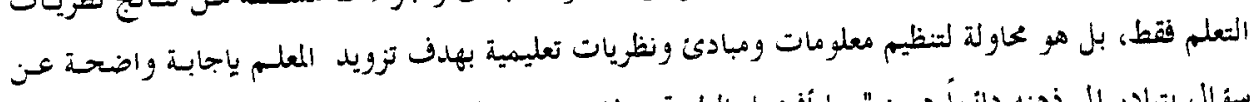

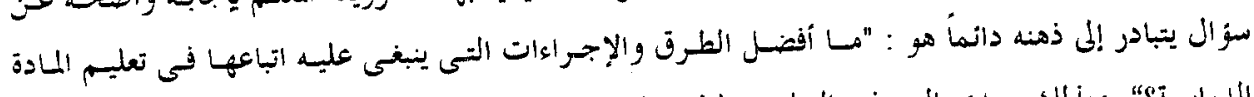

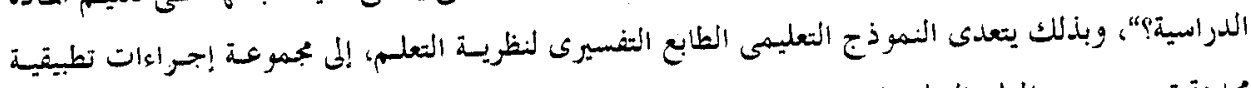

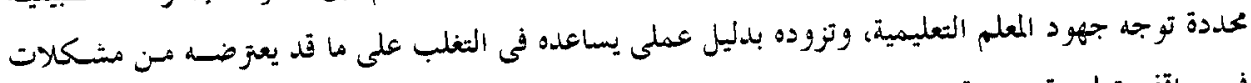
فى مو اقف تعليمية متنوعة.

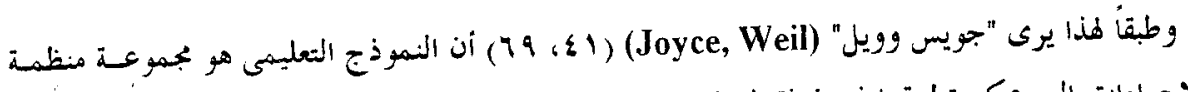

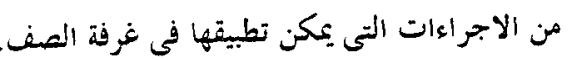

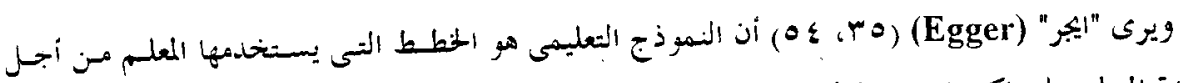
مساعدة المتعلم على اكتساب خبرة في موضوع معين.

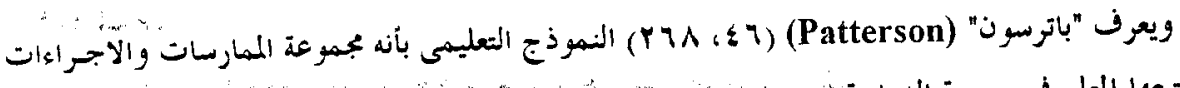
التى يتبعها المعلم فى حجرة الدراسة. 
$-5 \cdot 7-$

وعلى ذلك يتسم النموذج التعليمى بمجموعة من الخصائص تتلخصض فيما يلى:

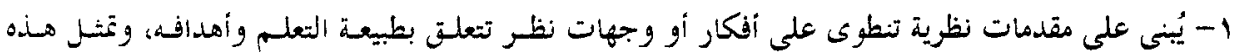

المقدمات خطة توجيهية مقزحة للنموذج التعليسى.

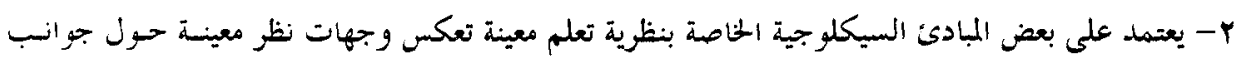

$$
\text { التعلم الهامة واستز اتيجيات تعلمها وتعليمها. }
$$

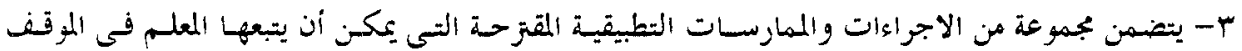

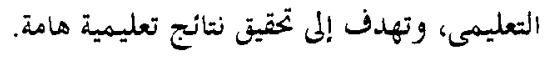

ويقصد الباحث بالنموذج التعليمى فى هذه الدراسة أنه خطة توجيهية مقترحة- اعتهادا على نظرية تعلـم

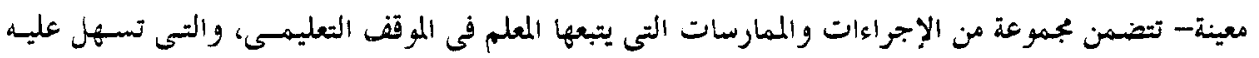
عملية تخطيط نشاطاته وتنفيذها وتقويمها. معايير النموذج التعليمى البيد:

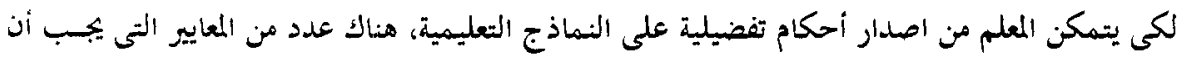

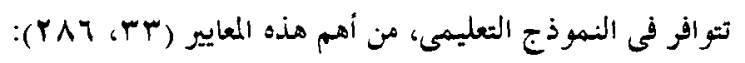

أ - الألمبية:

يجب أن ينطوى النموذج التعليمى على أهمية خاصة تستثير اهتمام المربين والمعلمين، وتدفعهم إلى تطبيقه،

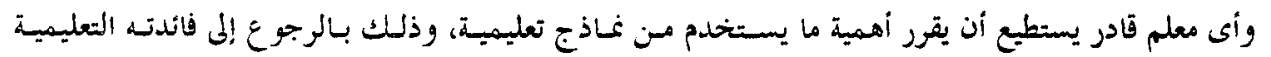

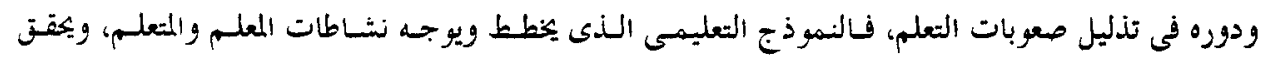

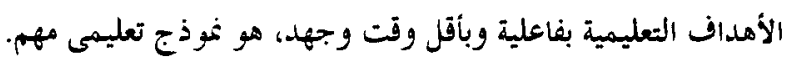
ب- النقة والوضوح: ينبغى أن يكون النهوذج التعليمى مفهومأ، خاليًا من الغموض، ذا اتساق دالخلى منطقى، وتتحقتى هـذه

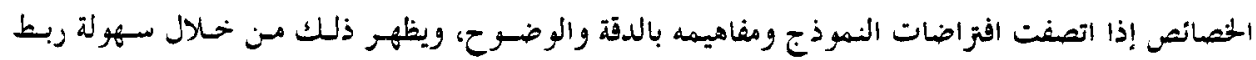
مفاهيم النهوذج بالإجراءات التطيقية، وفى القدرة على تحديد استز اتيجيات الثلدريس الممكنة.

يكون النهوذج التعليمى جيداً إذا كان قادرأ على معالجة أكبر عدد ممكن من متغيرات العهليـة التعليهية،

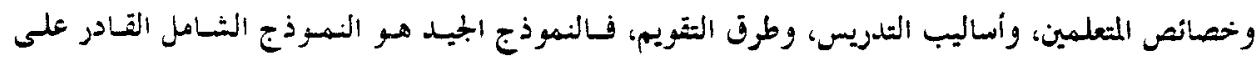
تزويد المعلم بتوجيهات تمكنه من تحديد الاجراءات الواجب اتباعها تجاه مذه المتغورات جميعها.

\section{- م- الإهرائية:}

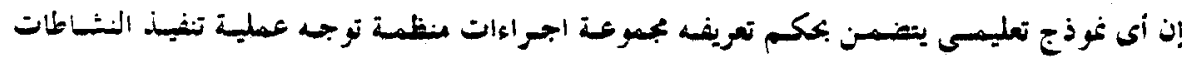

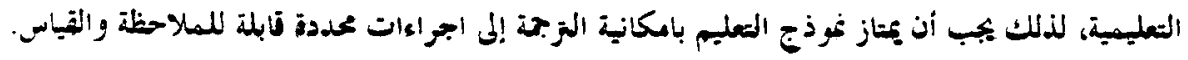




\section{أنواع من النعادج التعليمبة:}

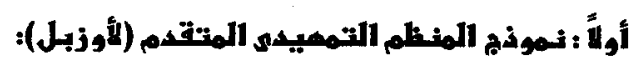

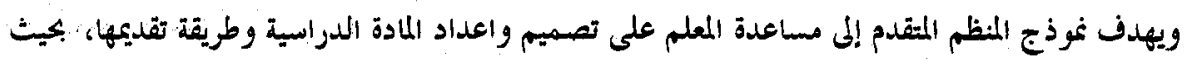

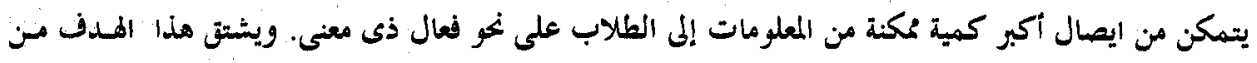

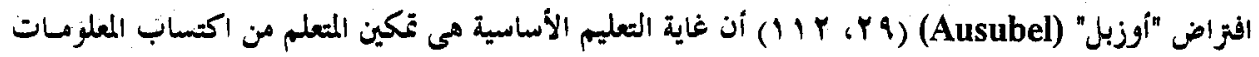
والاحتفاظ بها ونقلها إلى أوضاع جديدة.

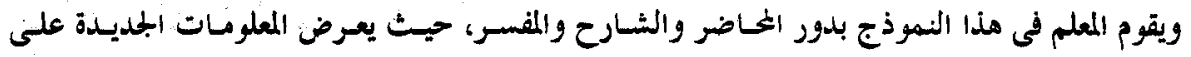

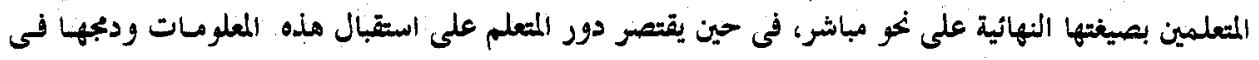

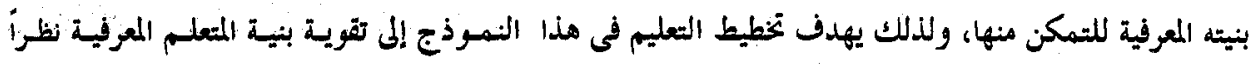

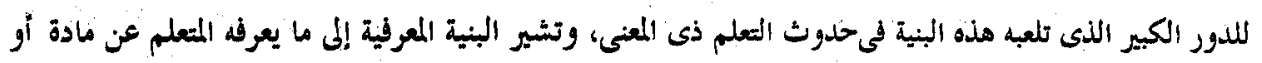

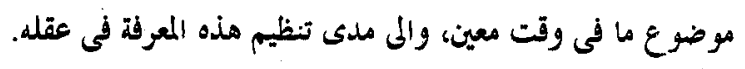

ويشير "أوزبل" إلى أن بنية المتعلم المعرفية تشكل عاملاً رئيسياً فى تعليم المادة التعليميسة الجيسدة، وتسهيل

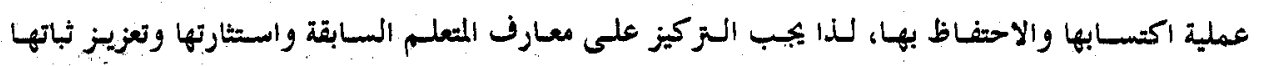

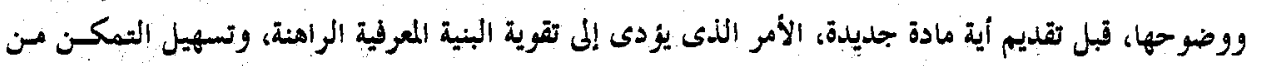

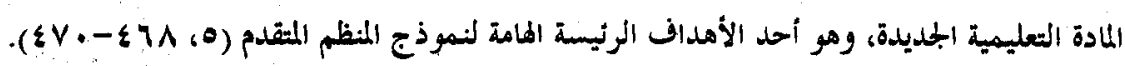

ويوضح "أوزبل" أن تعليم المادة الدراسية لايتوقف فقط على أسلوب تقديثها، بل على طيعة البنية المعرفية

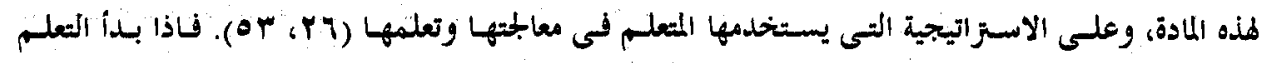

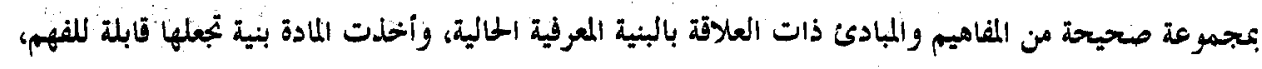

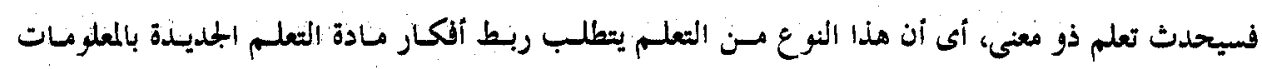
المعروفة سابقاً لتشكيل أفكار جديدة.

- مغموم المنظمات المتقدهة:

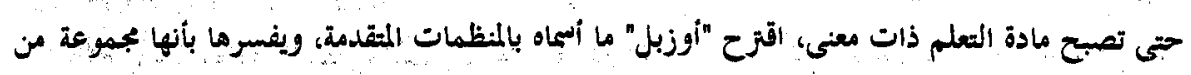

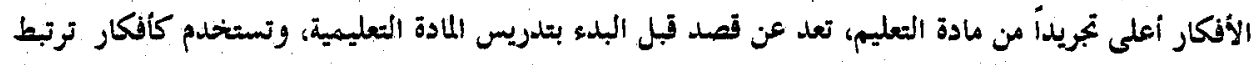
بمادة التعلم الجلديدة.

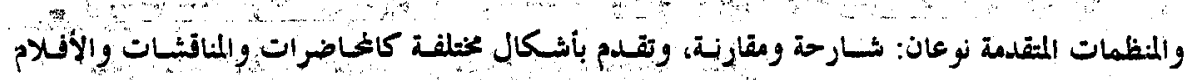

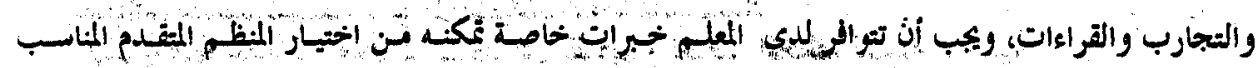
وتخطيطه وتقديه بالشكل المناسب. 


$$
\begin{aligned}
& -\Gamma \cdot \lambda-
\end{aligned}
$$

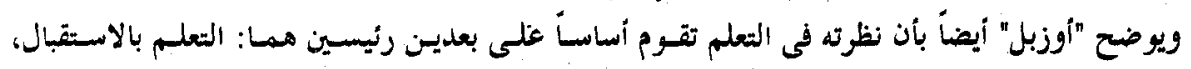

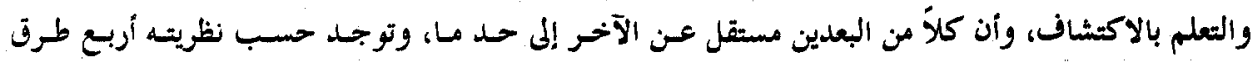

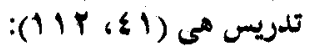

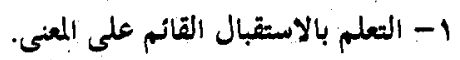

$$
\begin{aligned}
& \text { r- ب التعلم بالاستقبال القائم على الحفظ. } \\
& \text { r- التعلم بالاكتشاف القاتم على المعنى. } \\
& \text { ؛- التعلم بالاكثشاف القايم على الحفظ. }
\end{aligned}
$$

- شطوات المنظم التمهيدي المتقعدم:

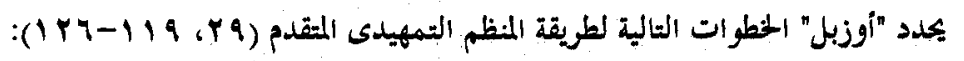

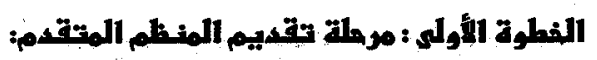

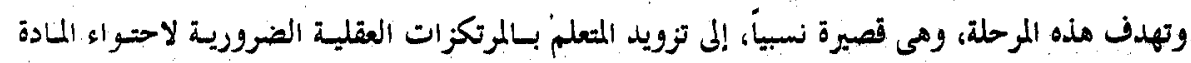

ألدراسية، وديجها في بنيته المعرفية، وتتضمن الأنشطة التالية:

أ - توضيح أهداف الدرس:

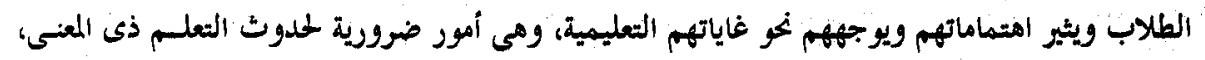

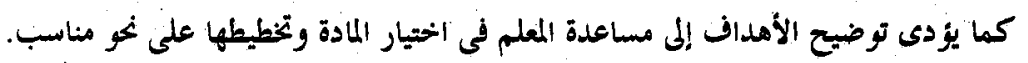

ب- بـ تقديم المنظم المقددم:

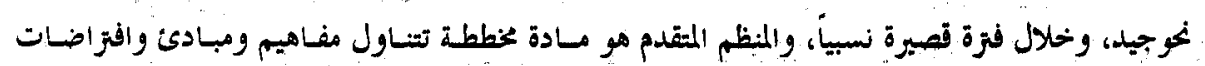

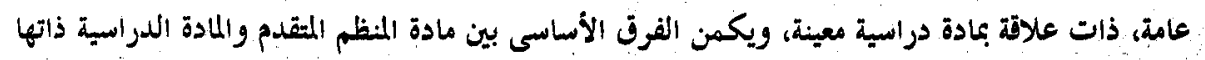

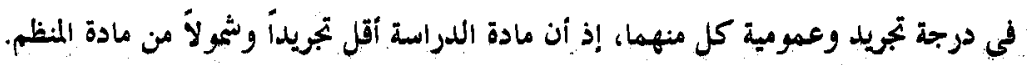

ج- استثارة وعي المتعلم بالمعرفة ذات العلاقة:

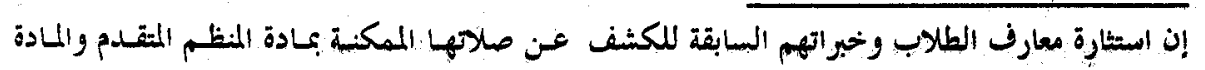

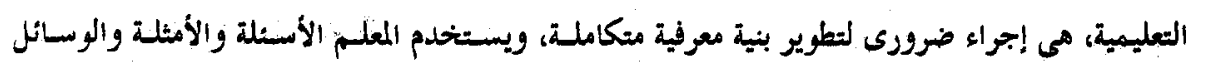

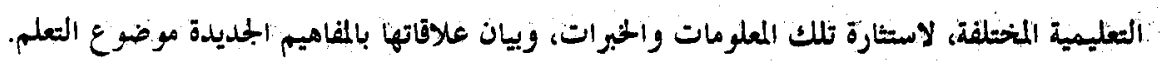

النطوة الثانية : مورولة تقديم المادة الدراسية:

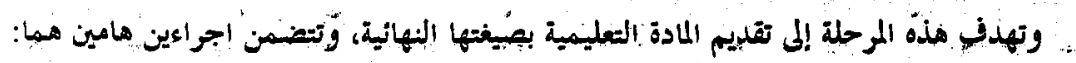

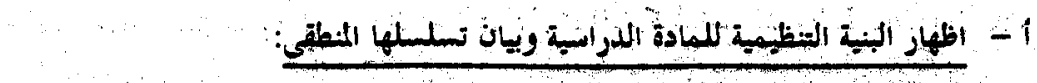

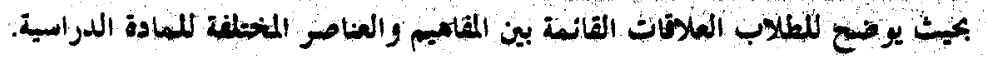




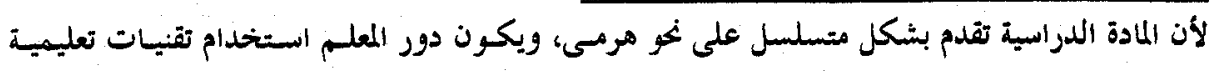

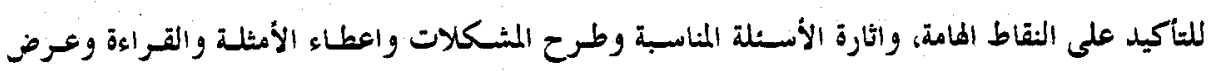

$$
\text { الوسائل التوضيحية. }
$$

\section{الفطوة الثالثة : مرملة ثقويةالتنظليم المعرخى:}

وتهدف مذه المرحلة إلى تثيت المادة الدراسية الجلديدة فى بنية المتعلم المعرفية، وتتضمن الإجراءات المعات التالية:

$$
\begin{aligned}
& \text { أ - - استخدام مبادئ دمج المادة الجديدة فى البنية المعرفية للمتعلم. } \\
& \text { ب- الحت على التعلم الاستقبلا النشط. } \\
& \text { جـ- استثارة التفكير النقدى أو التقويمى عند الطلاب. } \\
& \text { د - توضيح المفاهيم والأفكار غير الواضحة. }
\end{aligned}
$$

ومن الأساليب التى يمكن أن يستخدمها المعلم من أجسل مسـاعدة التلاميلد على دمج خبر اتهم الجلديدة.

$$
\text { بأبنيتهم المعرفية ما يلى: تلئي }
$$

- تذكير الللاميذ بالصور المعرفية الكاملة (الأهداف العافئل العامة).

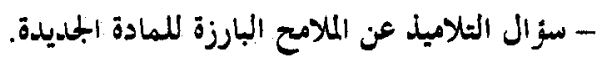

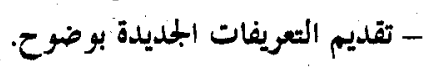

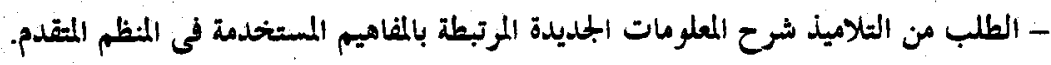

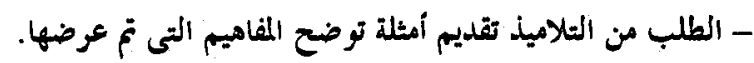

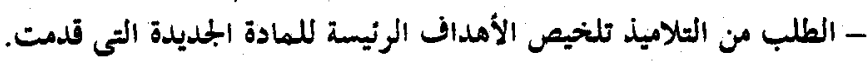

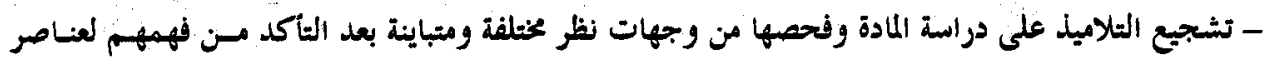

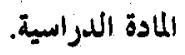

- الطلب من الملاميد ربط المادة الجلديدة بالحبرات الثخصية لديهم.

- معيزات نموذج الهنظم التهميدمى المتقدم:

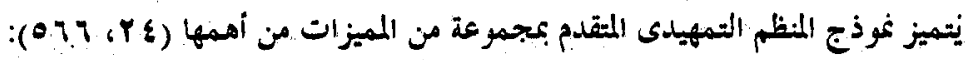

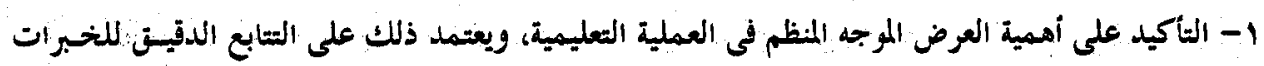

التعليية بحيث ترتبط ارتباطأ واضحأ بما يسبقها.

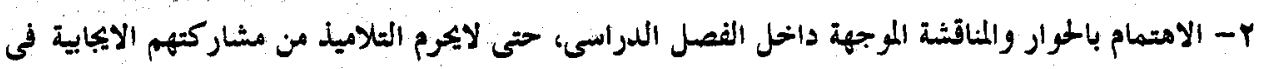

$$
\text { المواتف التعليمية. }
$$

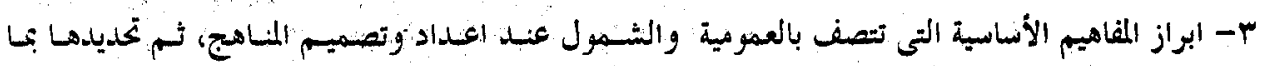

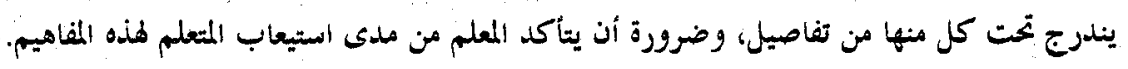


؛ - الاهتمام بعنصرى التنظيم والمعنى فى كل ما يعرضه المعلم على المتعلمين.

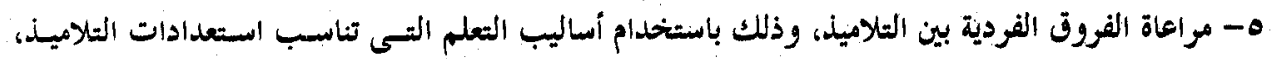

$$
\text { حتى يمكن تحقيق أعلى درجة من الكفاية فى مواقف التعلم. }
$$

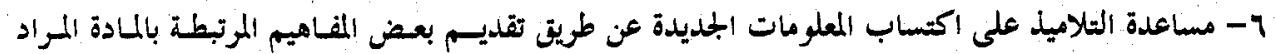

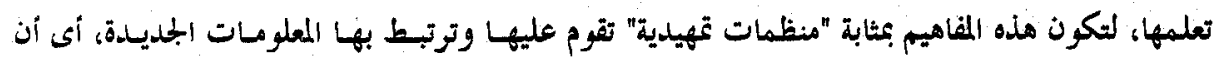

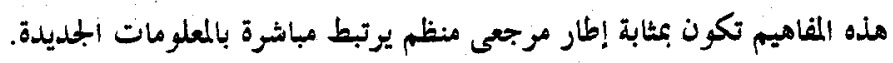

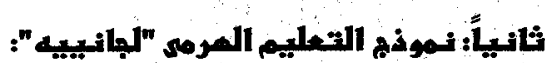

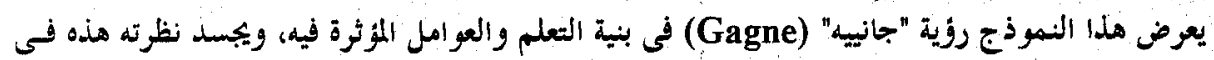

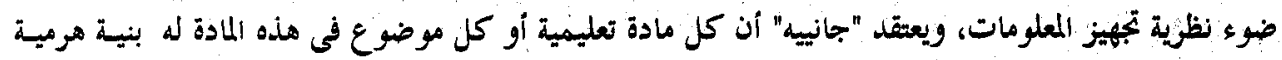

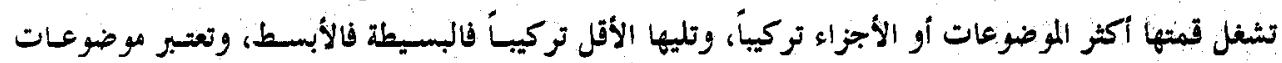

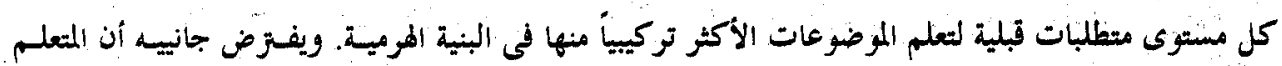

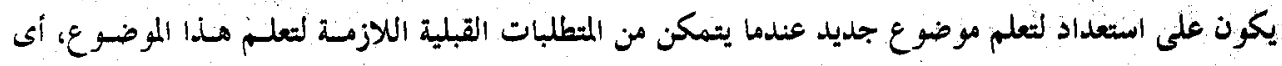

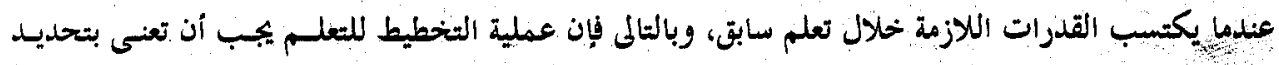

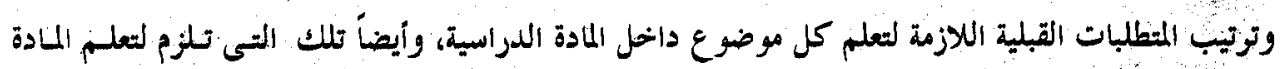

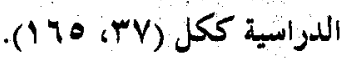

ويرى "جانييه" أن الطبيعة المرمية للقدرات العقليـة تعهل كأسـاس لتطويبر اسـز اتيجيات تعليهية فعالة،

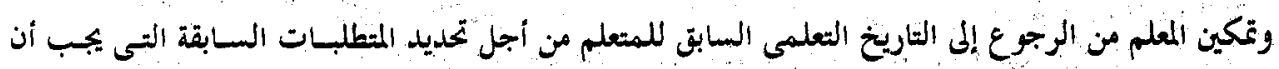

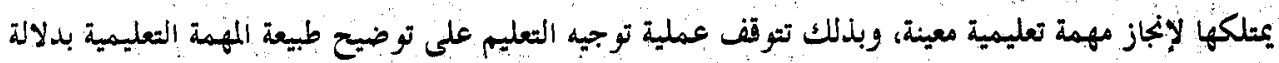

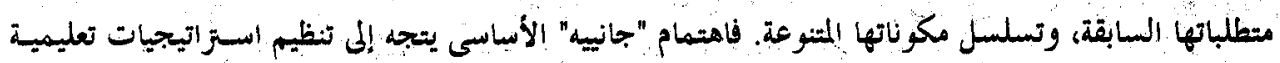

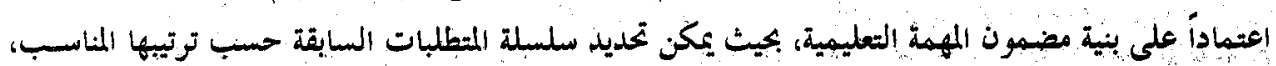

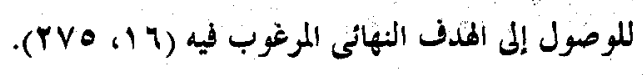

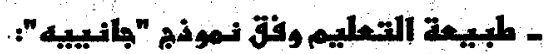

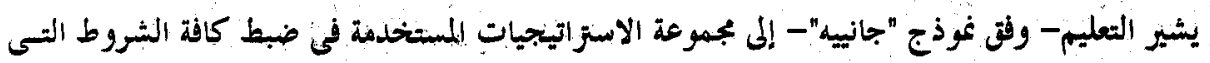

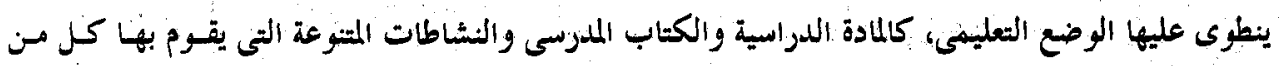

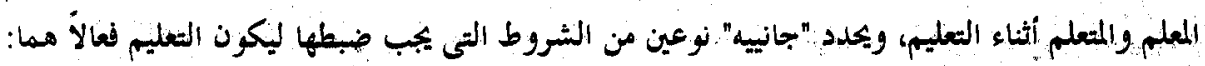

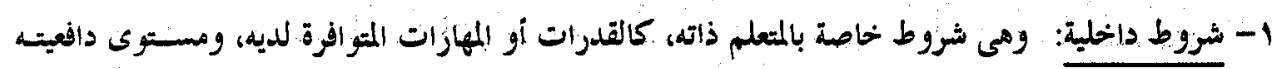

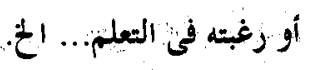

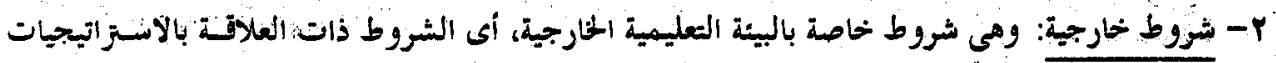

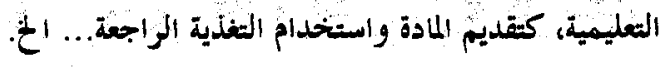


$-511-$

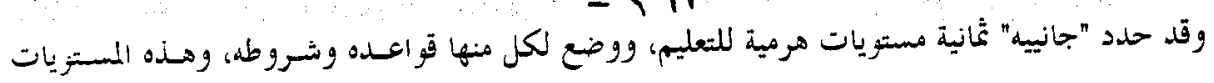

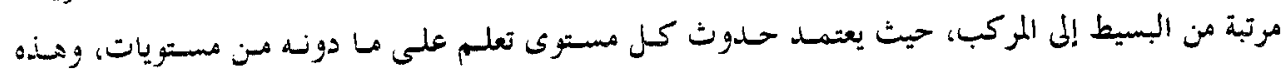

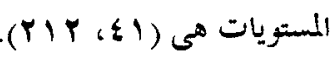

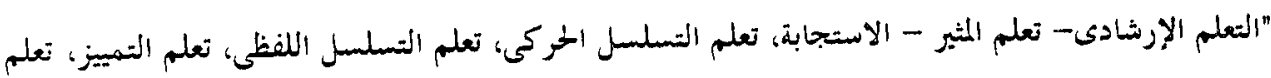
المفهوم، تعلم القاعدة، تعلم حل المثكلة".

ويعتقد "جانييه" أن هذه المستويات تشكل نسقاُ هرمياً متصاعداً، أى أن كل صنف من التعلم يعد متطلبـا

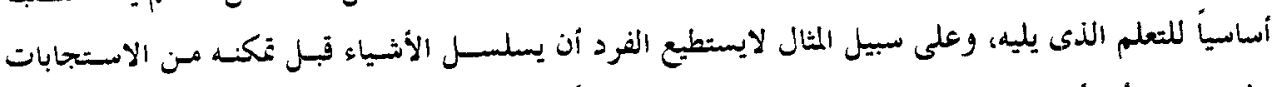

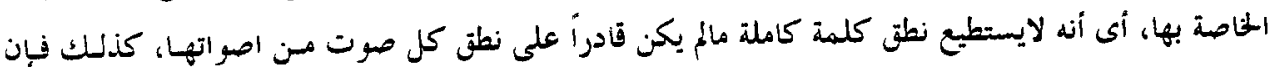

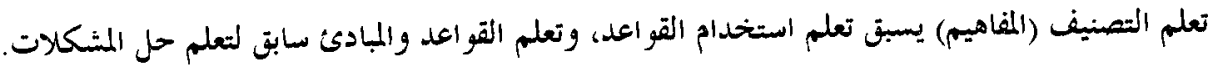

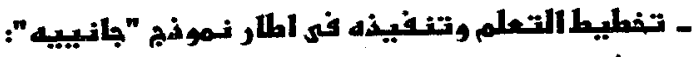

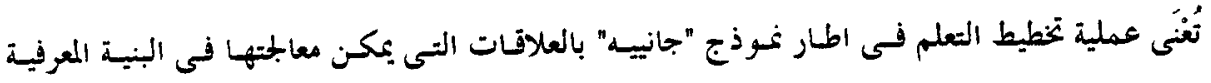

للمتعلم، وتتطلب هذه العملية الحطو ات التالية:

$$
\text { 1- وصف الأهداف أو وصف المهمات التعليمية: }
$$

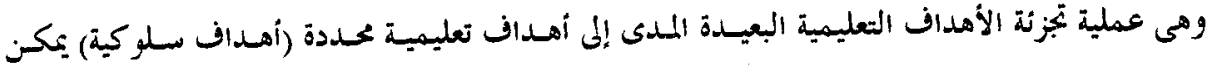

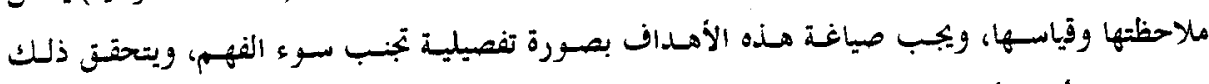

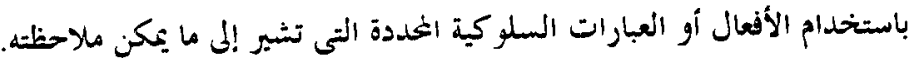

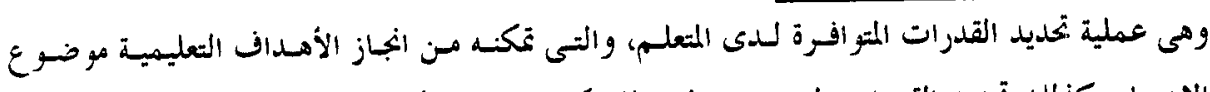
r- تحليزل التعلم (تحليل المهمات التعليمية):

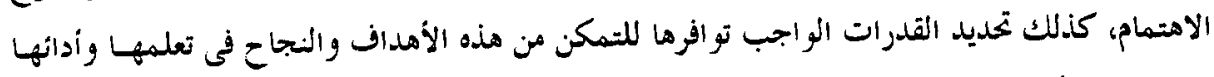

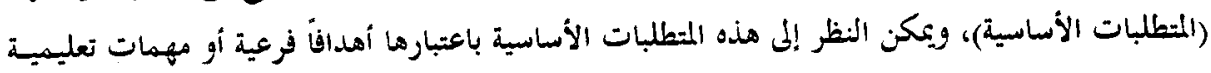

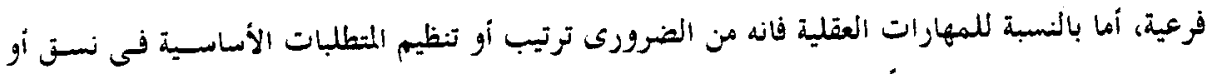
تسلسل هرمى يؤدى تدريياً وخطوة خطوة نحو الهدف المنشود.

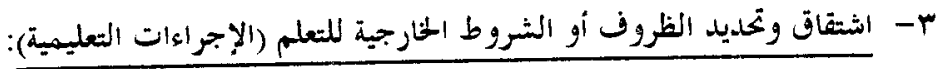

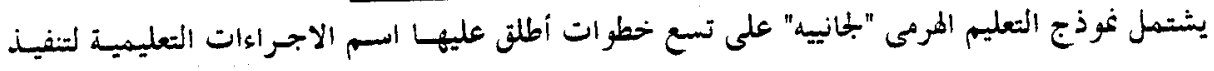

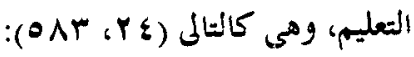

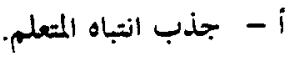
ب- اعلام المتعلم بطبيعة النتانج التعليمية المرغوب فيهاه المبها ج- استثارة القدرة على تذكر المعلوعات أو المططلبات السابقة.

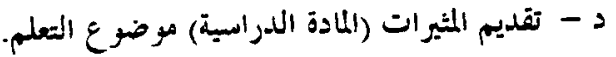




$$
\begin{aligned}
& -515- \\
& \text { هـ- تو جيه المتعلمين عند الحاجة. } \\
& \text { و - تزويد المتعلمين بالتغذية الراجعة المناسبة. } \\
& \text { ز - تشجيع التقدير الذاتى للأذاء. }
\end{aligned}
$$

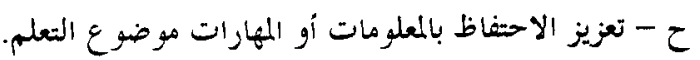

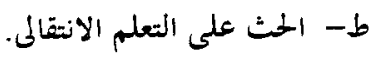

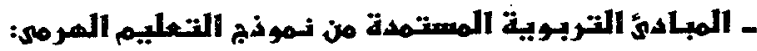

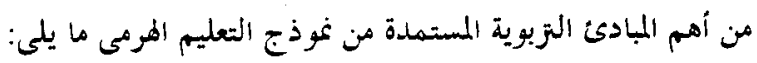

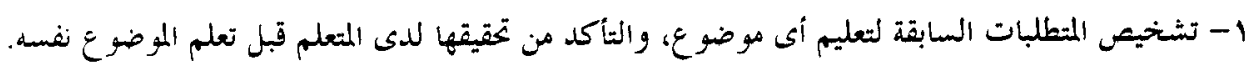

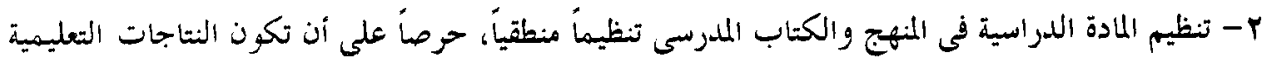

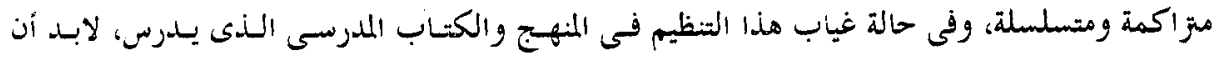

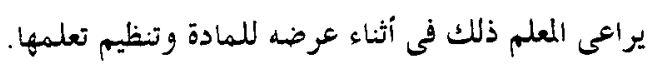

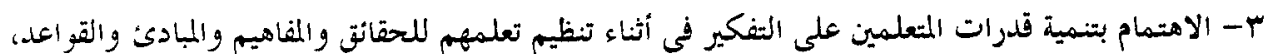

$$
\begin{aligned}
& \text { وتجنب التأكيد على الحفظ. }
\end{aligned}
$$

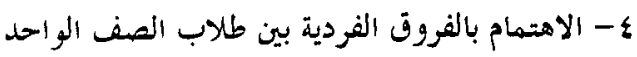

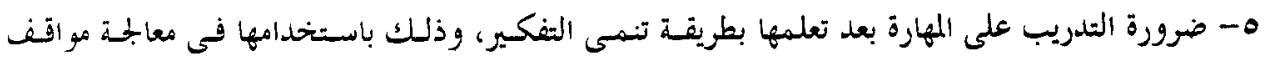

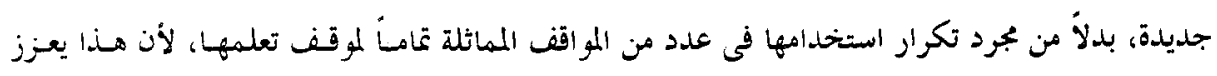
المهارة المتعلمة.

ج- توفير التقويم المرحلى النامى داخل النسق الواحد، للتأكد من تعلم الطلاب للقدرات الدنيا قبـل الإنتقال

$$
\text { إلى تنظيم نشاطات تعليمية للقدرات العليا. }
$$

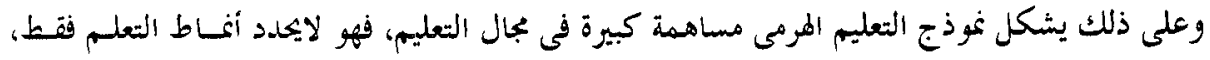

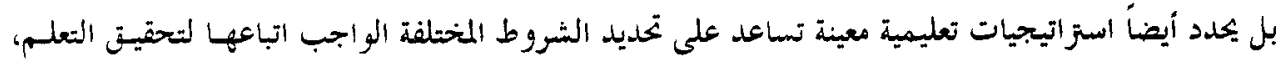

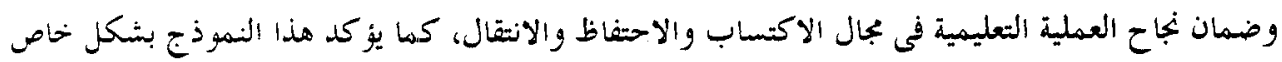

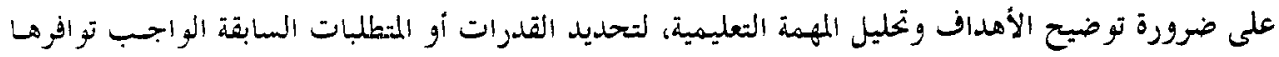

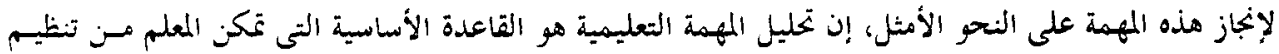

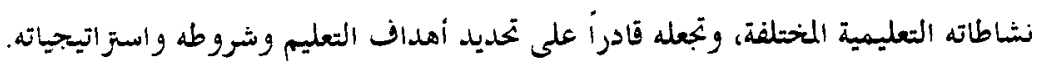




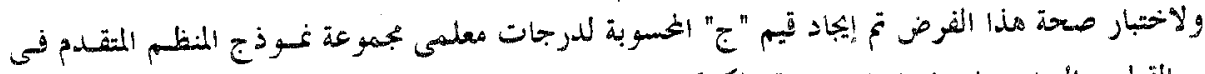

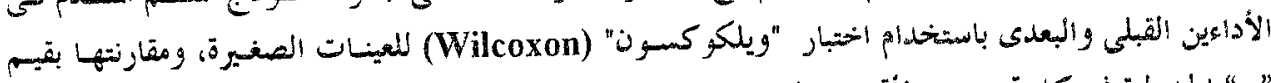

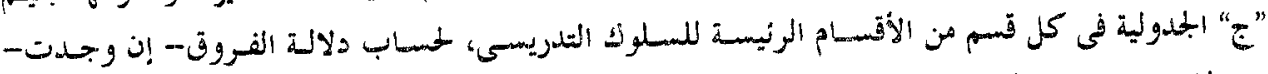

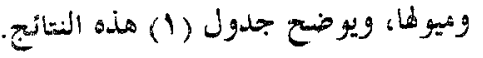

جدول (1)

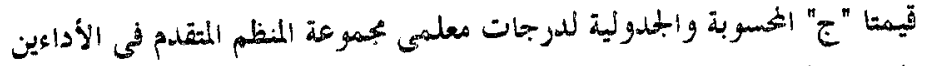

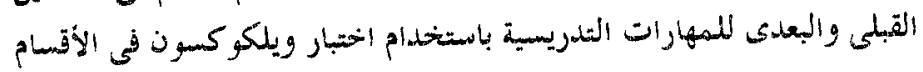

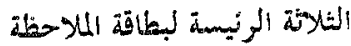

\begin{tabular}{|c|c|c|c|c|c|c|c|}
\hline لصاخ الأدا: & 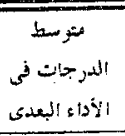 & 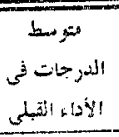 & 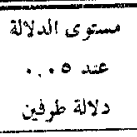 & 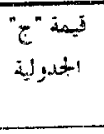 & 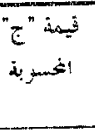 & 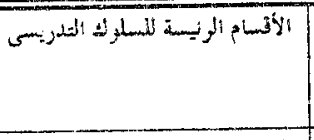 & (3) \\
\hline البعدى & $0, A$ &,+ & دالة & & مفر & التهشيط للتدريس & 1 \\
\hline 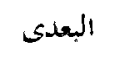 & $17, \%$ & 1. & دالة & 1 & صفيو & تنفيذ المدرونم & $Y$ \\
\hline 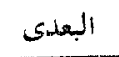 & $r$ & $1, A$ & دالد & & صفر & التقويم & $\psi$ \\
\hline البعلى & $Y 0,1$ & 13,0 & دا & 1 & ميفر & المهارات التسريسية ككل & 4 \\
\hline
\end{tabular}

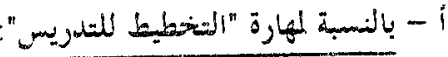

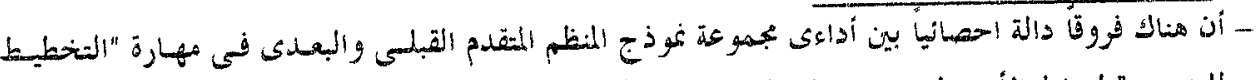

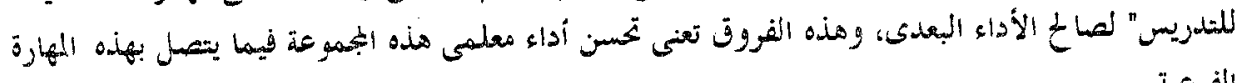
الفوعية.

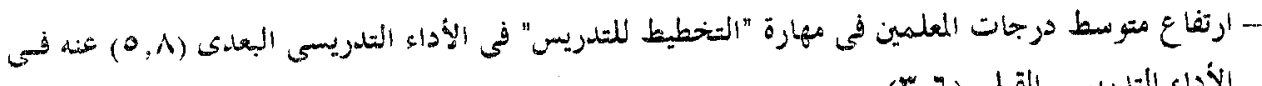

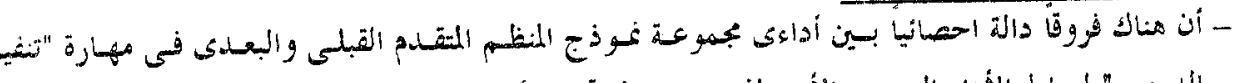

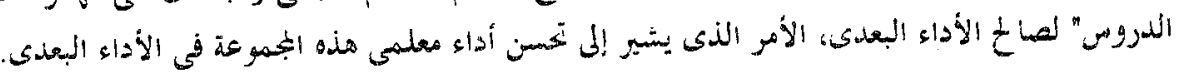

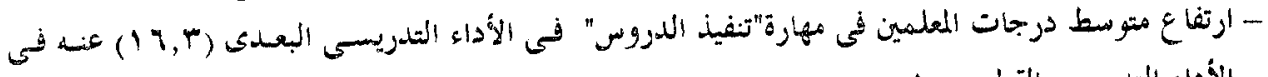

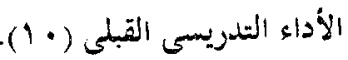




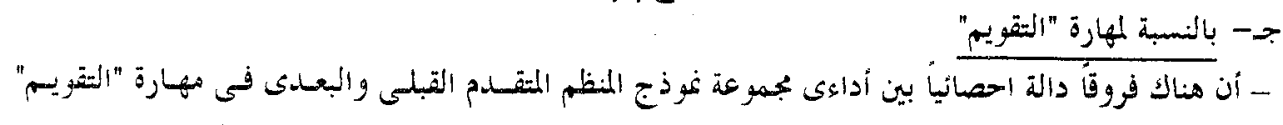

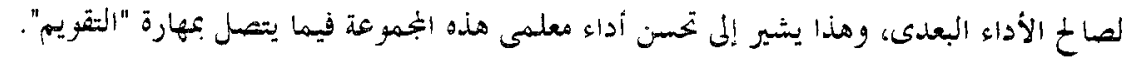

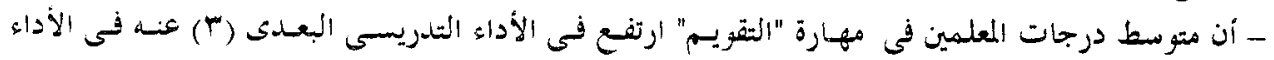

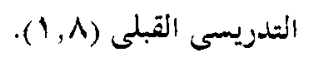

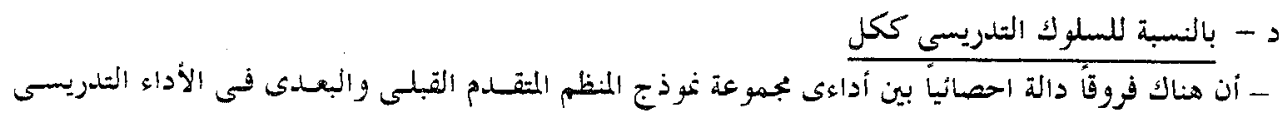

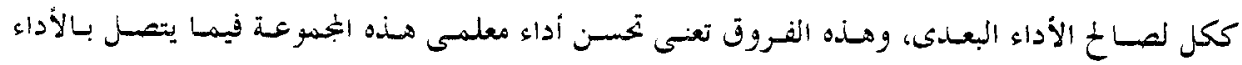
التدريسى ككل. - أرتفاع متوسط درجات المعلدين فى الأداء التدريسى ككل فى الأداء البعدى (1) (؟) عند فى الأداء القبلى $\cdot(10,0)$

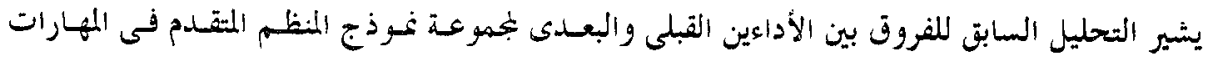

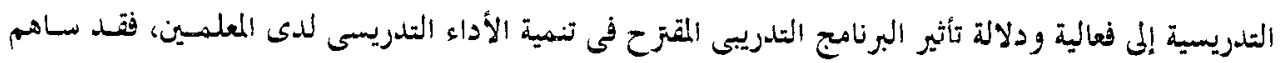

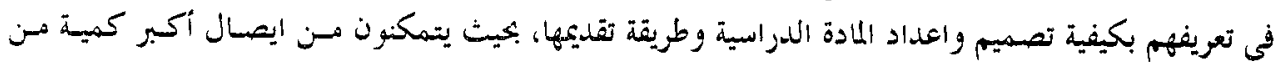

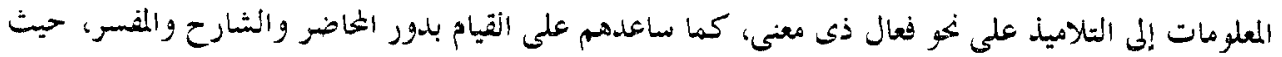

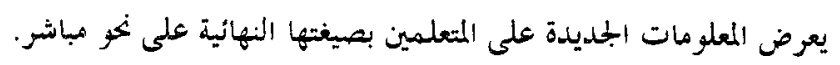

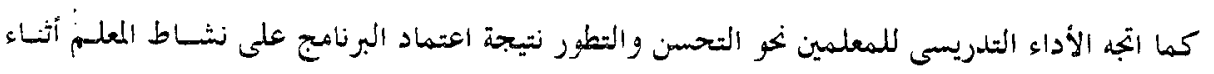

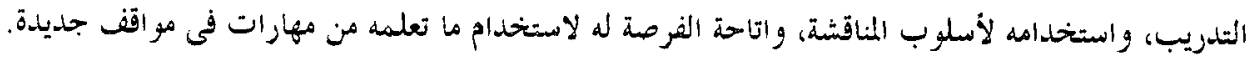

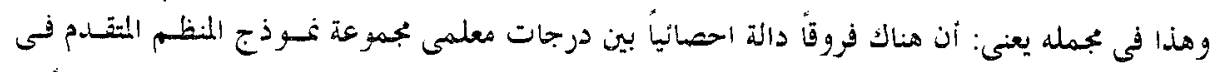

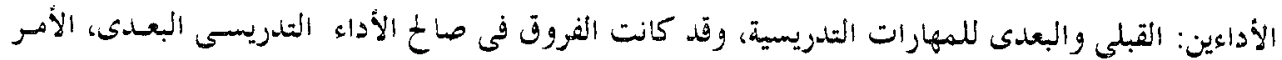
الذى يقود إلى: "رفض الفرض الأول من فروض البحث".

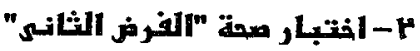

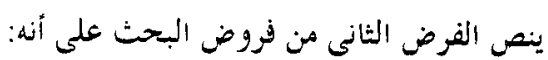

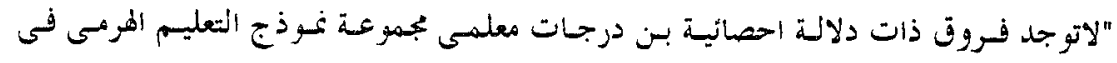

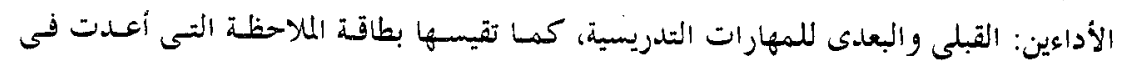
البحث الحالى".

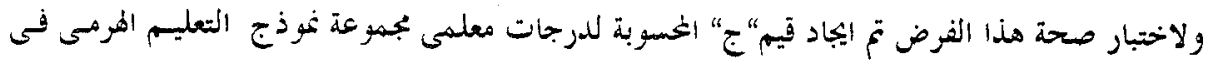

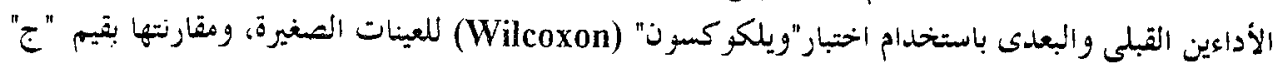

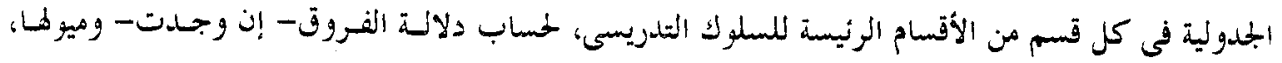
ويوضح جدول (Y) هذه النتائج. 


$$
\text { - }
$$

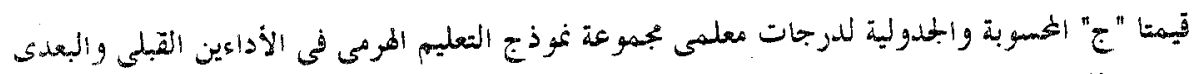

\begin{tabular}{|c|c|c|c|c|c|c|c|}
\hline 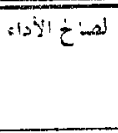 & 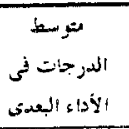 & 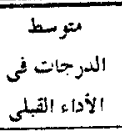 & 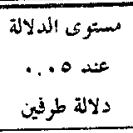 & الجيدةلية "ج" & أخسمة "ج" & 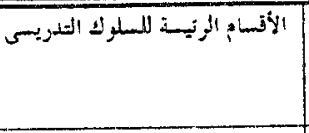 & נis \\
\hline البعدى & $0, \Lambda$ & $\varepsilon, r$ & دالة & & صفر & التخطيط للتدريس & 1 \\
\hline البعدى & IV,O & $1 ., 0$ & دالة & 1 & صفر & تنفيذ اللدروس & Y \\
\hline البعدى ) البعى & $r, V$ & $r$ & دالة & & صفر & التقويمي & 5 \\
\hline البعدى & Y & 19,1 & دالة & 1 & صفر & المهازات التدريسية ككل & \{ \\
\hline
\end{tabular}

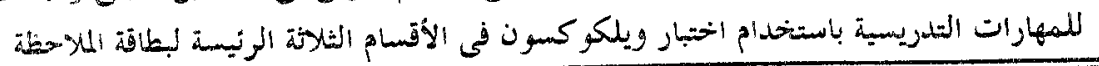

من الجدول السابق بتضحص:

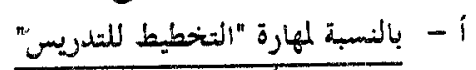

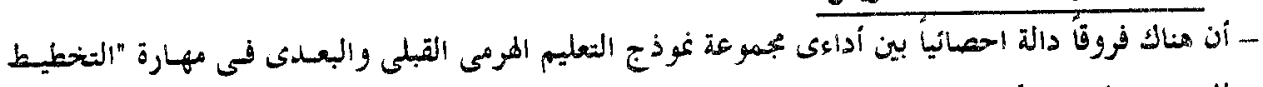

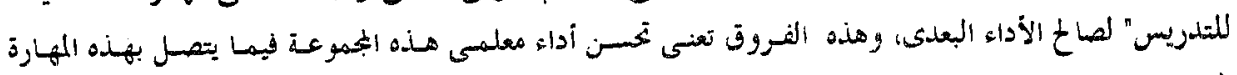
الفرعية.

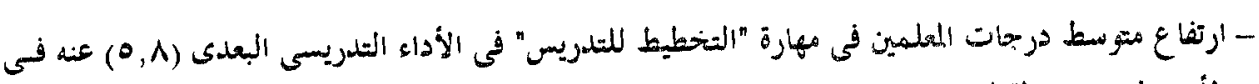

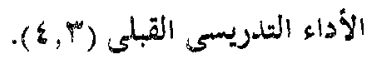

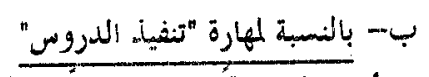

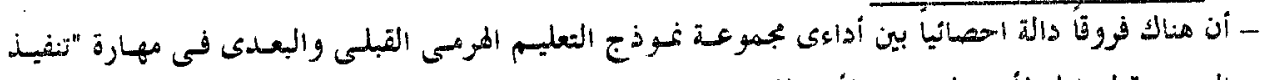

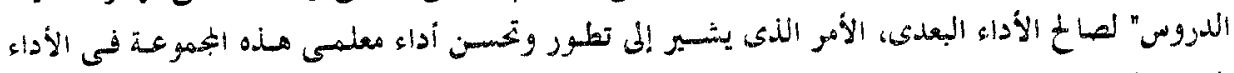

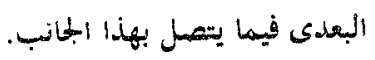

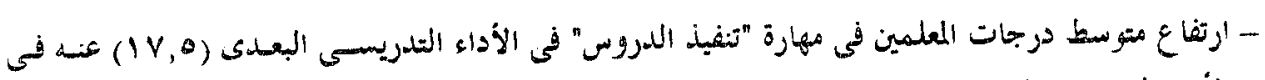

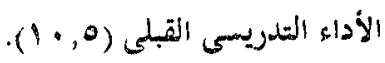

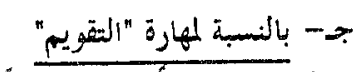

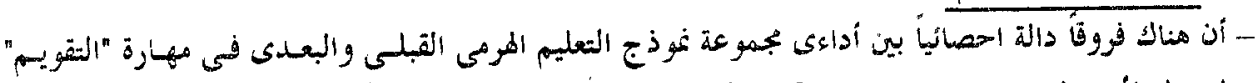

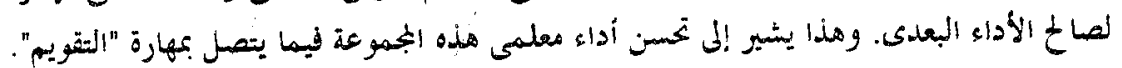

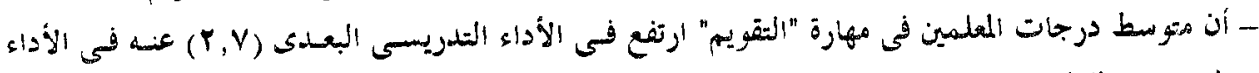

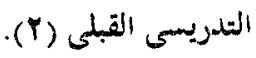

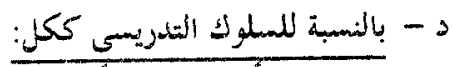

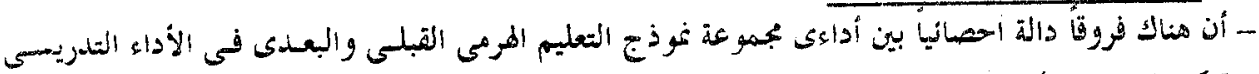

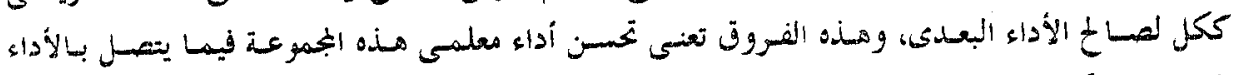

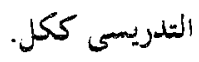

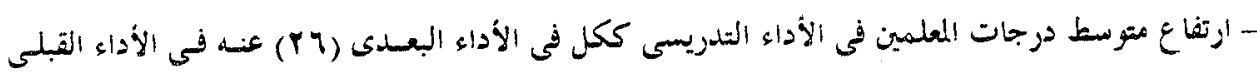




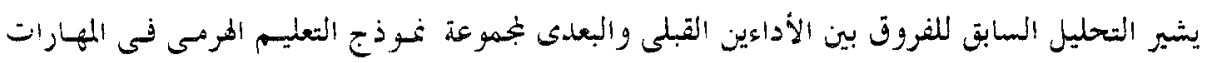

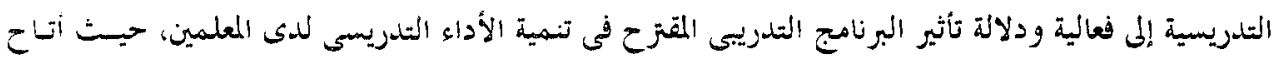

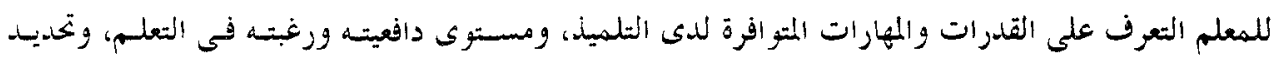

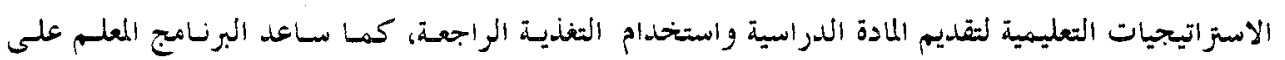

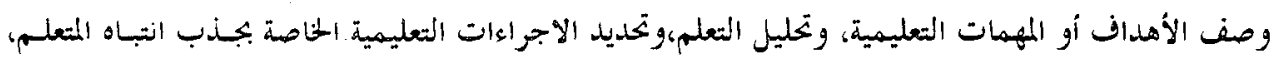

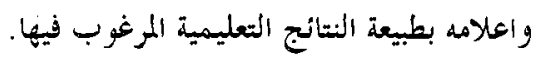

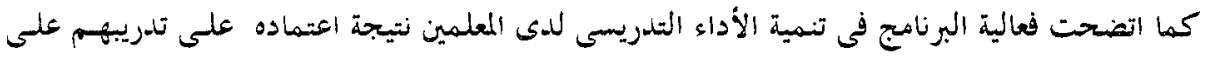

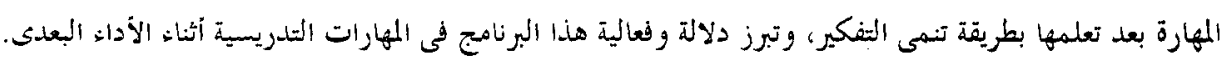

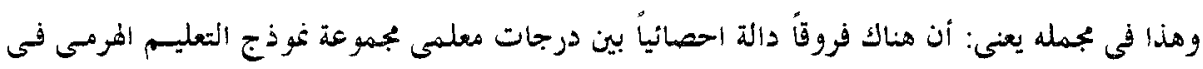
الأداءين: القبلى والبعدى للدهارات التدريسية، وقد كانت الفروق في صالح الأداء التدريسى البعسدى، الأمسر

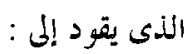

$$
\text { "رفض الفرض الثانى من فروض البحث". }
$$

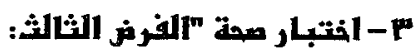

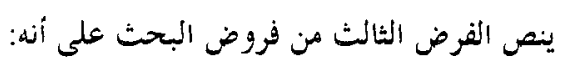

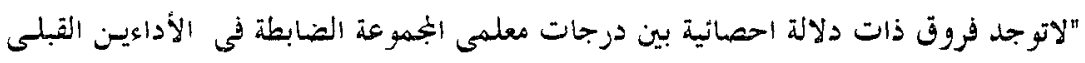

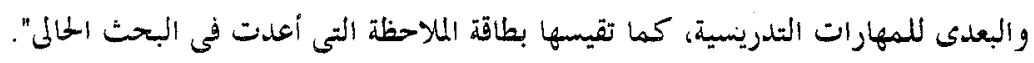

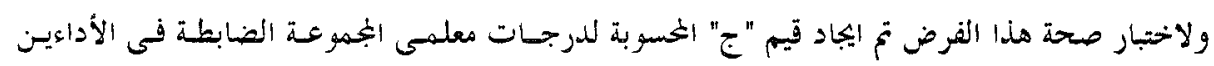

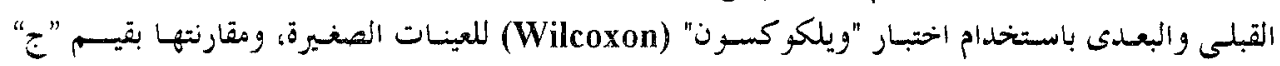

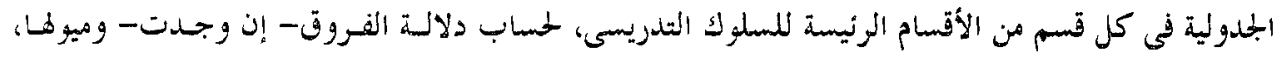

(ب) جلدول

$$
\text { ويوضح جدول (ب) هذه النتائج. }
$$

\begin{tabular}{|c|c|c|c|c|c|c|c|}
\hline لصاخ الأدائ & الأداء البهات في في & الالدزاء المترت فيلى & سلستى الدلالة & الجمدئدة "جية & أخسمونة "ج" & الأتسام الزيسة للسلر كك التلدريسى & is \\
\hline-- & $r, 79$ & $r, \Lambda$ & غير دالة & & $v$ & التخطيط للتدريس & 1 \\
\hline-- & 11 & 9,97 & غير دالة & 1 & $r$ & تنفيذ المروس & r \\
\hline-- & 1,97 & 1,74 & غير دالة & & 0 & التقويم & r \\
\hline-- & $17, r Y$ & 10,19 & غير دالة & 1 & $v$ & المهارات التدريسية ككل & $\varepsilon$ \\
\hline
\end{tabular}

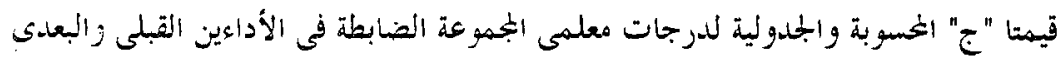

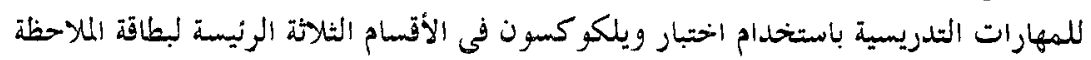

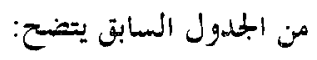




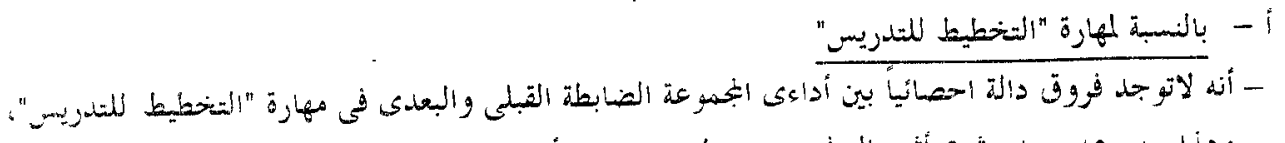

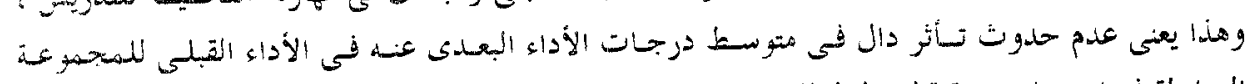

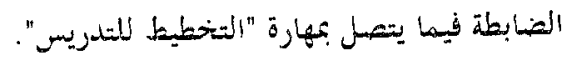

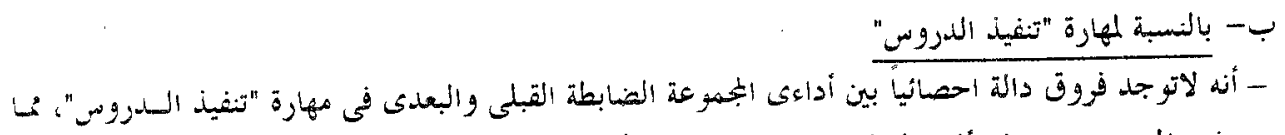

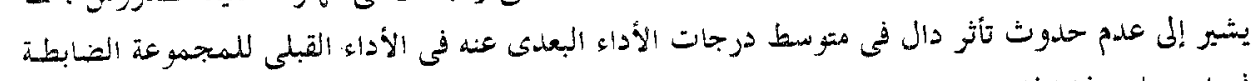
فيما يتصل بهذا الجمانب.

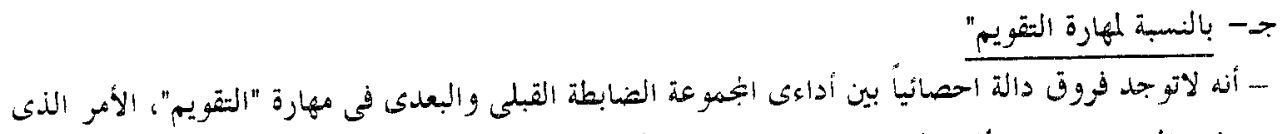

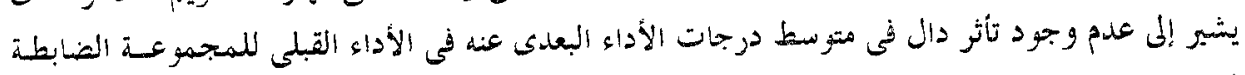
فيما يتصل بهذه المهارة.

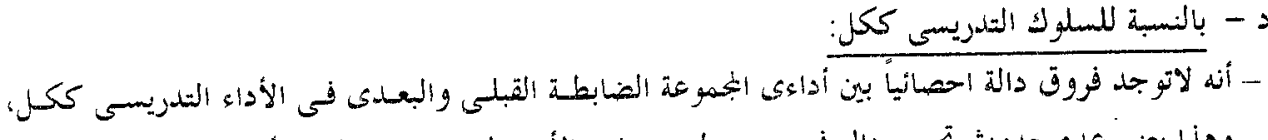

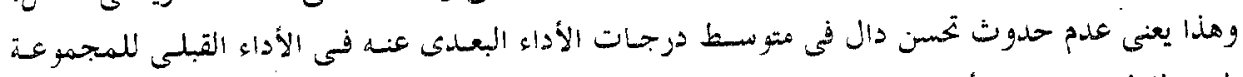

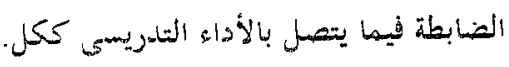

توضح النتائج السابقة للالالة الفروق بين أداءى البحموعة الضابطة التبلى والبعلى في المهارات التدريسية

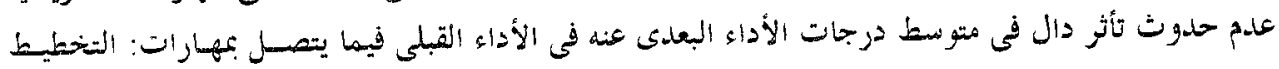

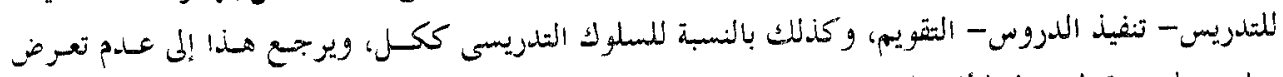

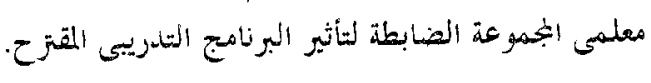

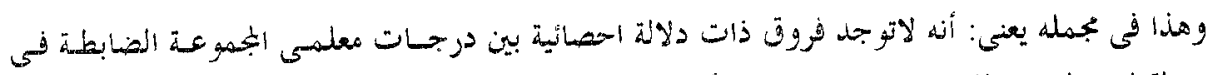

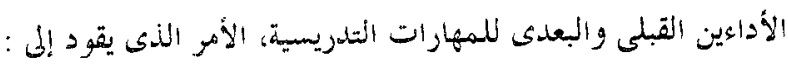

$$
\text { "قبول الفرض الثالث من فروض البحثي". }
$$

ع- انتبار صحة "اللفر غ الرابـر":

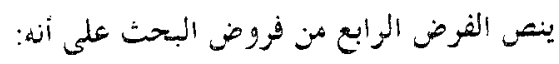

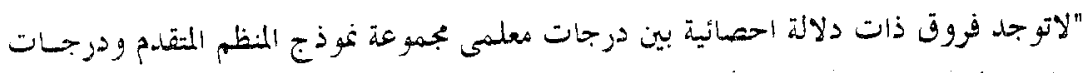

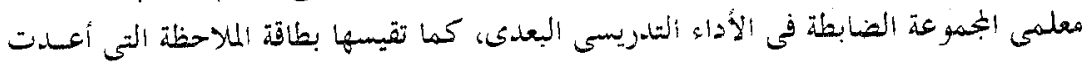

$$
\text { في البحث الحلالي". }
$$

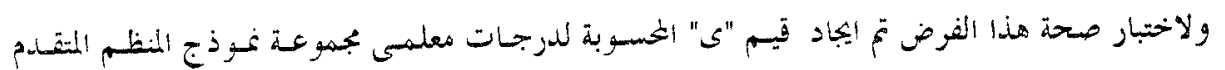

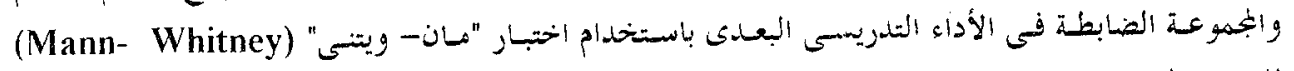

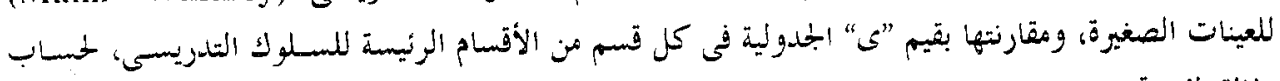

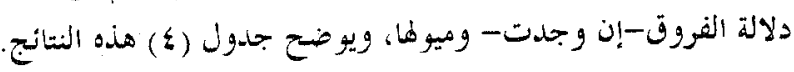




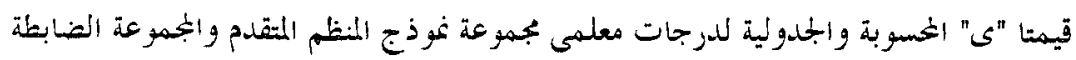

في الأداء التدريسى البعدى باستخدام اختبار مان- ويتنى في الأقسام الثلاكة لبطاقة الملاحظة

\begin{tabular}{|c|c|c|c|c|c|c|c|}
\hline 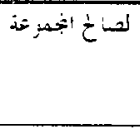 & 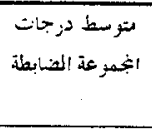 & 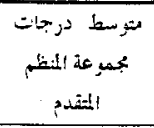 & عسترى الدلالة & تجيدنة "ى" & تيسة "تى" & الأفسام الريسية للسلو ك التلريسى & קהم \\
\hline 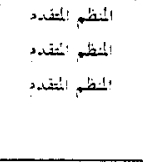 & $\begin{array}{l}5.77 \\
11 \\
1.77\end{array}$ & $\begin{array}{c}\bullet, \wedge \\
17, r \\
r\end{array}$ & دالة & 0 & صفر صفر & التخطيط التفيذ المدروس & $\begin{array}{l}r \\
r\end{array}$ \\
\hline 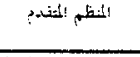 & IY,YY & Yo, & دالة & 0 & صفر & المهارات التدريسية ككل & $\varepsilon$ \\
\hline
\end{tabular}

من الجلدول السابق يتضح:

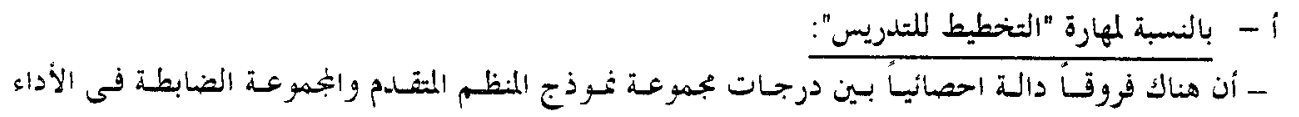

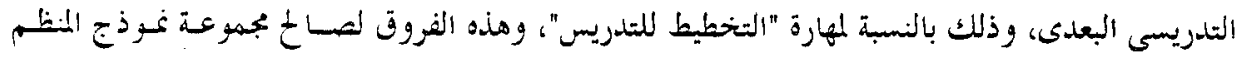

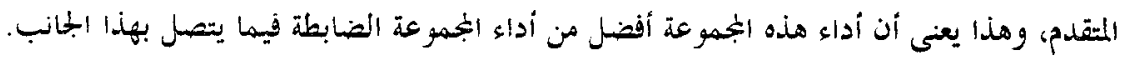

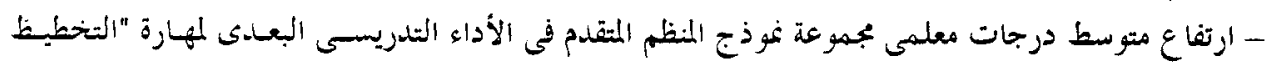

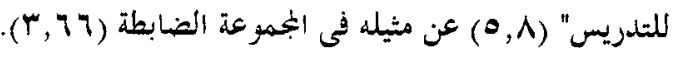

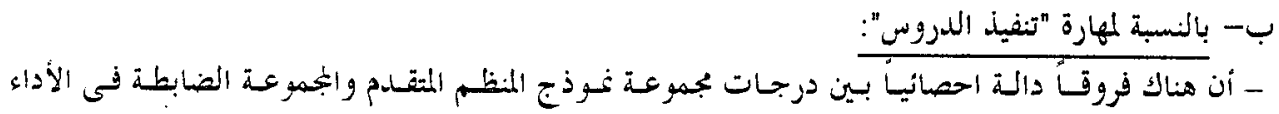

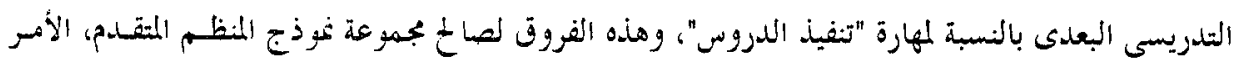

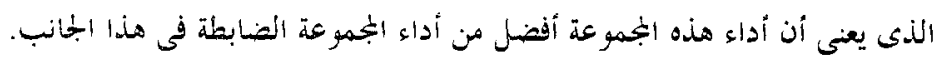

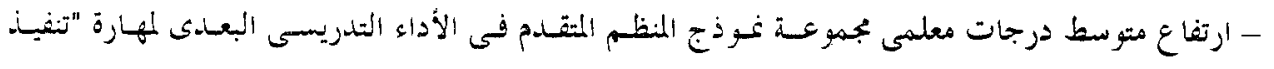

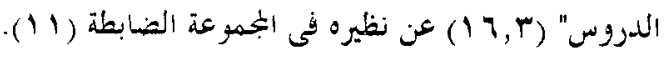
- جـ- بالنسبة لمهارة "التقويم":

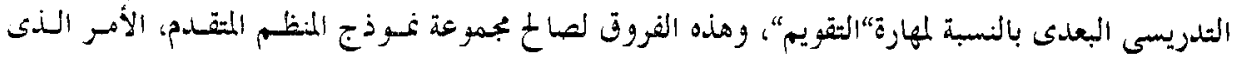

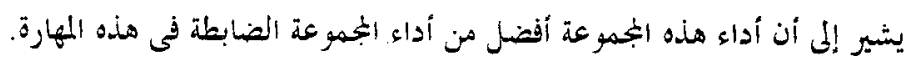

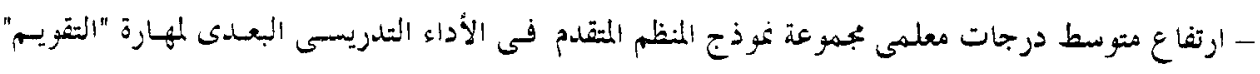

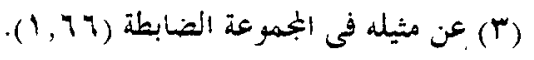

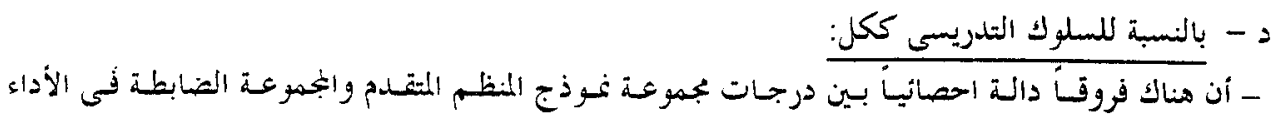

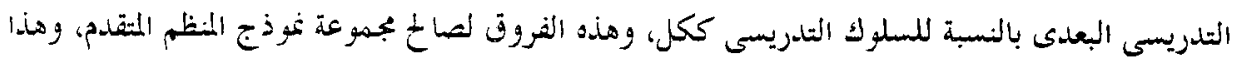

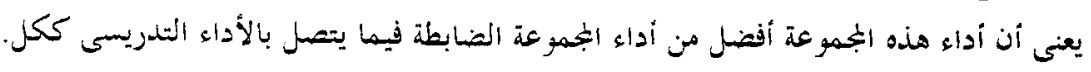




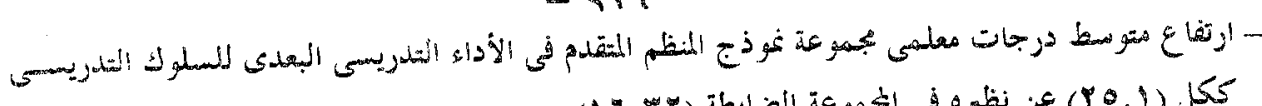

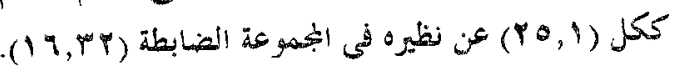

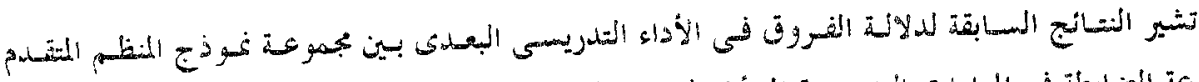

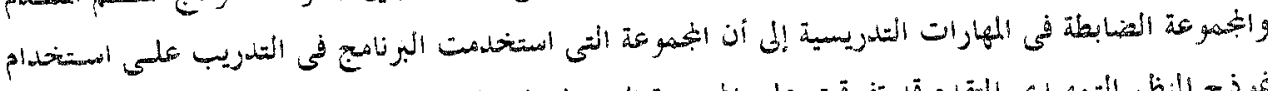

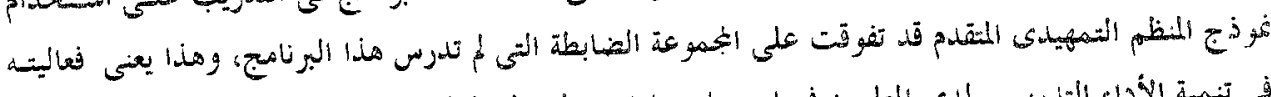

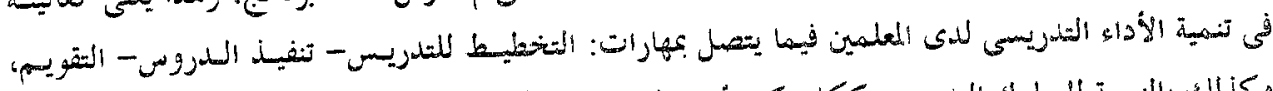

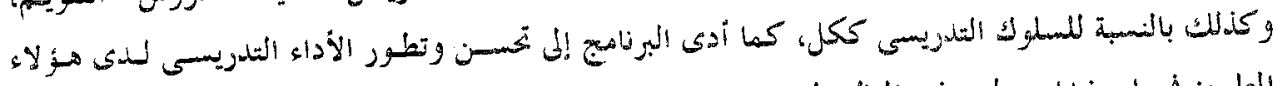

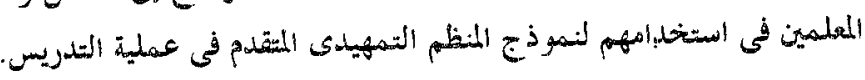

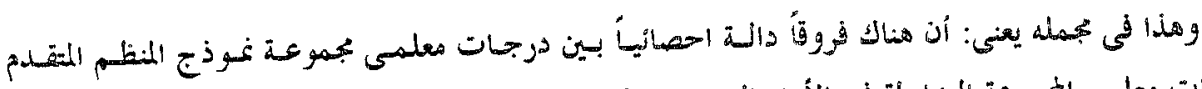

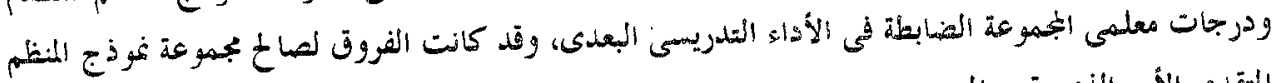

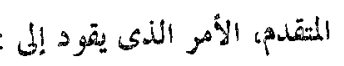

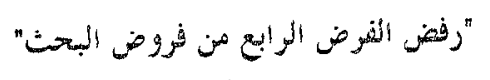

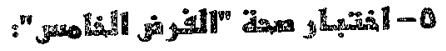

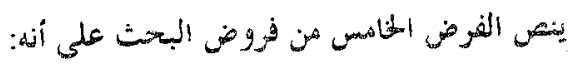

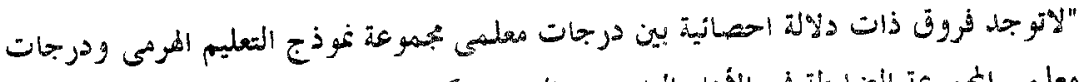

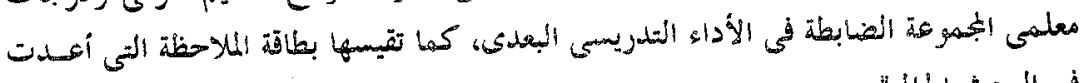

$$
\text { في البحث الحلالي". }
$$

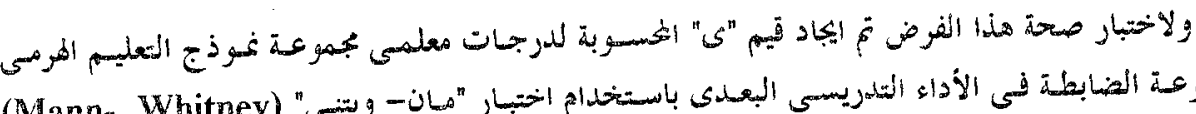

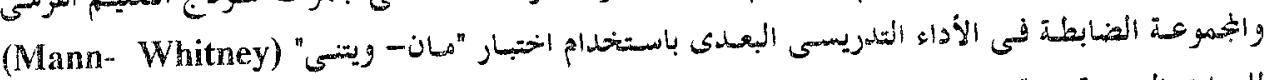

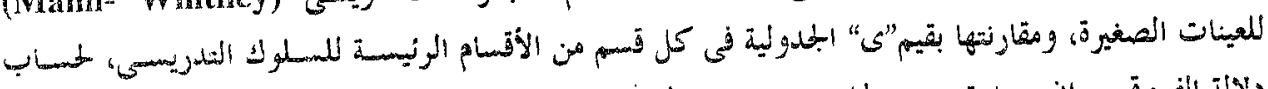

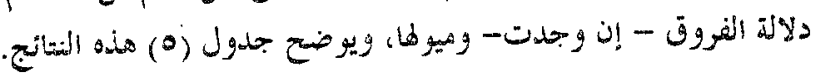

\section{(ब) جلمول}

\begin{tabular}{|c|c|c|c|c|c|c|c|}
\hline لهاح الخهر شئة & 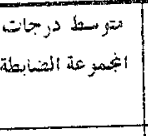 & مجدوعة الكعليم & 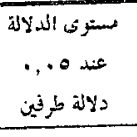 & "الجدرية لية" & "نيمسة "ى" & الأقسام الرنيسة للسلو كي الثلديسي & رتم \\
\hline \multirow{3}{*}{ 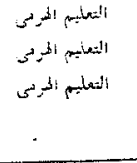 } & $r, 77$ & $\bullet, A$ & دالة & \multirow{3}{*}{ 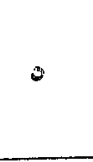 } & صفر & | التخطيط للتدريس & 1 \\
\hline & 11 & $i Y, 0$ & دالة & & صفر & | تنفيذ الدروس & r \\
\hline & 1,79 & $Y, Y$ & دالة & & صفر & التقويم & $r$ \\
\hline 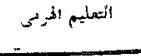 & $17, \% 4$ & YY & دالة & 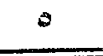 & صفر & المهارات التلدريسية ككل & $\varepsilon$ \\
\hline
\end{tabular}

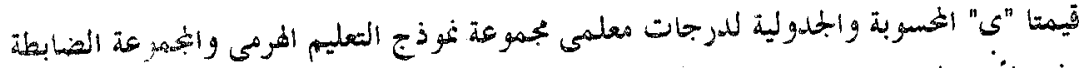

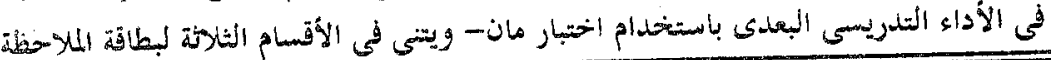




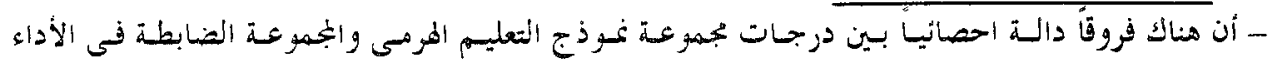

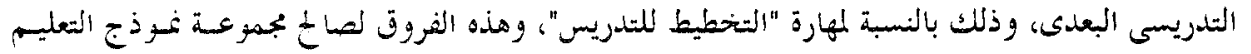

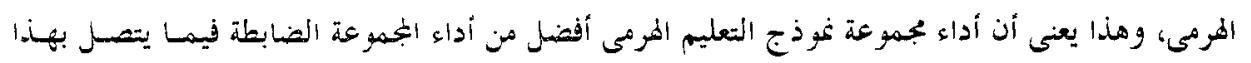
البلبانب.

- ارتفاع متوسط درجات معلمى بمجموعة نموذج التعليم المرمى فى الأداء الثدريسى البعسدى لمهارة "التخطيط

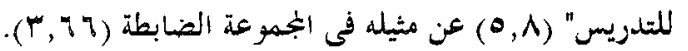

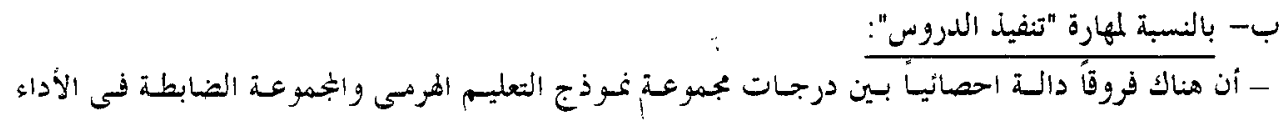

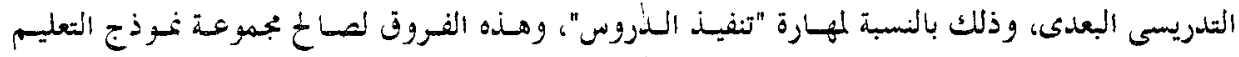

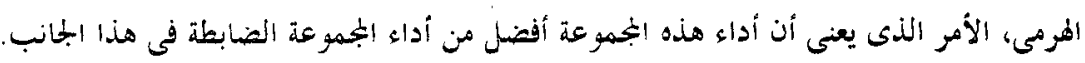

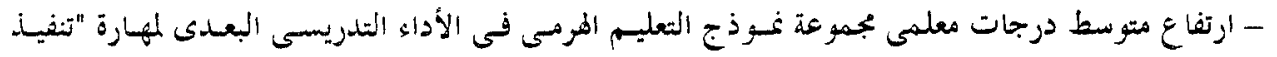

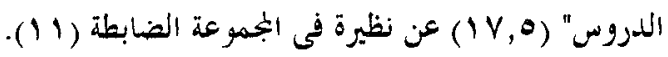

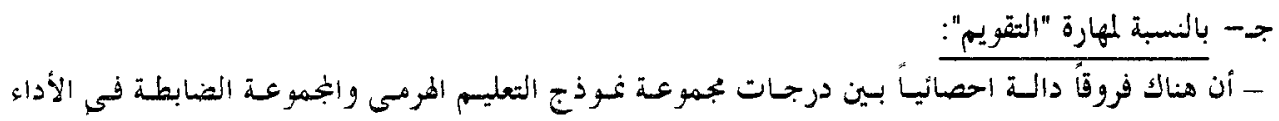

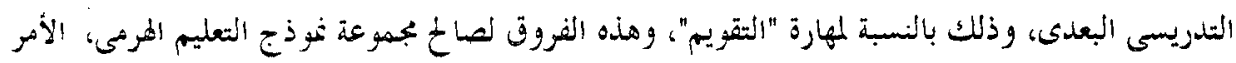

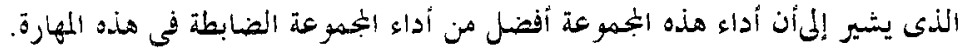

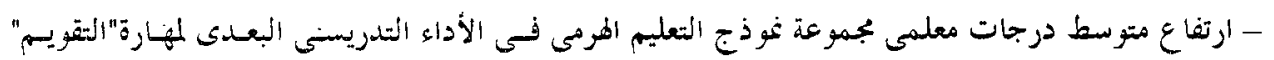
(T,V)

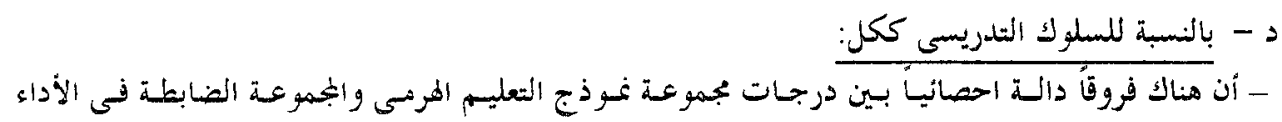

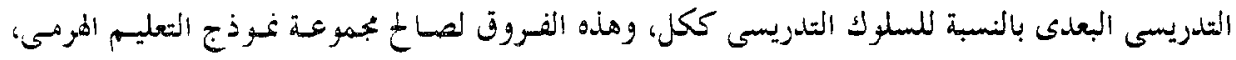

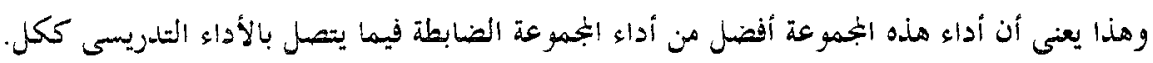

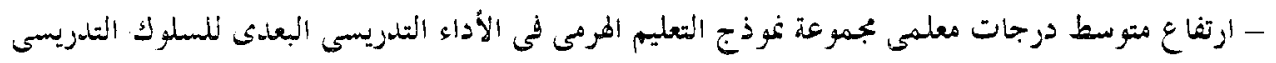

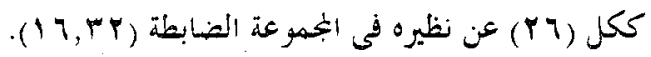

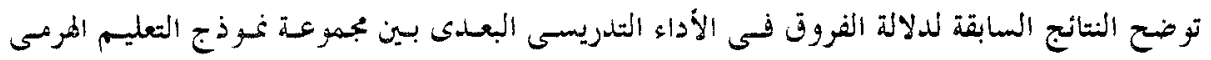

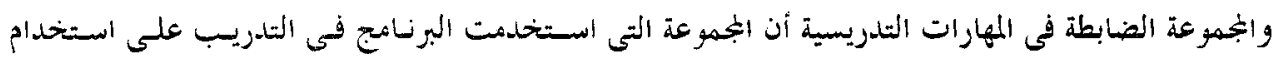

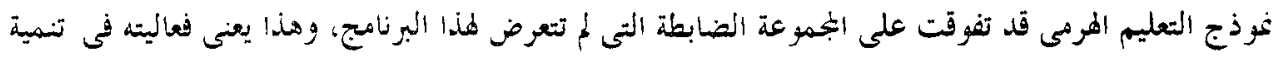

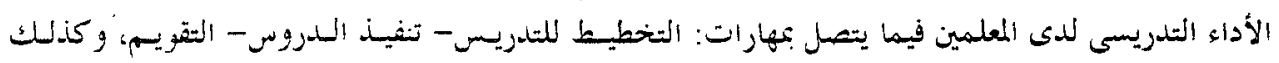

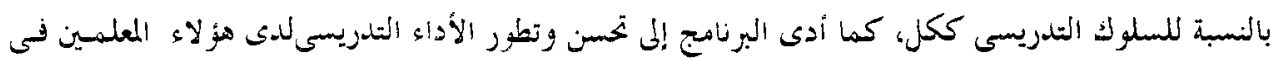
استخدامهم لنموذج التعليم افرمى فى عملية التلدريس. 


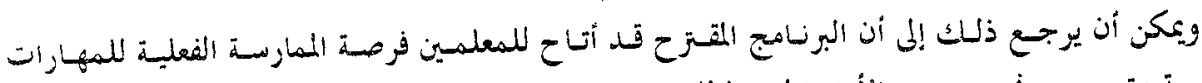

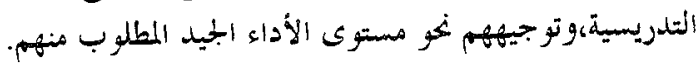

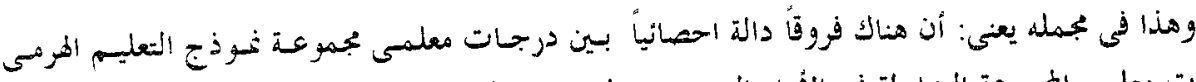

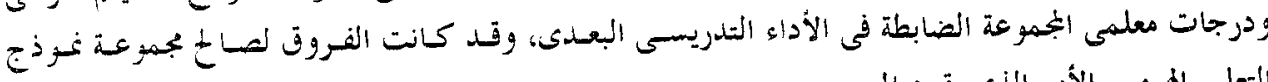

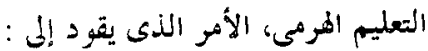

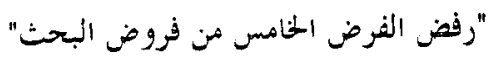

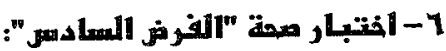

ينص الفرض السادس من فروض البحث غلى أنها:

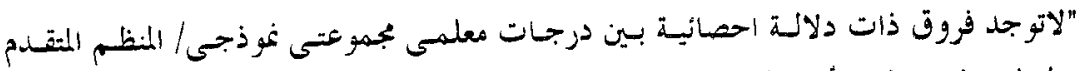

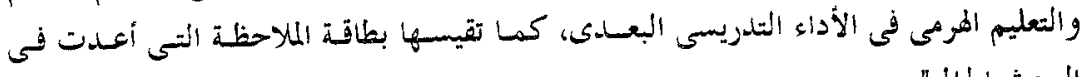

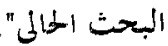

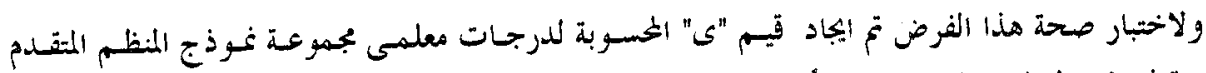

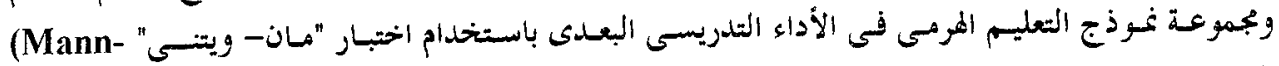
Whitney)

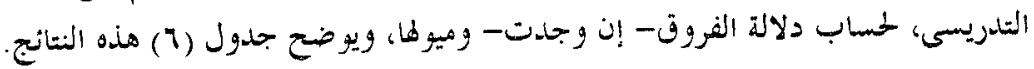
(7) جدول

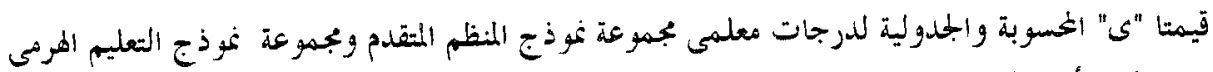

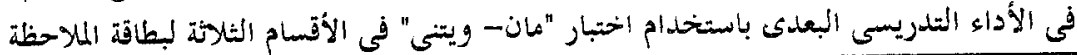

\begin{tabular}{|c|c|c|c|c|c|c|c|}
\hline لصالح انخموثة & لجمورعة العليميم & 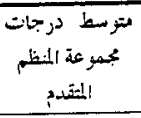 & 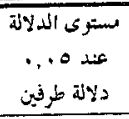 & "الجديمولية" & 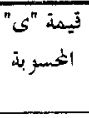 & الأقسام الرٔنيسة للسلولك التلدريسي & נ35 \\
\hline- & $0, \Lambda$ & 0,1 & غير دالة & & 10 & التخطيط للتدريس & 1 \\
\hline 一 & $I V, \theta$ & 14.5 & غير دالة & 0 & 18 & تنفيذ الدروس & $Y$ \\
\hline - & $Y, Y$ & r & غير دالة & & 10 & التقويم & $r$ \\
\hline - & 99 & $Y 0,1$ & غير دالة & 0 & 19 & المهارات التدريسية ككل & $\varepsilon$ \\
\hline
\end{tabular}

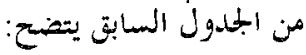
أ - بالنسبة لمهارة "التخطيط للتندريس" السيقي"

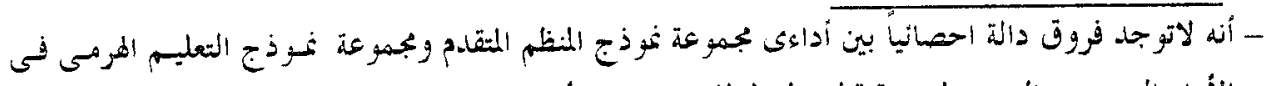

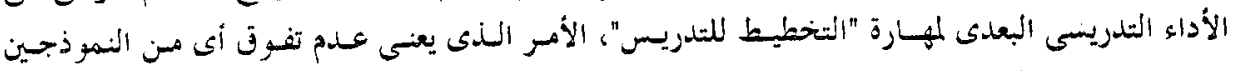

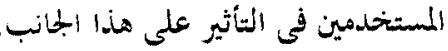
- ويلاحظ أن متوسط درجات المعلمين فى مهارة "التخطيط للتدريس" في كلتا البحموعتين متقارب جلدأ. 


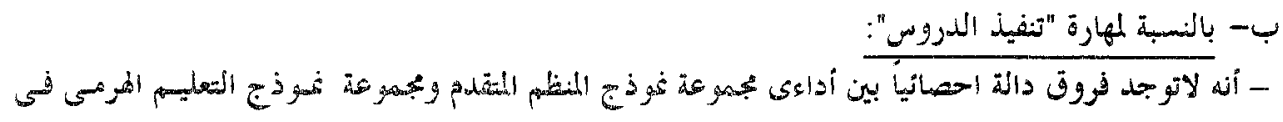

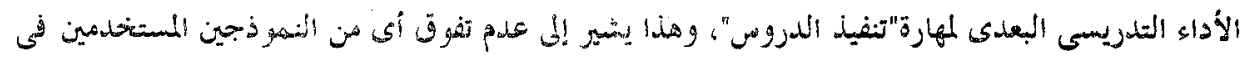

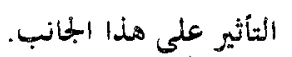

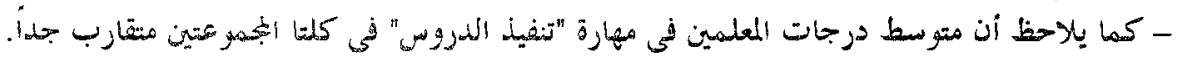

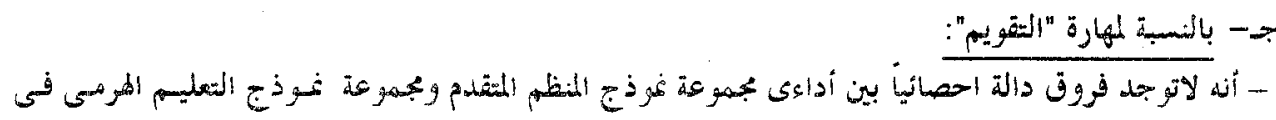

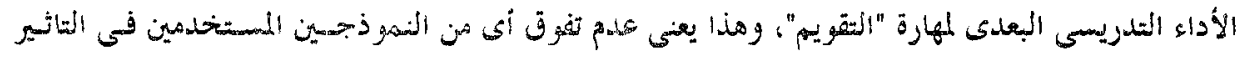
على هذا البلحانب. - ويلاحظ أن متوسط درجات المعلمين في مهارة "التقويم" في كلتا الجختهوعتين متقارب جلداً:

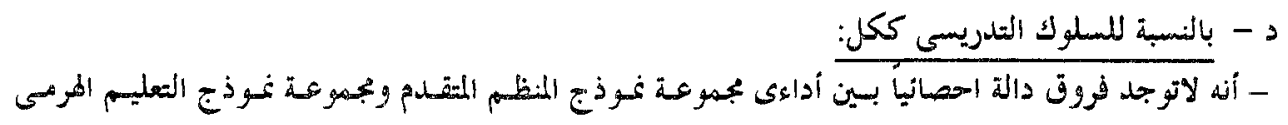

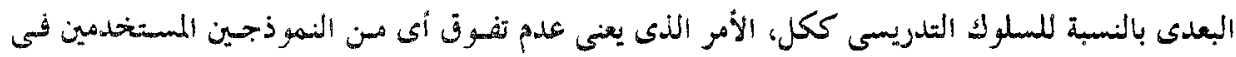
التأثير على هذا الجمانب.

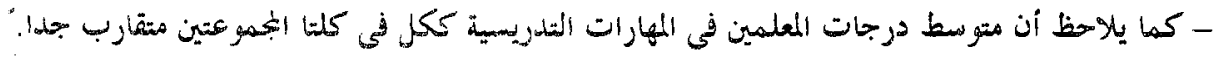

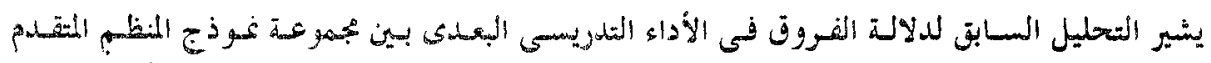

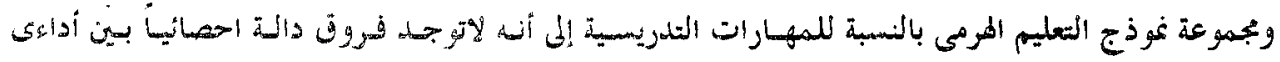

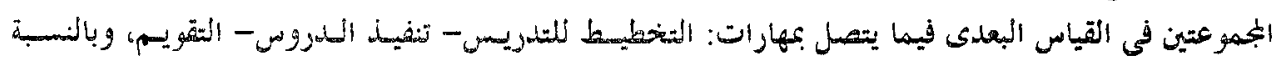

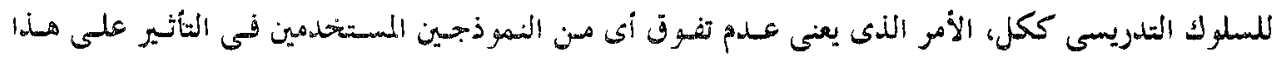

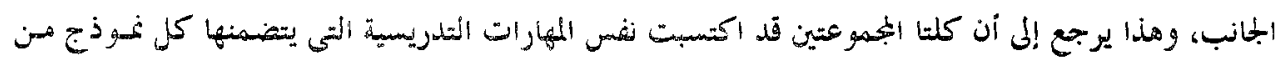

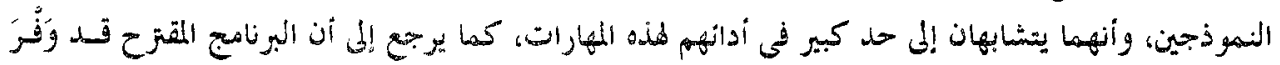

$$
\text { فرص تلدريب متساوية لكلتا المجموغتين. }
$$

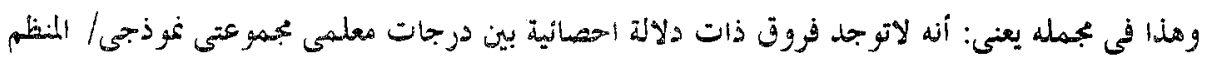

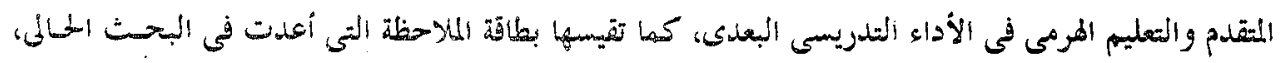

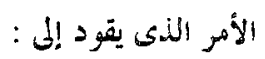

"قبول النفرض السادس من فروضز البحث"

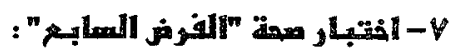

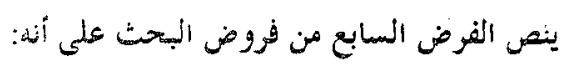

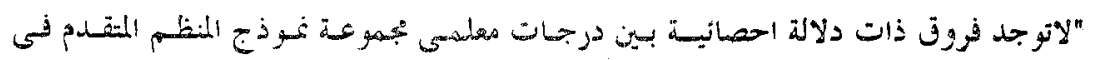

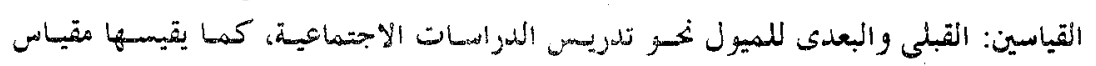

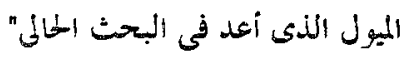




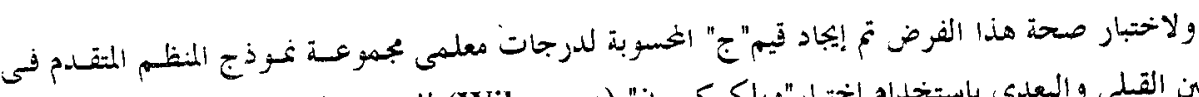

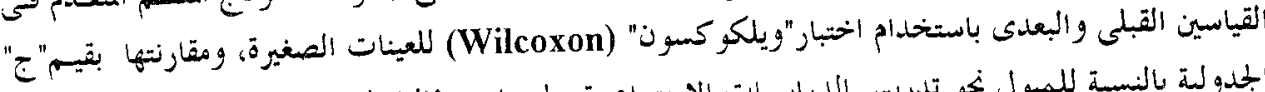

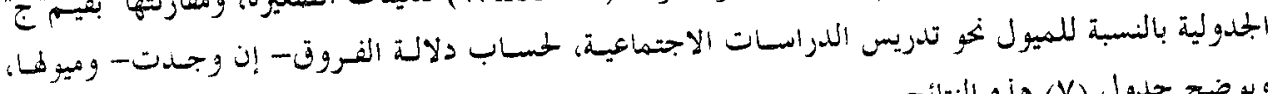
ويوضح جدول (V) هذه النتائج.

$$
\text { (V) جلدول }
$$

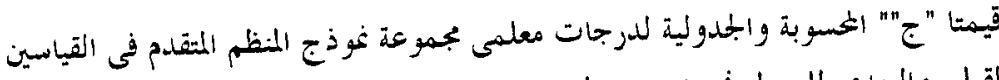

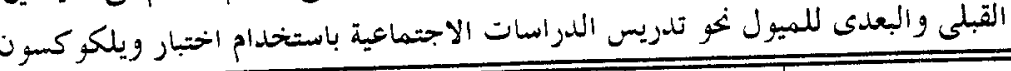

\begin{tabular}{|c|c|c|c|c|c|c|}
\hline لصاح القياس & الدرجزات نى & الدرجات في & عذس ه .,. & لفيمة "ج" الجدرلية & "نيمة "ح" & الييان \\
\hline البعدى & $9 Y, O$ & 09 & دالة & 1 & صفر & الاجتيولماعية نـو تدريس الدراسـات \\
\hline
\end{tabular}

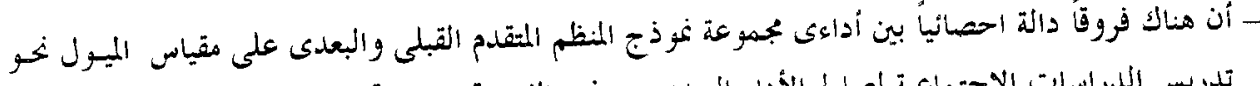

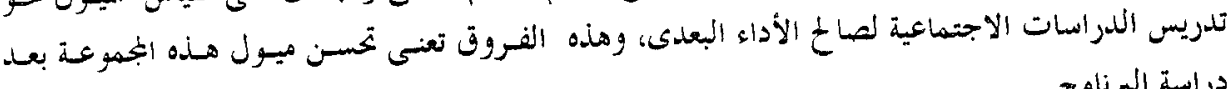

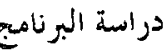

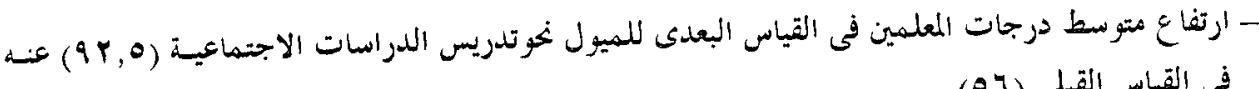

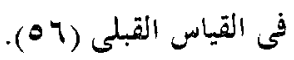

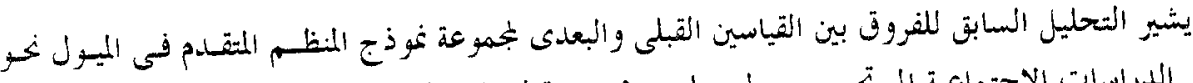

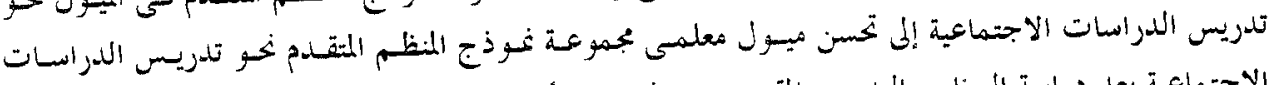

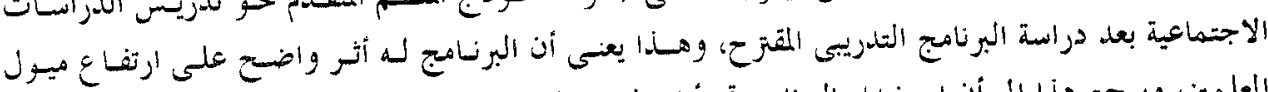

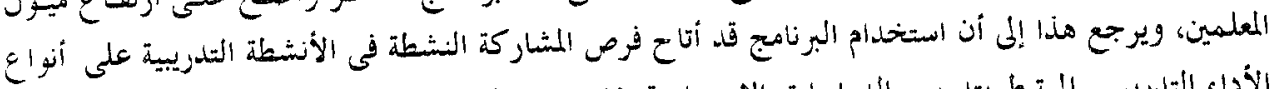

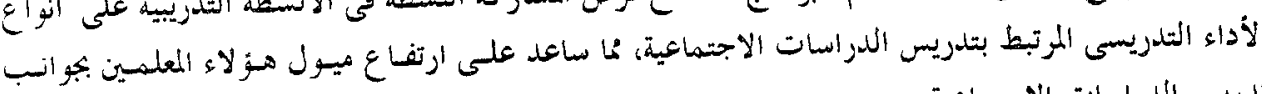
تدريس اللدراسات الاجتماعية.

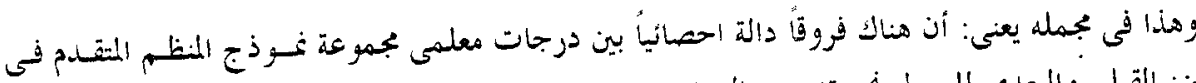

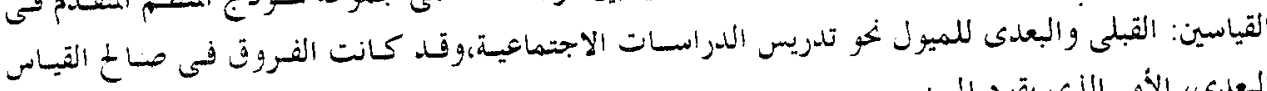

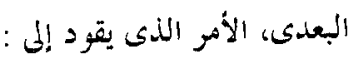

$$
\text { "رفض الفرض السابع من فروض البحث". }
$$

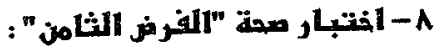

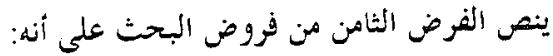

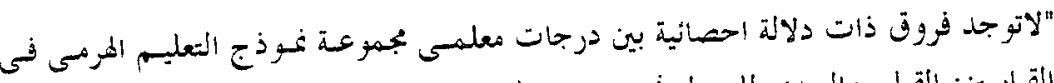

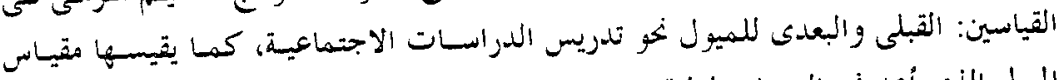
الميول الذى أعدد في البحث الملايلي". 


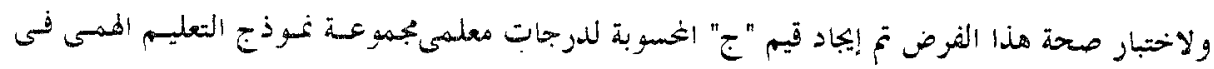

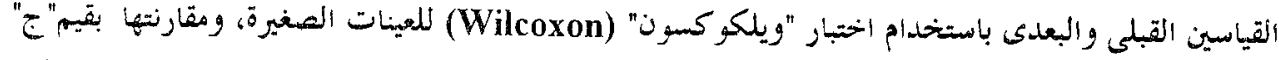

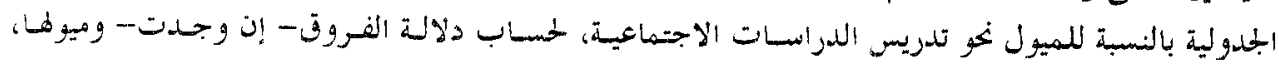
ويوضح جدول (^) هذه النتائج.

(^) جدول

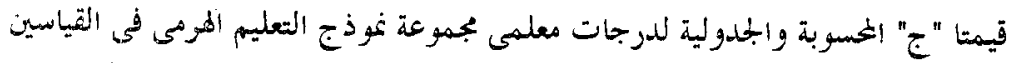

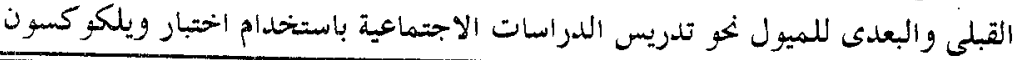

\begin{tabular}{|c|c|c|c|c|c|c|}
\hline 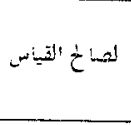 & 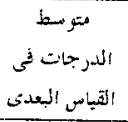 & 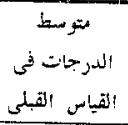 & 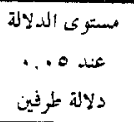 & "المديمنية "ج" & 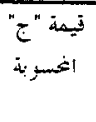 & البيان \\
\hline البعأى & $9 \leq, 9$ & $\{Y, 7\rceil$ & دالة & 1 & صفر & 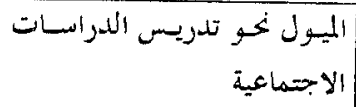 \\
\hline
\end{tabular}

من الجلدول السابق يتضح:

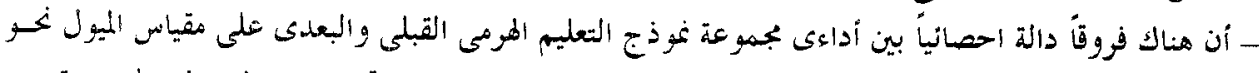

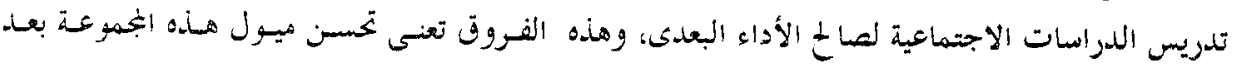
- ارتفاع متوسط درجات المعلمين فى القياس البعدى للميول نحو تلدريس المدراسات الاجتسماعية (1, ؟ ج) عنسه

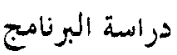

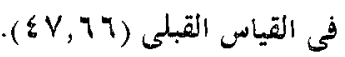

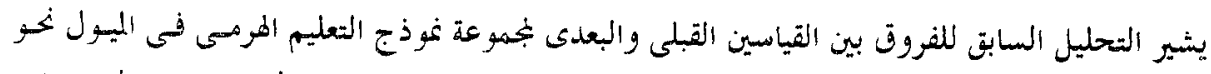

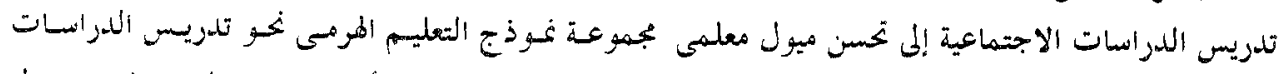

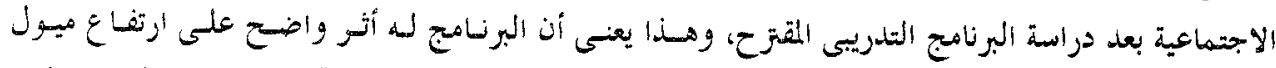

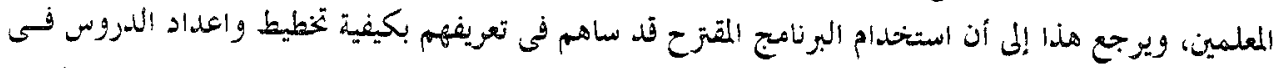

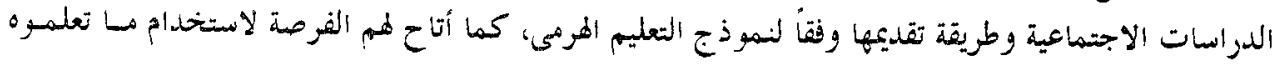

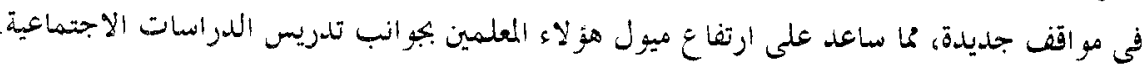

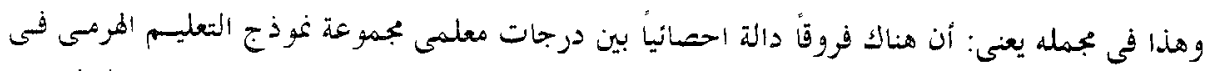

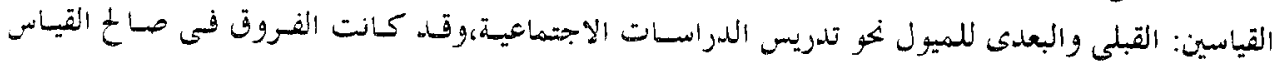

البعدى، الأمر الذي يقود إلى :

"رفض الفرض الثامن من فروض : البحث".

9- آذتبار صفة "الفرم الناسعر":

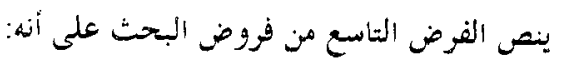

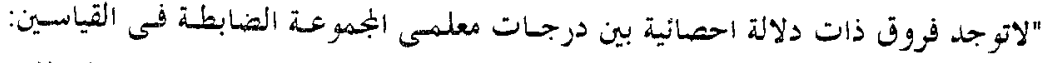

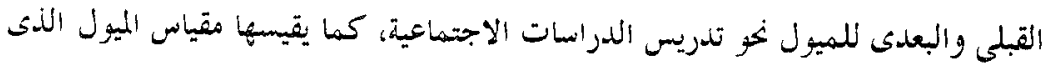

أعد في البحث الملالي". 


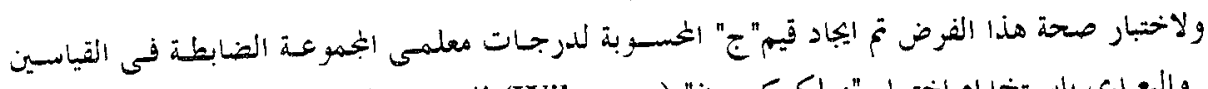

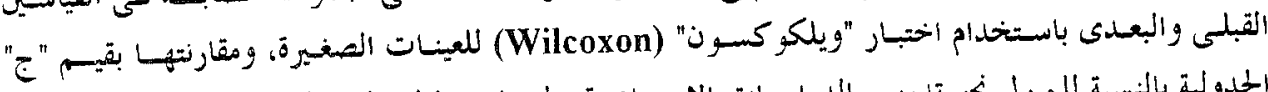

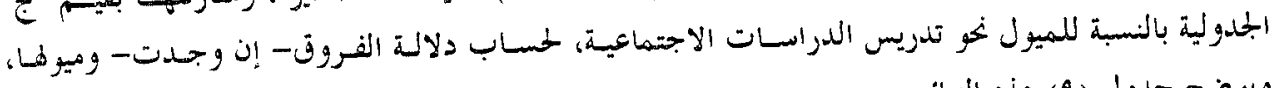
ويوضح جدول (q) هذه النتانج.

جدول (9)

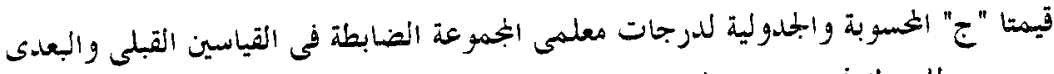

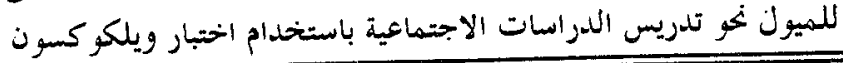

\begin{tabular}{|c|c|c|c|c|c|c|}
\hline لصاخ التينس & القياس البعدى في & القدربات القيلى & عستوى الدلالة & الجيمة "ج" & الخسربة "ج" & اليان \\
\hline - & OV,Ar & $0\{, 17$ & غير دالة & 1 & 1 & 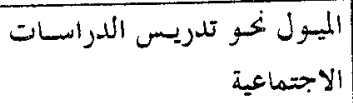 \\
\hline
\end{tabular}

من الجدول السابق يتضح:

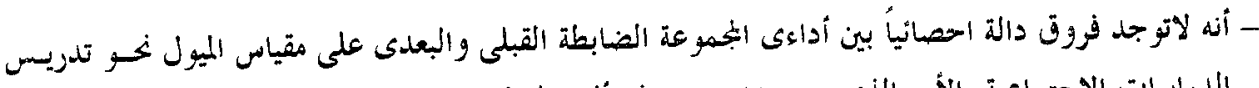

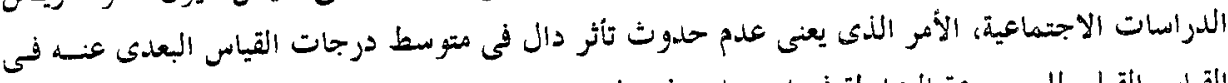

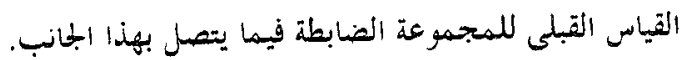

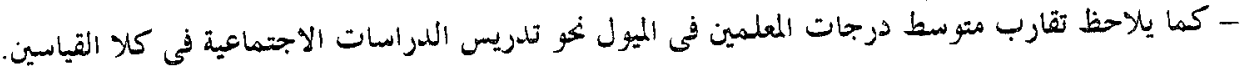

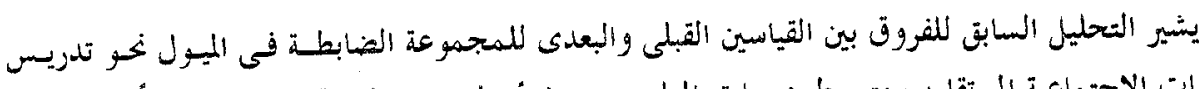

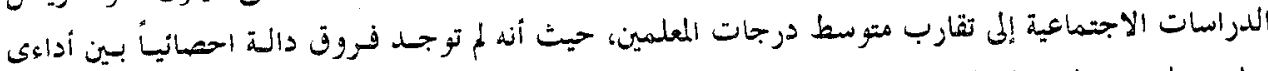

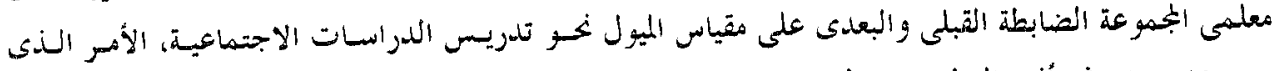

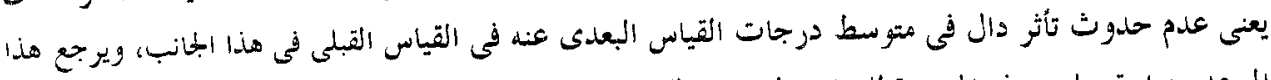

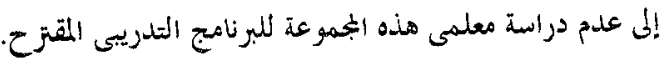

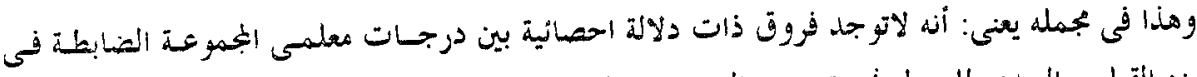

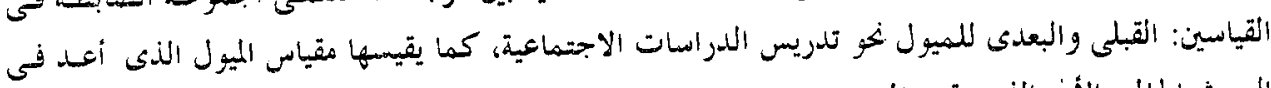

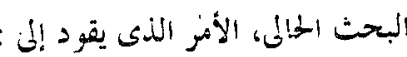
"قبول الفرض التاسع من فروض البحث".

•l- الختبار صحة "الفر مر العاشر ": ينص الفرض العاشر من فروض البحر البحث على أنه:

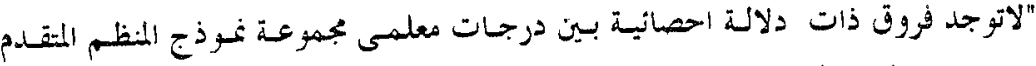

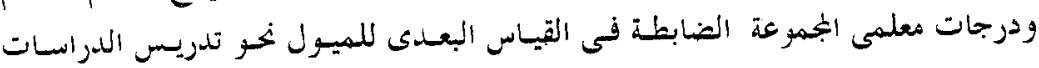

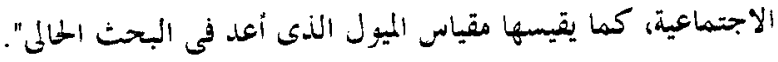




\section{$-657-$}

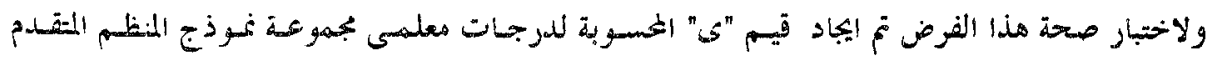

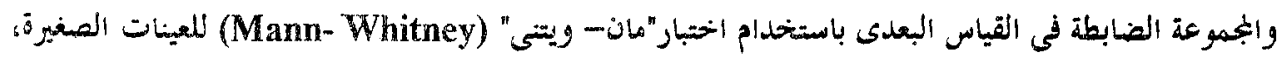

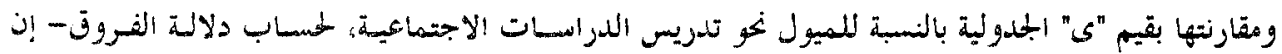

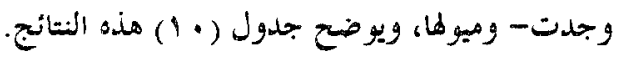

\section{جدول (1.)}

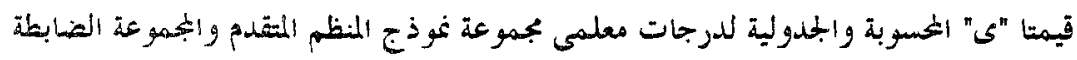

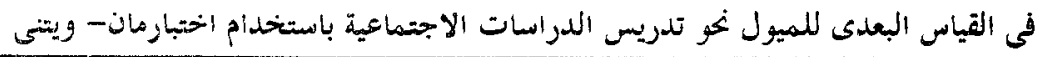

\begin{tabular}{|c|c|c|c|c|c|c|}
\hline اغخوثة & 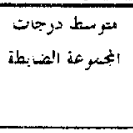 & 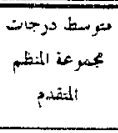 & عسترى الدلالي & 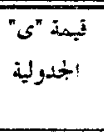 & "ائحسة "ى" & اليان \\
\hline المنظم - المدم & $\Delta V, A T$ & $9 Y, 0$ & دالة & 1 & صفر & الإجـــاعية نحو تلدريس الدراسـات \\
\hline
\end{tabular}

$$
\text { من الجدول السابق يتضح: }
$$

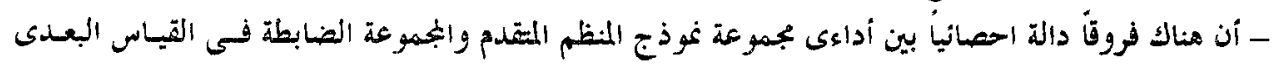

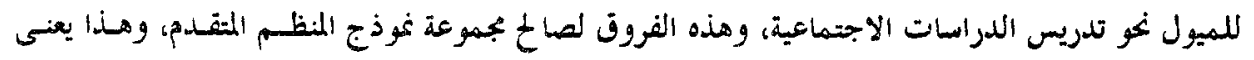

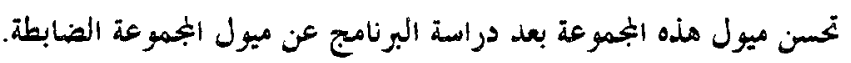

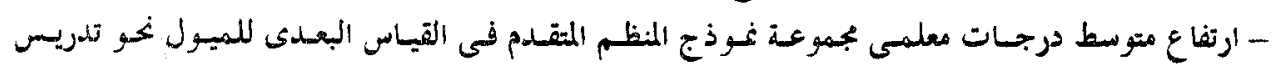

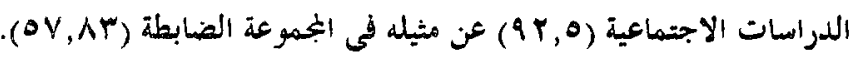

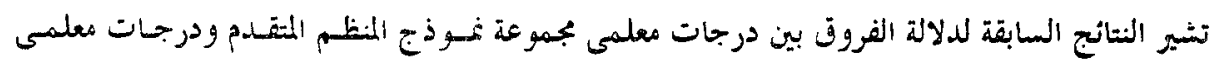

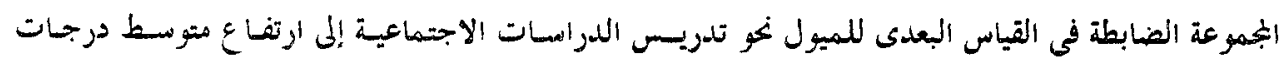

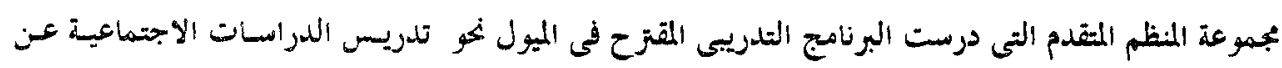

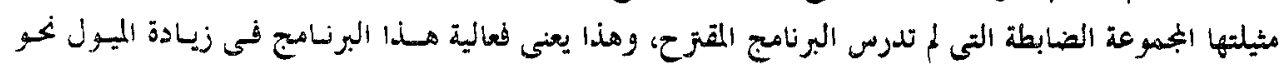

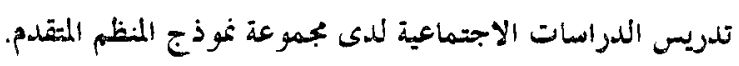

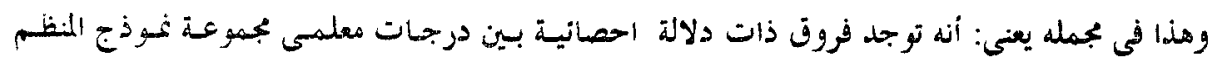

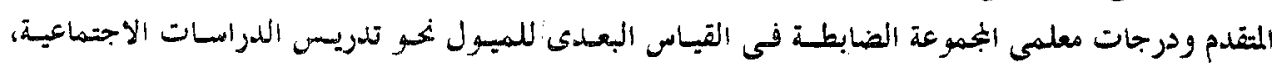

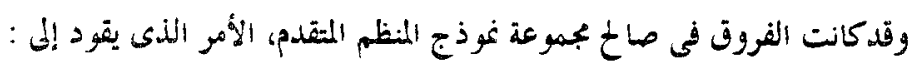

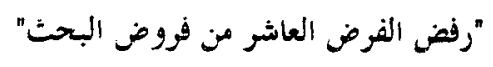

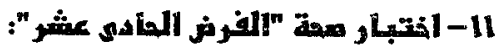

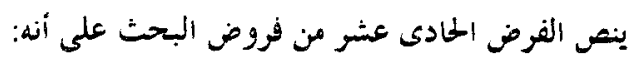

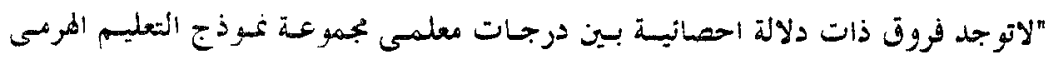

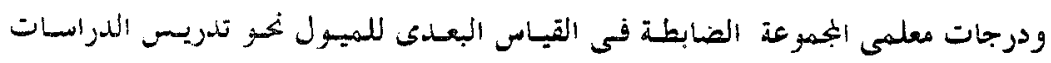

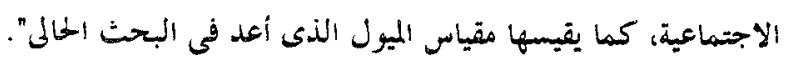




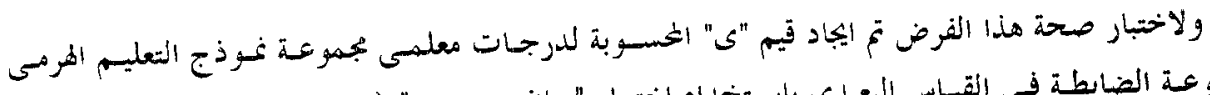

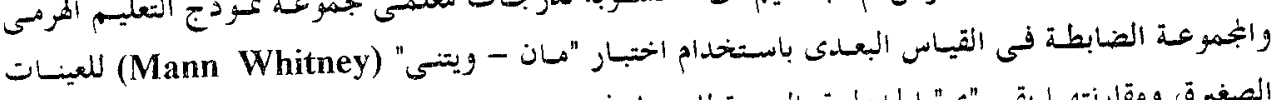

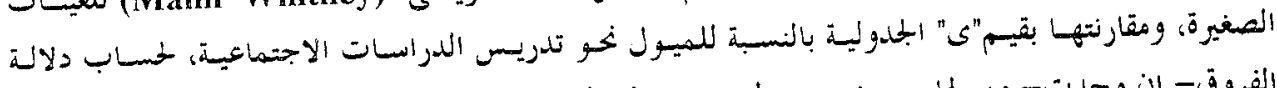

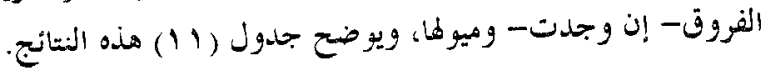

جدول (1)

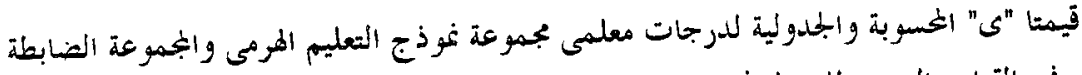

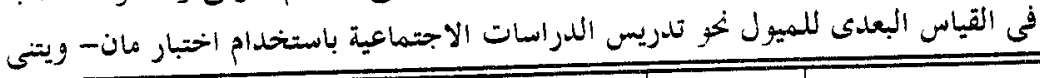

\begin{tabular}{|c|c|c|c|c|c|c|}
\hline 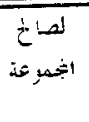 & الخبر عة الضابطنة & بمبرون البعلمي & عند هـ هـ الدلالة & ليسمة "ى" الجدولية & الخسربة "ى" & الييان \\
\hline المرعى & $\Delta V, A T$ & $9 \leq, 9$ & دالة & 。 & صفر & 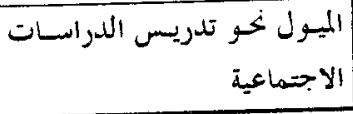 \\
\hline
\end{tabular}

هن الجدول السابق يتضح:

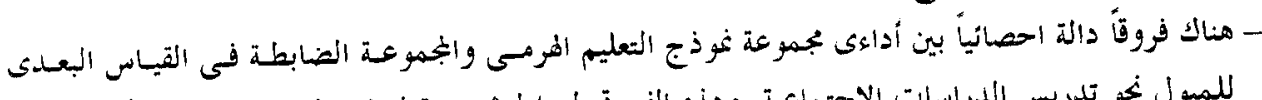

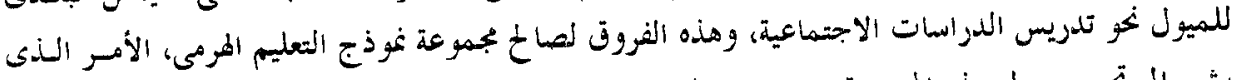

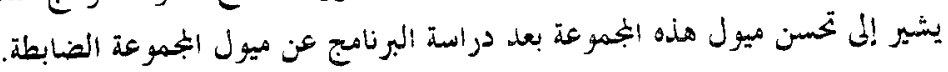

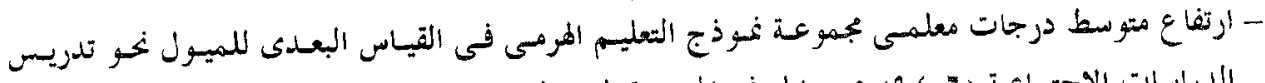

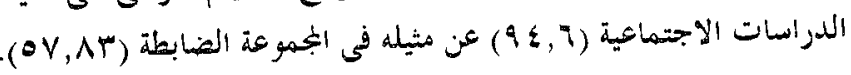

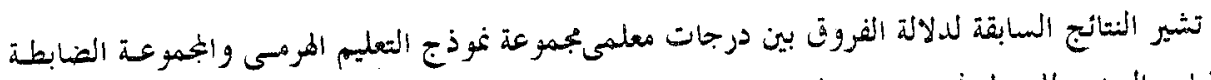

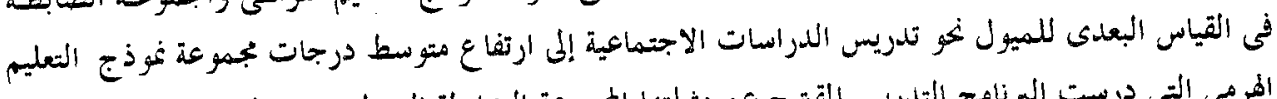

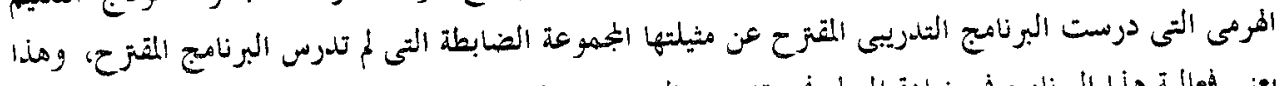

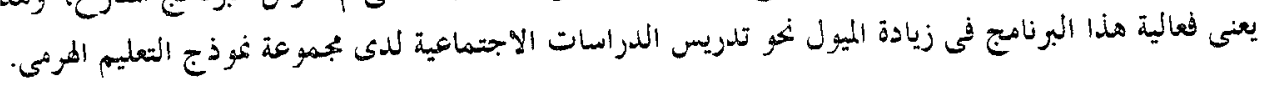

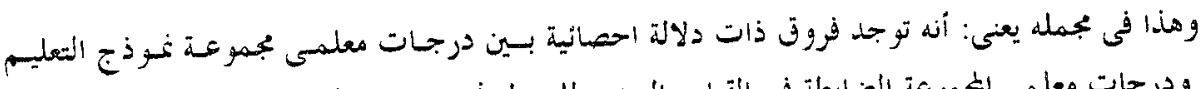

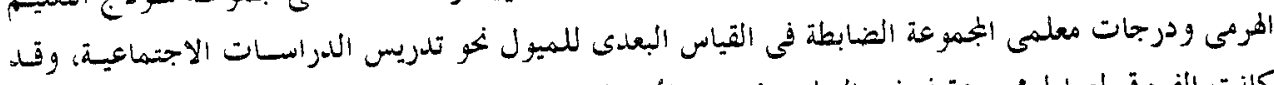

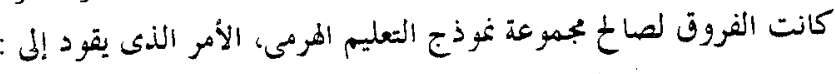

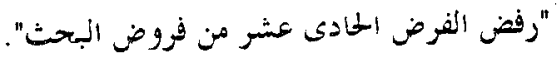

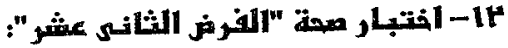

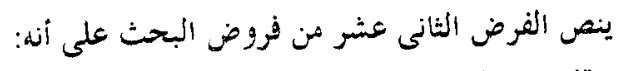

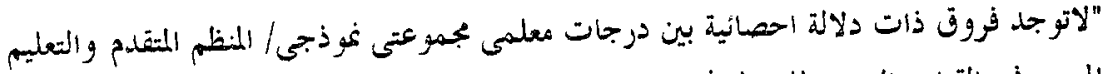

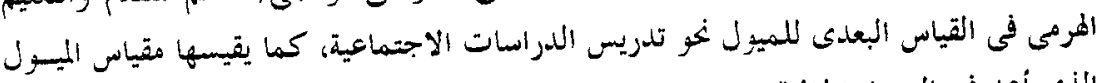

$$
\text { الذى أعد في البحث الحلى". }
$$




\section{$-<2 \pi-$}

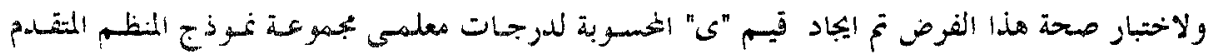

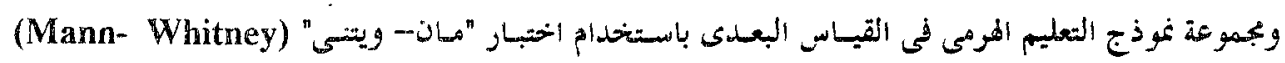

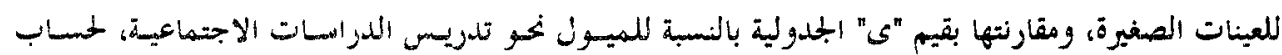

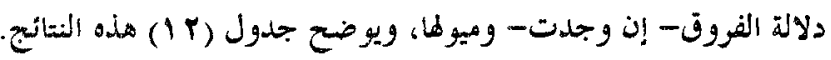

$$
\text { جدول (ir) }
$$

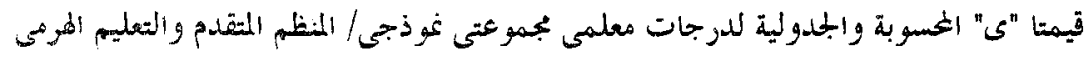

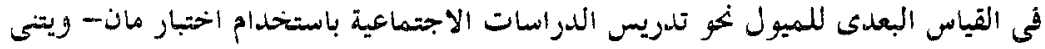

\begin{tabular}{|c|c|c|c|c|c|c|}
\hline الصساخ & 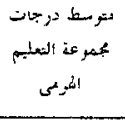 & 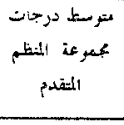 & 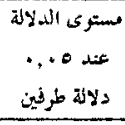 & تيمنة "لئي" & الغيمة "ىى" & الييان \\
\hline & $9 \varepsilon, 7$ & $9 \%, 0$ & غير دالة & $\bullet$ & 11 & 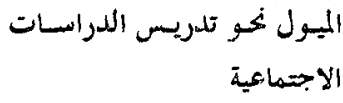 \\
\hline
\end{tabular}

من الجدول السابق يتضح:

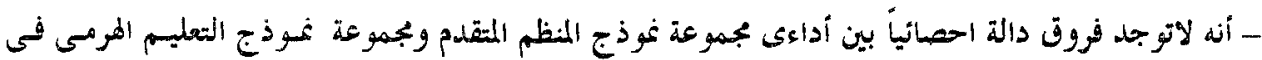

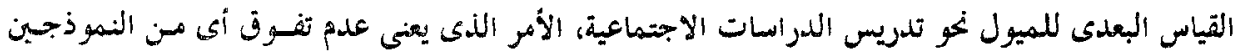
المستخلمين في التأتير على هذا الجيول الجمانب.

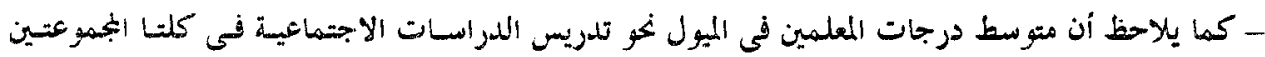

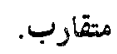

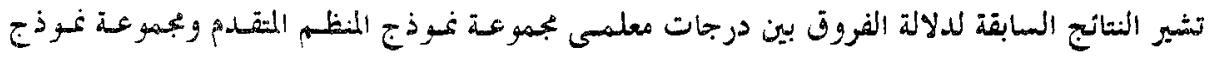

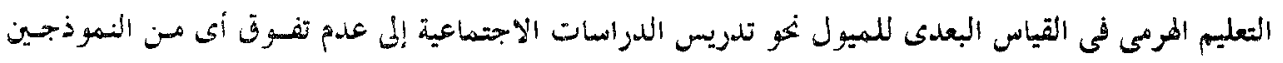

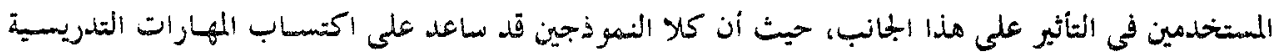

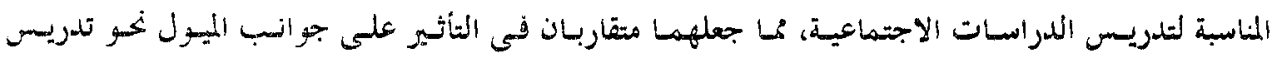

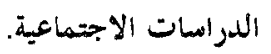

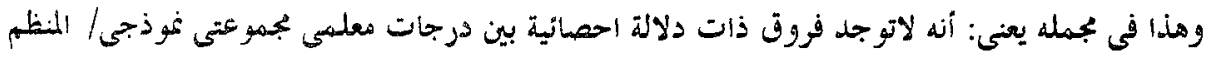

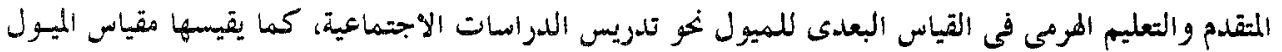

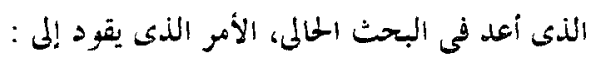

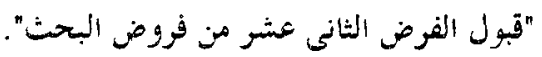




\section{- $589-$}

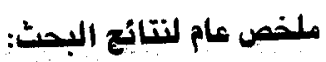

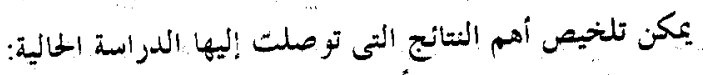

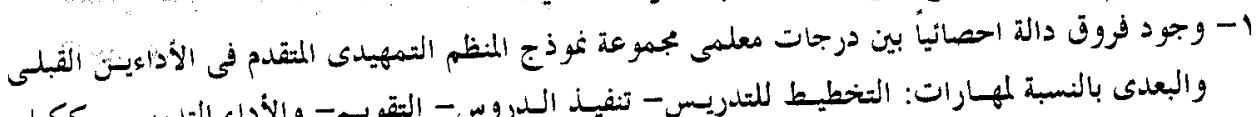

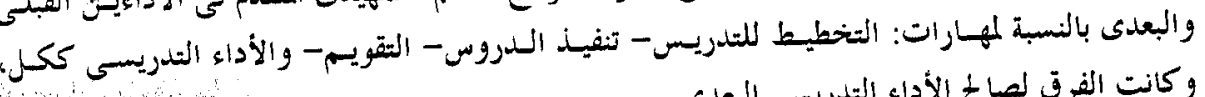
وكانت الفرق لصالح الأداء التدريسى البعلدى اليخطي.

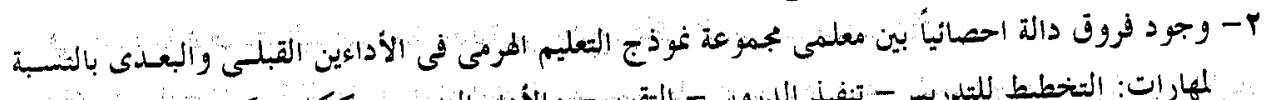

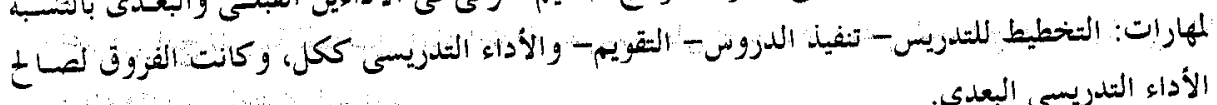

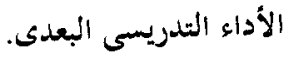

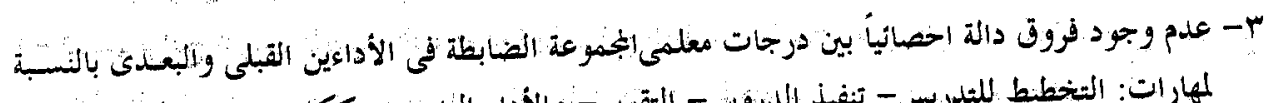

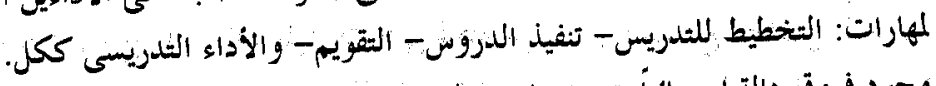

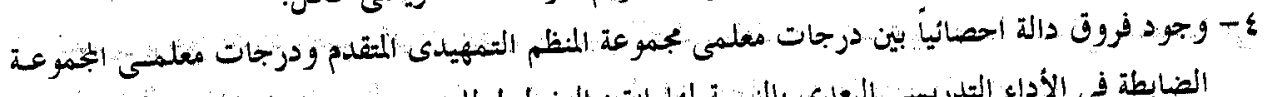

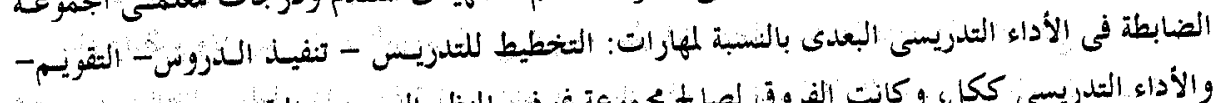

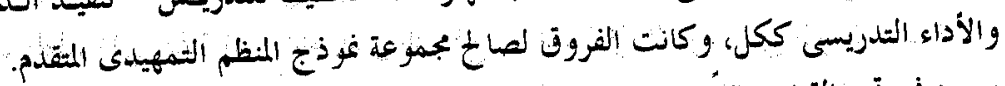

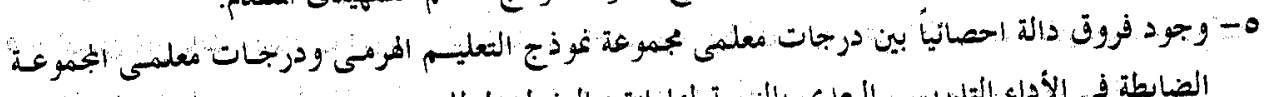

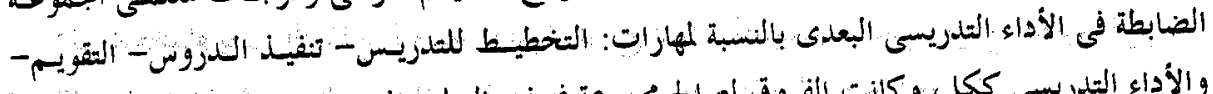

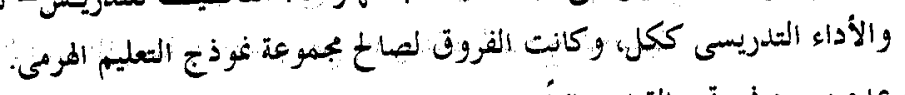

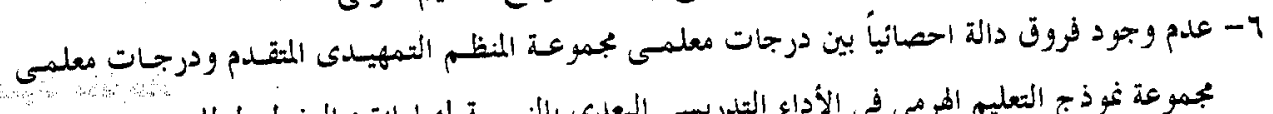

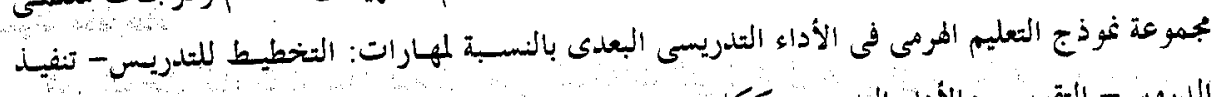
الدروس- التقويم- والأذواء الثدريسى ككل. V- وجود فروق دالة احصائياً بين درجات معلمى مجموعة نموذج المنظم التمهيدى المتقدم في التياسين القبلى

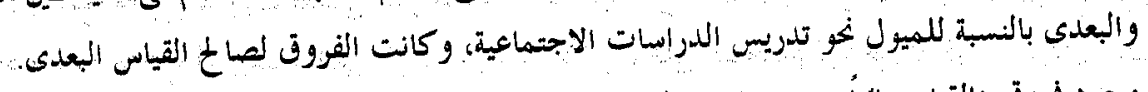

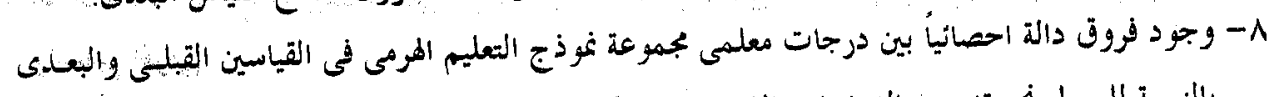

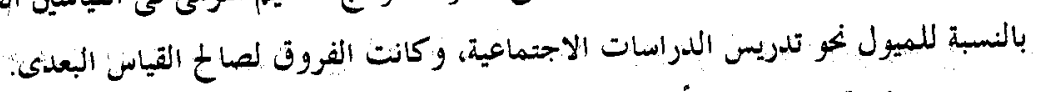

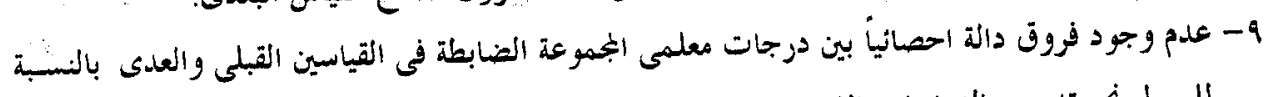
للميول نهو تلدريس الدراسات الاجتماعية.

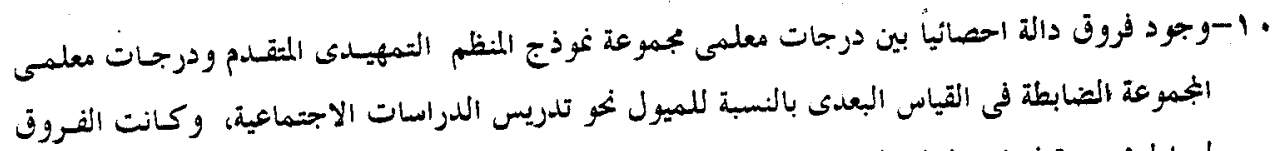

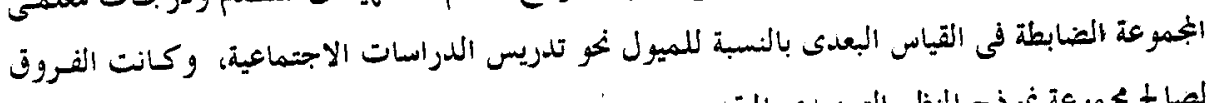

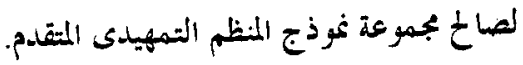

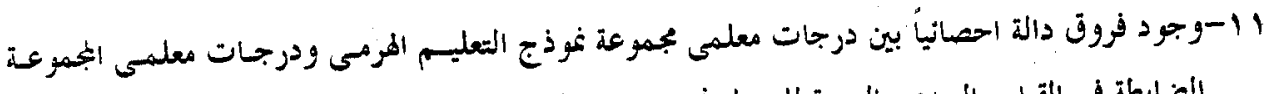

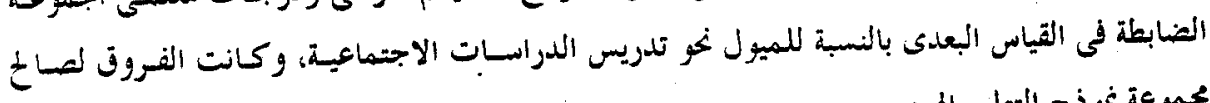

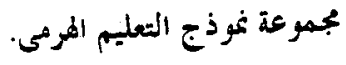




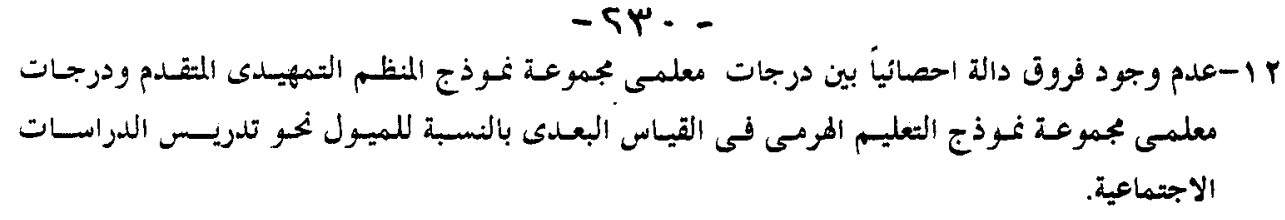

التوصيات والمتنرحات:

في ضوء ما توصلت إليه الدراسة الحالية من نتائج، يمكن تقديم التوصيات الآتية:

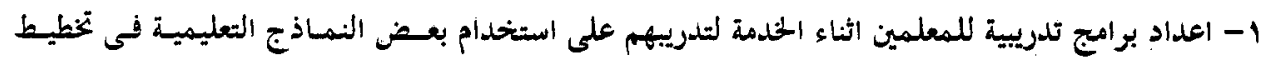

وبناء وتلدريس الخحتوى الدراسى.

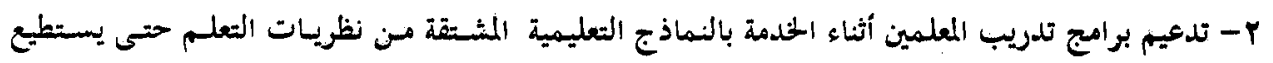

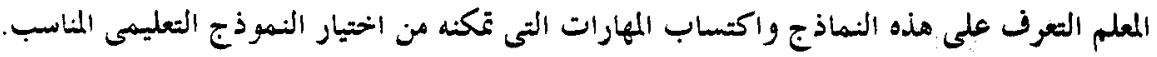

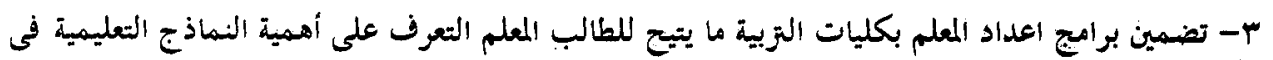

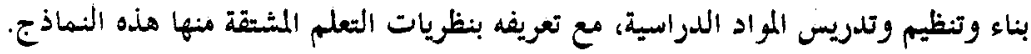

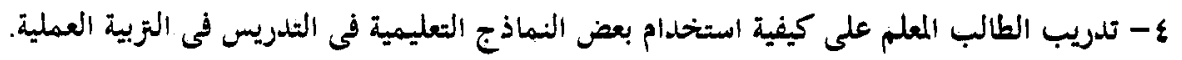

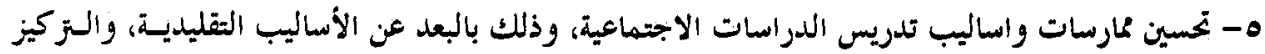

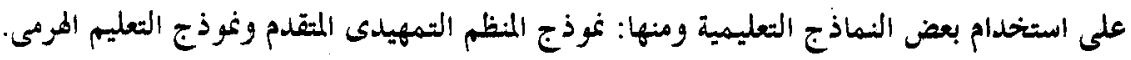

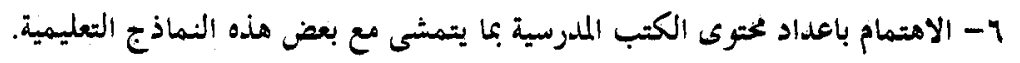

بوث مقترحة:

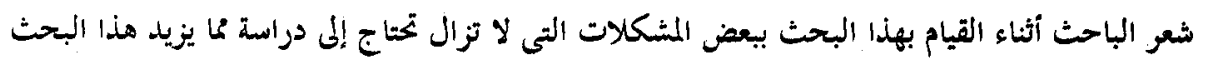

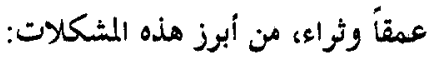

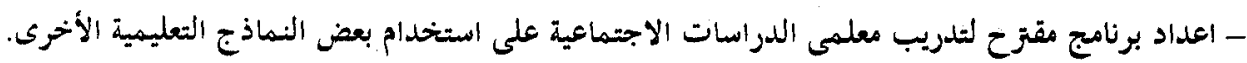

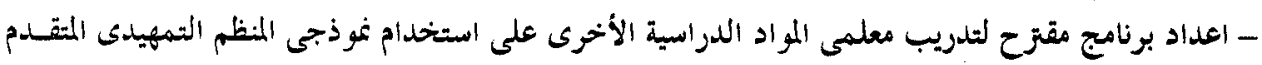

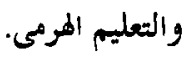

- إجراء بحوث أخرى تتناول المقارنة بين نموذج المنظم التمهيدى المتقدم ونموذج التعليم الهرمى وغاذج تعليميـة أخوى. 


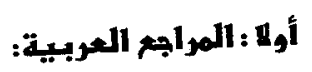

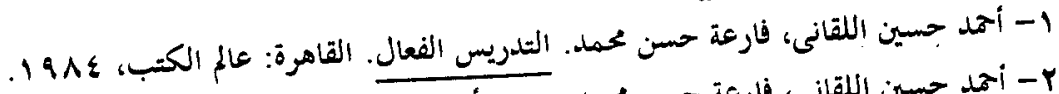

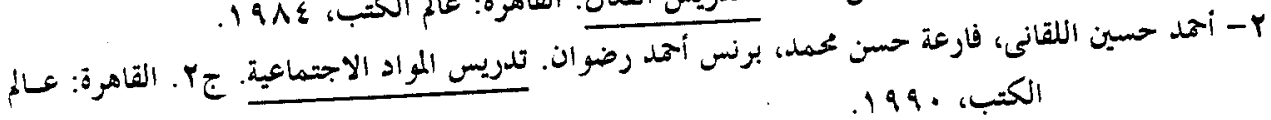
الكتب، . 199. 19.

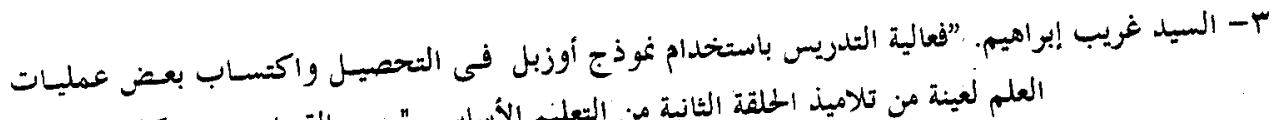

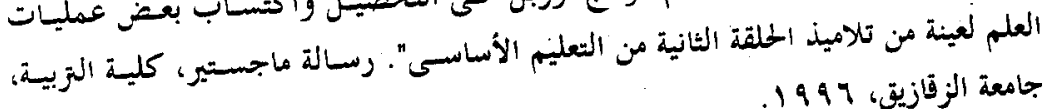

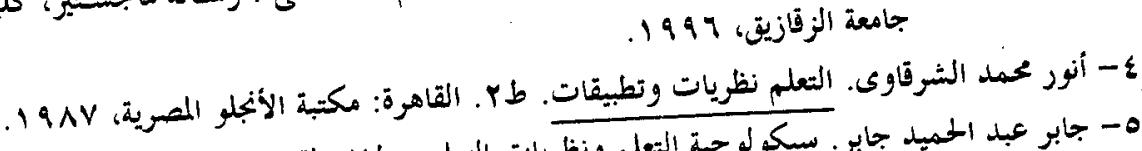

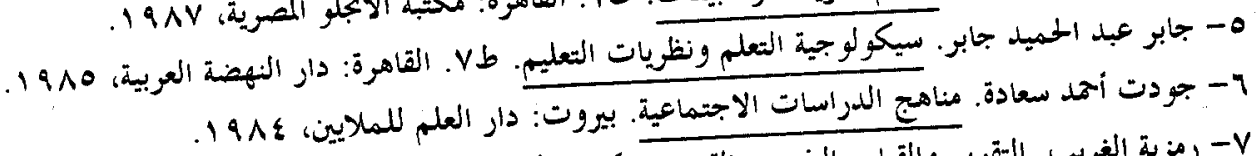

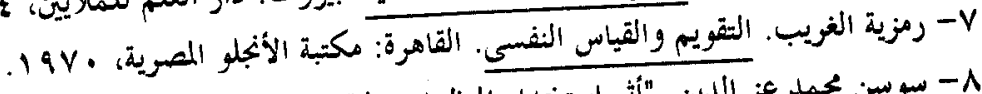

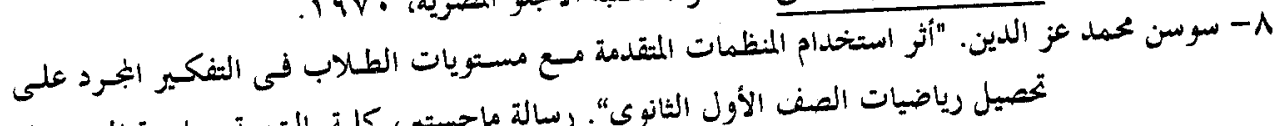

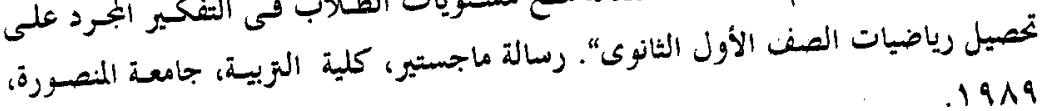

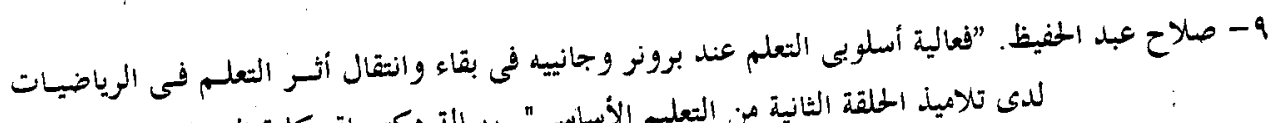

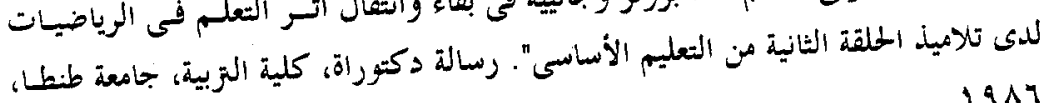

• ا- عادل السيد سرايا. "دراسة التفاعل بين المنظمات المتقدمة والسعة العقلية لدى تلاميذ المرحلة الاعدادية

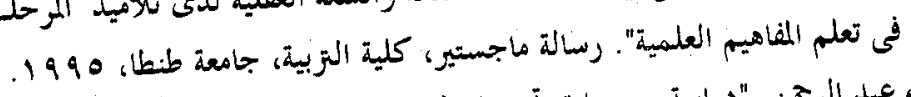

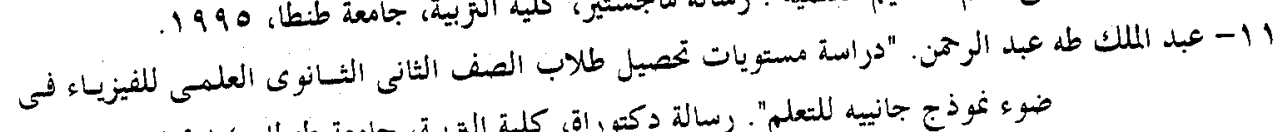

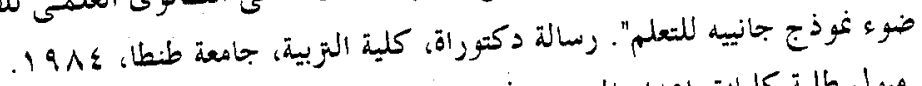

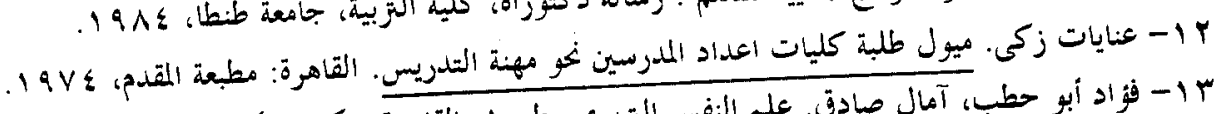

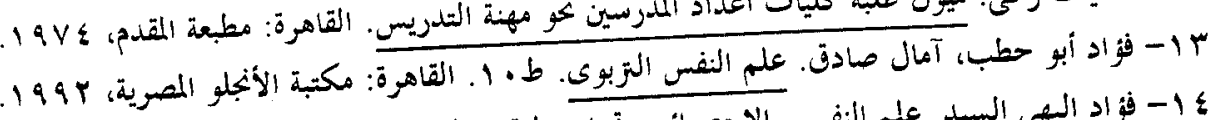

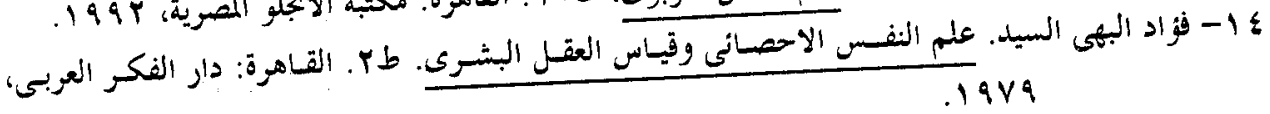

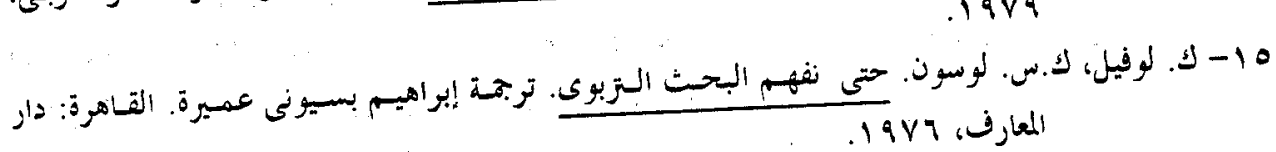
19 - لطفى محمد فطيم، أبو العز ايم عبد المنعم الجمال. نظريات التعلم المعاصرة وتطبيقاتها الزّبويـة. القـاهرة:

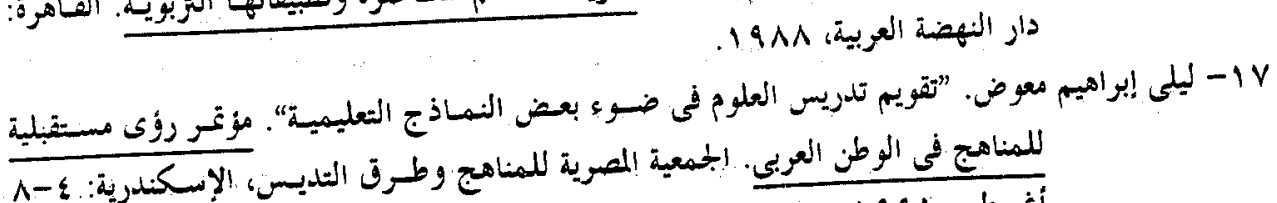

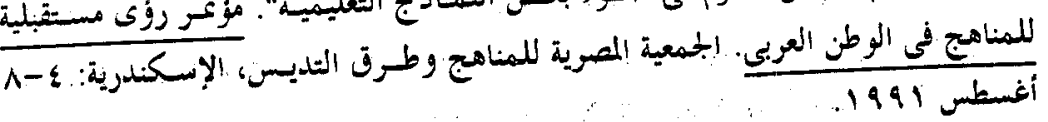




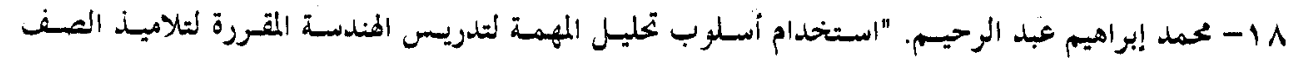

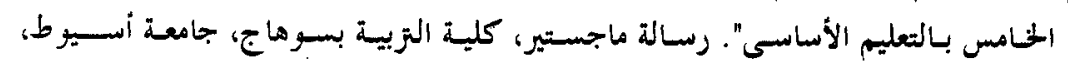

\section{$.19 \wedge \varepsilon$}

9 - 19 محمد أمين المتىى. أثر استخدام تحليل المهمة على ألتحصيل في موضوع الأسس والمجذور. القاهرة: مطبعة

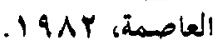

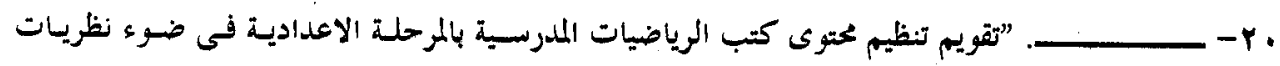

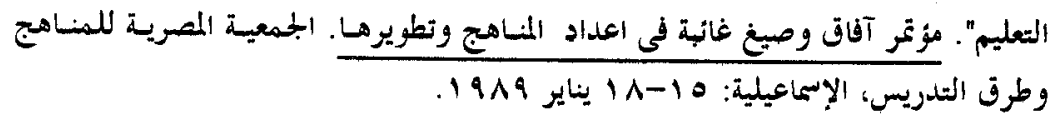

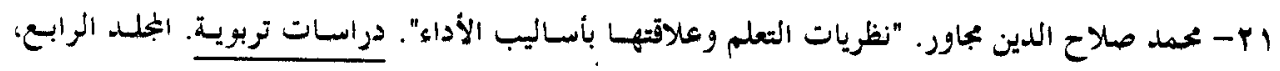

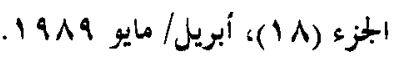

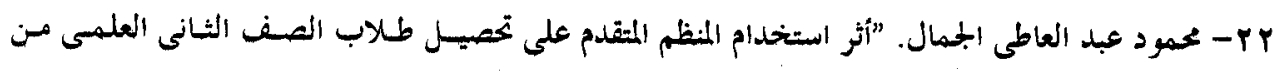

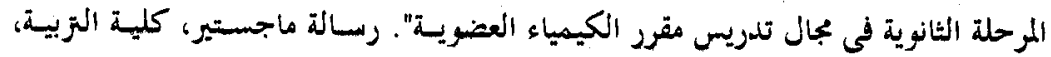

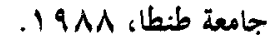

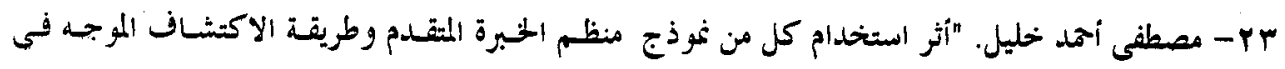

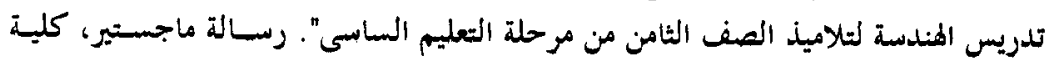

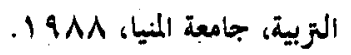

§ ؟- ممدوح عبد المنعم الكنانى، أهمد محمد مبارك الكندرى. سيكلوجية التعلم وأنماط التعليم. الكويت: مكتبسة

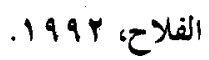

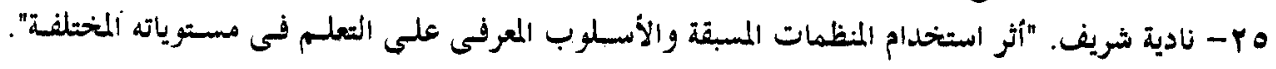

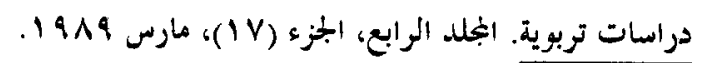

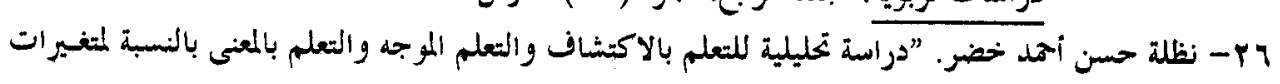

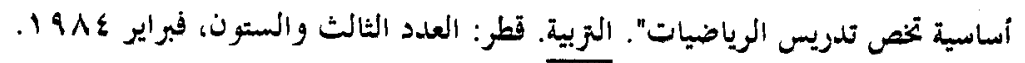

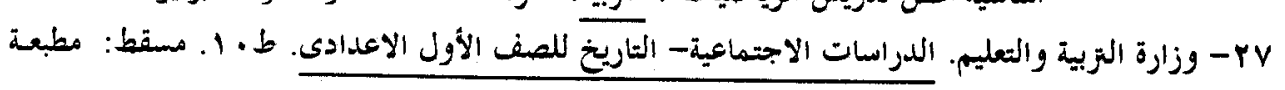

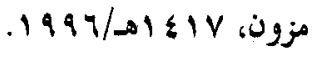

\section{ثانياً:}

28- Allen, D.. "Some Effects of Advance Organizers and Levels of Question on the Learning, Retention of Written Social Studies Material". Journal of Educational Psychology. Vol. 78, No. 5, 1985.

29- Ausubel, D., Novak, M., Mansion, M.. Educational Psychology: A Cognitive View. 2nd. ed. New York: Holt, Rinehart and Winston, Inc., 1978.

30- Barron, R. R.. "The Effects of Advance Organizers of the Reception Learning and Retention of General Science Content". American Educational Research Journal. Vol. 23, No. 3, 1991. 
31- Bassopo- Moyo, Temba C.. "The Effects of Preinstructional Activities in Enhancing Learner Recall and Conceptual Learning of Prose Materials for Preservice Teachers in Zimbabwe". Journal of Educational Psychology. Vol. 89, No. 3, 1996.

32- Boehm, Richard G.. "The Bete Noir of Geographic Education: Teacher Training Programs". Journal of Geography. Vol. 93, No. 1, Jan.Feb. 1994.

33- Bollees, R. C.. Learning Theory. New York: Holt, Rinehart and Winston, 1978.

34- Cohen, Fredric. "Teacher in Training". Executive Educator. Vol. 14, No. 12, Dec. 1992.

35- Egger, P. P.. Strategies for Teachers, Information Processing Models in the Classroom. New York: Prentice- Hall, 1979.

36- Flynn, John L.. "Cooperative Learning and Gagne's Events of Instruction: A Syncretic View". Educational Technology. Vol. 32, No. 10, Oct. 1990.

37- Gagné, R.. The Condition of Learning. 3rd. ed. London: Holt, Rinehart and Winston, Inc., 1977.

38- Griffiths, Alan K.. "High School Students' Understanding of Food Webs: Identification of a Learning Hierarchy and Related Misconceptions". Journal of Research in Science Teaching. Vol. 22, No. 5, May 1985.

39- Hass, Stephanie W.. "A Feasility Study of the Case Hierarchy Model for the Contruiction and Porting of Natural Language Interfaces". Information Processing and Management. Vol. 26, No. 5, 1992.

40- James, Pauline. "Models of Vocational Development Revisited: Reflecting on Concerns". Vocational Aspect of Education. Vol. 47, No. 3, 1995.

41- Joyce, B., Weil, M.. Models of Teaching. New York: Prentice- Hall, 1980.

42- Kahle, J. B., Norland, F. M.. "The Effects of an Advance Organizers When Utilized with Carefully Sequeneced Audio- Tutorial Units". Journal of Research in Science Teaching. Vol. 12, No. 1, 1995.

43- Kjelgaard, Peggy A.. "Teacher Training in the Professional Development Model: Implications for Students at Risk". Computing Teacher. Vol. 21, No. 7, Apr. 1994. 
44- Lawton, J., Wanska, S.. "The Effects Different Types of Advance Organizers and Classification Learning". Journal of Educational Research. Vol. 26, No. 3, 1989.

45- Lenz, B. Keith, Deshler, Donald D.. "Principles of Strategies Instruction as the Basis of Effective Preservice Teacher Education". Teacher Education and Special Education. Vol. 13, N. 2, Spr. 1990.

46- Patterson, C. H.. Foundations for a Theary of Instruction and Educational Psychology. New York: Harper and Row, 1977.

47- Platten, Marvin. "Teaching Concepts and Skills of Thinking Simultaneously". Journal of Educational Issues of Language Minority Students. Vol. 9, Fall 1991.

48- Romberg, T., Wilson, J.. "The Effects of an Advance Organizers, Cognitive Set and Past Organizers of the Learning and Retention of Written Materials". Journal of Research in Mathematics Education. Vol. 26, No. 1, 1990.

49- Sklare, Gerald.. "Developing Questioning Effectivenss in Counseling". Counselor Education and Supervision. Vol. 25, No. 1, Sep. 1985.

50- Spinelli, Emily, Siskin, Jay H.. "Activating the Reading Skill Through Advanced Organizers". Canadian Modern Language Review. Vol. 44, No. 1, Oct. 1987.

51- Taylor, Harriet G.. "The Use of Team Projects to Teach Computer Science Concepts and Teaching Methodologies". Journal of Computers in Mathematics and Science Teaching. Vol. 13, No. 2, 1994. 